University of Rhode Island

DigitalCommons@URI

Open Access Dissertations

2019

\title{
TOWARDS SUSTAINABLE MANAGEMENT OF THE SARDINELLA FISHERY IN GHANA
}

Evans Kwasi Arizi

University of Rhode Island, evansarizi@uri.edu

Follow this and additional works at: https://digitalcommons.uri.edu/oa_diss

\section{Recommended Citation}

Arizi, Evans Kwasi, "TOWARDS SUSTAINABLE MANAGEMENT OF THE SARDINELLA FISHERY IN GHANA" (2019). Open Access Dissertations. Paper 898.

https://digitalcommons.uri.edu/oa_diss/898

This Dissertation is brought to you for free and open access by DigitalCommons@URI. It has been accepted for inclusion in Open Access Dissertations by an authorized administrator of DigitalCommons@URI. For more information, please contact digitalcommons-group@uri.edu. 


\section{TOWARDS SUSTAINABLE MANAGEMENT OF THE SARDINELLA FISHERY \\ IN GHANA}

BY

EVANS KWASI ARIZI

A DISSERTATION SUBMITTED IN PARTIAL FULFILLMENT OF THE REQUIREMENTS FOR THE DEGREE OF DOCTOR PHILOSOPHY

IN

BIOLOGICAL AND ENVIRONMENTAL SCIENCES

UNIVERSITY OF RHODE ISLAND 


\section{DOCTOR OF PHILOSOPHY DISSERTATION}

OF

EVANS KWASI ARIZI

\section{APPROVED:}

Dissertation Committee:

Major Professor

Austin T. Humphries

Jeremy Collie

Kathleen Castro

Nasser H. Zawia

DEAN OF THE GRADUATE SCHOOL, URI

UNIVERSITY OF RHODE ISLAND 


\begin{abstract}
Many local fishermen in Ghana depend on the sardinella fishery for their livelihoods. Flat sardinella (Sardinella maderensis) and round sardinella (Sardinella aurita) are the two main fish species that are exploited in the fishery. Landings of the sardinella stocks, however, have been declining for over a decade now as a result of overfishing engendered by overcapacity, open access fishery and weak governance. The focus of this work was to chart the path towards a sustainable management of the fishery in Ghana by identifying the key extractive components of the fishery, ascertaining the interactions among them and the fish stocks and using the life history of the fish to simulate their population dynamics under different scenarios of seasonal closures in conjunction with gear restrictions so as to arrive at the optimal management strategy.

Manuscript I: The goal of this study was to describe the basic fisher and catch characteristics as a first step in understanding the fishery and setting the basis for management decisions. We sampled 8 sites along the coast of Ghana from 2017-2018 and collected data on over 14,000 individuals of sardinellas from 332 unique fishing trips. We found three broad categories of fishing gears: beach seines, purse seines and gill nets. Three types of purse seines were identified and distinguished based on mesh sizes: poli $\leq 3.0 \mathrm{~cm}$; watsa $>3.0 \mathrm{~cm}$; and poli-watsa had a combination of mesh sizes. Differentiation of gill nets was based on either monofilament (called "set net") or cotton (called "ali"). Poli-watsa constituted the most dominant gear in the fishery. Two species of sardinella were captured, the round (Sardinella aurita) and the flat (Sardinella maderensis) sardinella. Ninety-six percent of the vessels were motorized. The landings were predominantly juveniles. Considering the dominance of juveniles in the landings
\end{abstract}


of the sardinella fishery in Ghana, management that reduces effort using specific gears or eliminates fishing during certain times of the year could be effective.

Manuscript II: Sardinella stocks made up of flat sardinella (Sardinella maderensis) and round sardinella (Sardinella aurita) form the mainstay of the artisanal fisheries of Ghana. The landings of these stocks, however, have been dominated by small, immature fish in recent years. Yet, no comprehensive assessment has been conducted to identify the fishing gears that unsustainably harvest juvenile fish and what factors drive their distribution. In this study, we examined the distribution of sardinella species in the Ghanaian fishery and used length at first sexual maturity $\left(L_{m}\right)$ of the fish as a reference point to determine the composition of the catches for each gear type and season. S. maderensis preferred coastal waters up to $65 \mathrm{~m}$ in depth, whereas $S$. aurita inhabited waters of depth up to $500 \mathrm{~m} . S$. maderensis matured at $15.3 \mathrm{~cm}( \pm 0.013$, $\mathrm{N}=1,777)$, which was greater than $S$. aurita at $14.2 \mathrm{~cm}( \pm 0.004, \mathrm{~N}=2,684)$. Recruitment of young fish into the sardinella stocks occurred throughout the year. Fishers used different gears to catch a wide variety of sizes of the two sardinella species at different depths and in different seasons. The average probability of capturing immature fish per each gear type was: beach seine $(68 \%)>$ poli $(46 \%)>$ set net $(43 \%)>$ ali $(22 \%)>$ watsa (4\%). In other words, ali and watsa fishers were catching the majority of their fish above $L_{m}$. Fishers using poli, poli-watsa, beach seine and set net, however, were generally harvesting individuals below $L_{m}$ suggesting that more juveniles are harvested by poli, poli-watsa, beach seine users in Ghana. These findings provide a baseline to encourage an increase in mesh sizes of poli, poli-watsa, beach seine and set net to a minimum size of $2.5 \mathrm{~cm}$ as a management tool to complement the ongoing seasonal closure in Ghana. 
Manuscript III: The sardinella fishery forms the backbone of Ghana's marine artisanal fisheries. There are two species in the sardinella fishery: flat sardinella (Sardinella maderensis) and round sardinella (Sardinella aurita). Catches of these fish, however, have been dwindling for the last decade due to overfishing. Yet, little research has been done to guide or inform the government of Ghana on possible outcomes from different fisheries management strategies. Hence, this study sought to explore two potential management solutions to achieve sustainable exploitation rates of the sardinella stocks. First, we determined the life-history characteristics of S. maderensis (7, 240 individuals) and of $S$. aurita $(6,848$ individuals). We then simulated the population dynamics of both species under different seasonal fishing closures, with and without accompanying gear restrictions. The population growth rates of the two sardinella species ranged from $0.089-2.59 \mathrm{yr}^{-1}$ under seasonal closures without gear restrictions, as well as under seasonal closures with gear restrictions. Growth rates, however, were relatively higher under the seasonal closures with gear restrictions as compared to the seasonal closures without gear restrictions due to high recruitment of juveniles into the fishery. Although longer seasonal closures resulted in higher population growth rates, we found that a one-month seasonal closure with gear restrictions to be the optimal management strategy. The gear restrictions would allow the fish to spawn at least once in their lifetime before they become harvestable. Under the current management status quo, our results suggest that both species will continue to dwindle and collapse within $15-20$ years. These simulations provide managers with the tools necessary to forecast sardinella populations in Ghana under different policies, enabling sustainable management regulations to be established. 


\section{ACKNOWLEDGEMENTS}

I wish to express my profound gratitude to my major professor, Austin $\mathrm{T}$. Humphries, for the guidance, mentorship, swift and timely feedback he provided for me. I am also grateful to Professor Jeremy Collie for the great support, constructive criticism and for giving me the opportunity to study under his tutelage. Special thanks to Dr. Kathleen Castro for the words of encouragement and for the hope she constantly restored in me throughout my studies. Many thanks are due to USAID for funding my studies through the USAID/Ghana Sustainable Fisheries Management Project (SFMP) implemented by the Coastal Resources Center (CRC) of the University of Rhode Island (URI).

I also thank Dr. Brian Crawford, Mr. Najih Lazar and Madam Kim Kaine, all of CRC, for facilitating my travel from Ghana to USA for the PhD program. The great logistical support provided by the Department of Fisheries and Aquatic Sciences (DFAS) of the University of Cape Coast (UCC) during my fieldwork in Ghana is highly appreciated. I am also indebted to Professor Denis W. Aheto of UCC for his active role in facilitating my travel to URI for the PhD studies and for his words of encouragement and motivation. I also thank Maximillian Bucher for providing some degree of assistance at the early stages of my fieldwork. Many thanks to my lab members for creating the conducive environment to facilitate my studies; I specially thank Lauren Josephs for being supportive to me throughout my studies. To my family, I am very thankful for your prayers and patience throughout my program elsewhere in USA; I am most grateful to my wife, Marian for her prayers, patience, motivation and encouragement and for taking care of my children, Dominique and Denis in my absence. 
PREFACE

This dissertation is written in the manuscript format specified by the Graduate School of the University of Rhode Island

Manuscript I is written for the Fisheries Research and it will be submitted for review upon successful completion of this dissertation.

Manuscript II is written for Marine Ecology Progress Series and it will be submitted for review upon successful completion of this dissertation.

Manuscript III is written for PLoS ONE and it will be submitted for review upon successful completion of this dissertation. 


\section{TABLE OF CONTENTS}

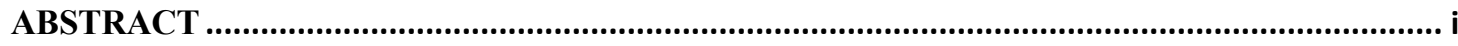

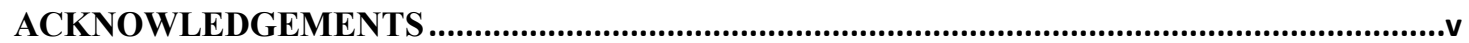

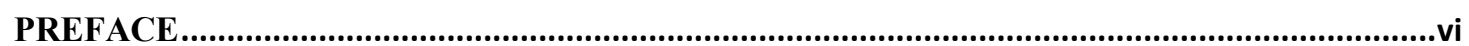

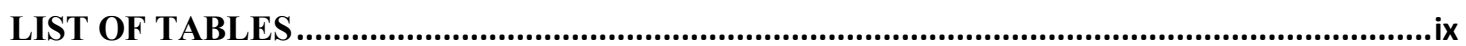

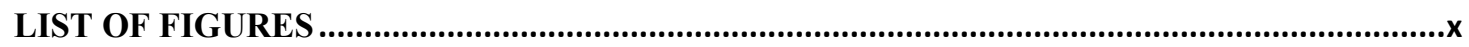

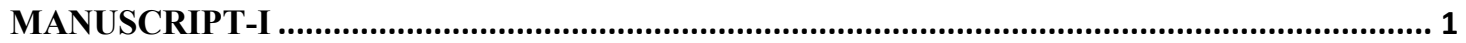

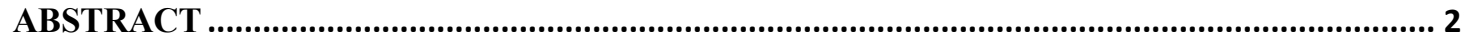

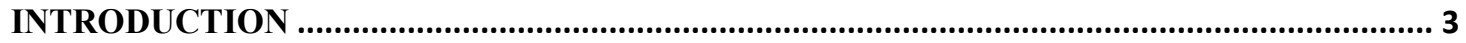

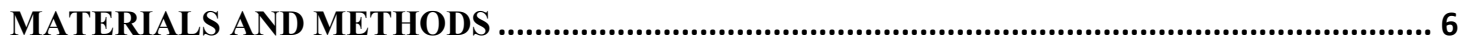

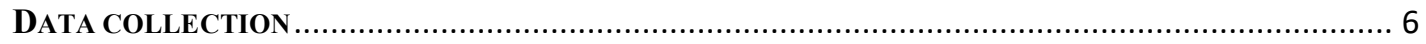

DATA ANALYSIS

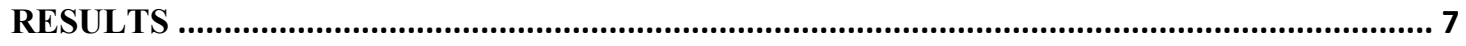

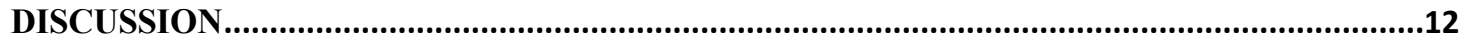

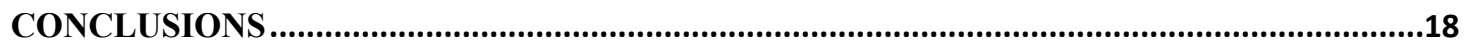

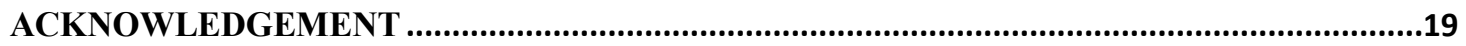

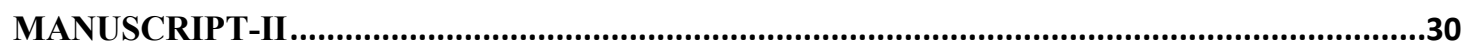

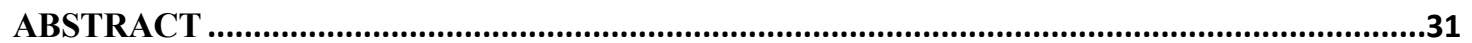

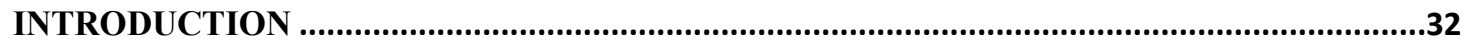

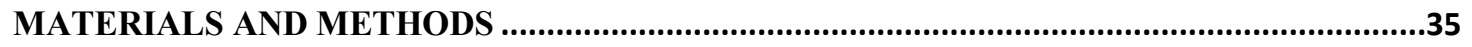

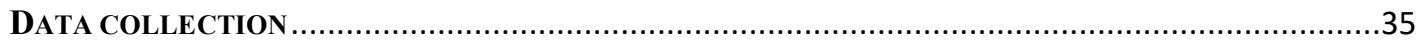

DATA ANALYSIS

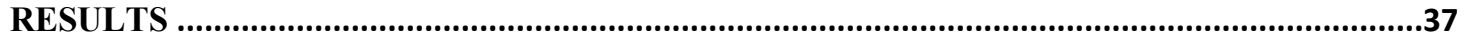

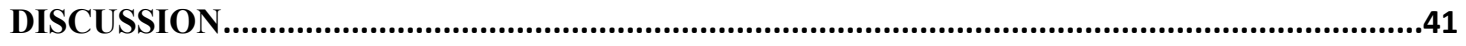

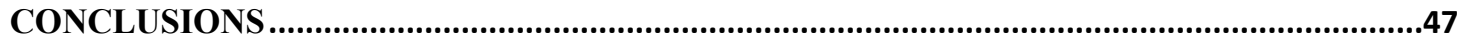

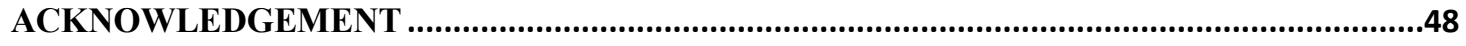

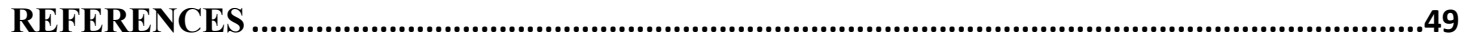

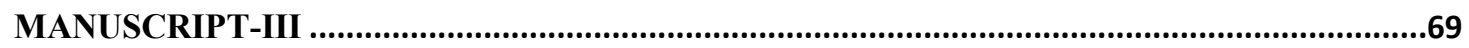

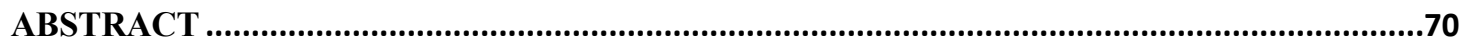

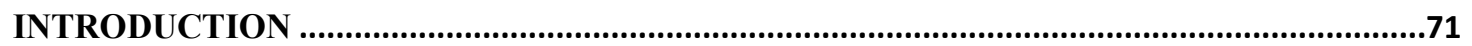

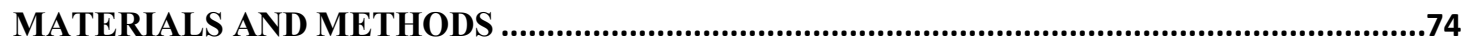

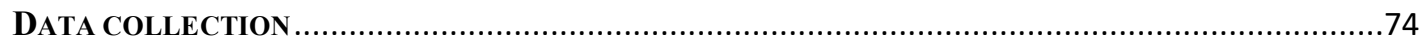

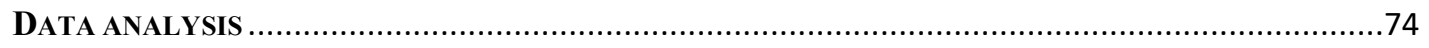

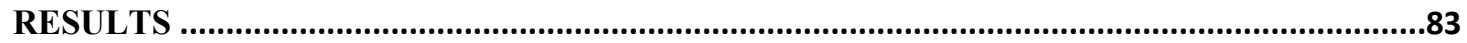

DISCUSSION

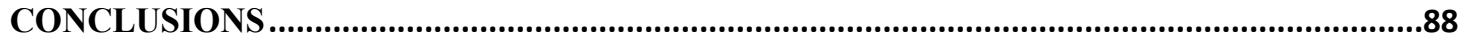




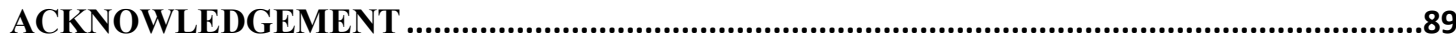

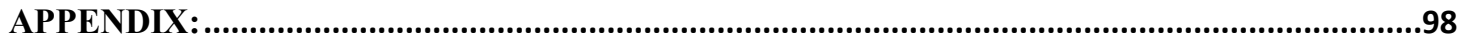




\section{LIST OF TABLES}

Table 1. ANOVA table showing statistical differences in the total lengths of Sardinella maderensis and Sardinella aurita among different depths of fishing locations in coastal waters of Ghana. .65

Table 2. Modal length of fish in the catch of each fishing gear ................................66

Table 3. Modal length of fish in the catch per season .......................................67

Table 4. ANOVA table showing the effects of gears, period of exploitation and depth of fishing location with their interaction effects on the total length of Sardinella maderensis and of Sardinella maderensis in the landings of the sardinella fishery of

Ghana 68

Table A1. The growth, mortality and reproductive parameters of flat sardinella and round sardinella in the coastal waters of Ghana ................................................. 98

Table A2. Life history table of flat sardinella in the coastal waters of Ghana.............99

Table A3. Life history table of round sardinella in the coastal waters of Ghana....... 100

Table A4. Archetype of the projection matrix for the closed season scenario, $\left(\boldsymbol{M}_{\boldsymbol{x} / \mathbf{1 2}}\right)$ commencing at time $t$ 101

Table A5. Archetype of the projection matrix for the fishing season scenario, $\left(\boldsymbol{M}_{12-x / 12}\right)$ which was assumed to follow the fishing closure immediately at time $t+x / 12 \ldots \ldots . .101$ 


\section{LIST OF FIGURES}

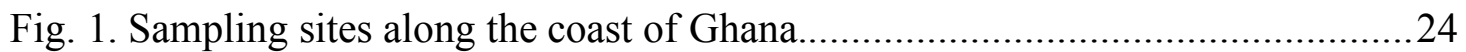

Fig. 2. Percent composition of fishing gears in the sardinella fishery of Ghana..........25

Fig. 3. Length of fishing vessels (A), crew size (B), fishing duration (C) and length of fishing nets (D), depth of fishing location (E), mesh size (F) of the various gears in the sardinella fishery of Ghana. Outliers data points are not shown. Red line indicates the legal mesh size of $2.5 \mathrm{~cm}$ enshrined in the Fisheries Act of Ghana ..........................26

Fig. 4. Correlation between some key attributes in the sardinella fishery of Ghana....27

Fig. 5. Length-frequency distributions of (a) flat sardinella and (b) round sardinella in the marine fisheries of Ghana. Red lines indicate the length at sexual maturity for flat

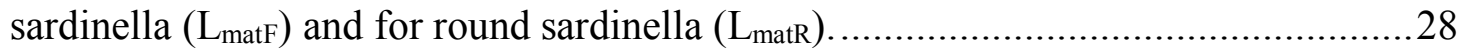

Fig. 6. Catch composition of flat and round sardinellas for each fishing gear in the marine fisheries of Ghana.

Fig. 7. Relationship between depth of fishing location and occurrence of (A) $S$. maderensis and (B) S. aurita within the coastal waters of Ghana.............................57

Fig. 8. Length-based proportions of sexual maturity for (A) S. maderensis and (B) $S$.

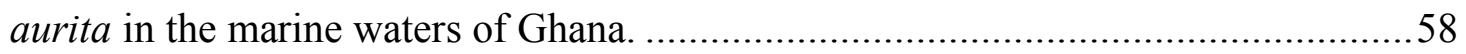

Fig. 9. Length-frequency distributions of sardinella caught by the various gears in the marine fisheries of Ghana. .59

Fig. 10. Bi-monthly length-frequency distributions of flat sardinella and round sardinella in the marine fisheries of Ghana. .60

Fig. 11. Proportions of mature and immature fish per gear type in the sardinella fishery of Ghana. 61 
Fig. 12. Proportions of mature and immature fish per fishing season in the sardinella fishery of Ghana.

Fig. 13. Bi-monthly mean size of $S$. maderensis and $S$. aurita landed per each kind of fishing gear in the marine fisheries of Ghana. Red line represents length at sexual maturity (Lm)

Fig. 14. Selection curves for the various types of fishing nets excluding poli-watsa in the sardinella fishery of Ghana. (F) denotes flat sardinella whereas (R) represents round sardinella. Black dotted lines indicate length at first sexual maturity $\left(L_{m}\right)$ 64

Fig. 15. Landings of sardinellas in Ghana since 1963 (FAO, 1989; 2016). 95

Fig. 16. Population size of $S$. maderensis projected over a 10-year period under: (A) closed season without any gear restrictions scenario; (B) closed season with gear restrictions scenario. MSR stands for mesh size regulation expressed as exclusion from the analysis the fishing mortalities of fish at age 0 . .96 Fig. 17. Population size of S. aurita projected over a 10-year period under: (A) closed season without any gear restrictions scenario; (B) closed season with gear restrictions scenario. MSR stands for mesh size regulation expressed as exclusion from the analysis the fishing mortalities of fish at age 0 .

Fig. A18. Sardinella maderensis projection matrix with the sensitivities and elasticities for the fertility and survival rates of the fish for the status quo scenario..... .102 Fig. A19. Sardinella maderensis projection matrix with the sensitivities and elasticities for the fertility and survival rates of the fish for the 1-month closure without any gear restrictions. 103 
Fig. A20. Sardinella maderensis projection matrix with the sensitivities and elasticities for the fertility and survival rates of the fish for the 2-month closure without any gear restrictions. 104

Fig. A21. Sardinella maderensis projection matrix with the sensitivities and elasticities for the fertility and survival rates of the fish for the 3-month closure without any gear restrictions. 105

Fig. A22. Sardinella maderensis projection matrix with the sensitivities and elasticities for the fertility and survival rates of the fish for the 4-month closure without any gear restrictions. 106

Fig. A23. Sardinella maderensis projection matrix with the sensitivities and elasticities for the fertility and survival rates of the fish for the 5-month closure without any gear restrictions. 107

Fig. A24. Sardinella maderensis projection matrix with the sensitivities and elasticities for the fertility and survival rates of the fish for the 6-month closure without any gear restrictions. 108 Fig. A25. Sardinella maderensis projection matrix with the sensitivities and elasticities for the fertility and survival rates of the fish for the 7-month closure without any gear restrictions.

Fig. A26. Sardinella maderensis projection matrix with the sensitivities and elasticities for the fertility and survival rates of the fish for the 8-month closure without any gear restrictions. 110 
Fig. A27. Sardinella maderensis projection matrix with the sensitivities and elasticities for the fertility and survival rates of the fish for the 9-month closure without any gear restrictions.

Fig. A28. Sardinella maderensis projection matrix with the sensitivities and elasticities for the fertility and survival rates of the fish for the 10-month closure without any gear restrictions.

Fig. A29. Sardinella maderensis projection matrix with the sensitivities and elasticities for the fertility and survival rates of the fish for the 11-month closure without any gear restrictions. .113

Fig. A30. Sardinella maderensis projection matrix with the sensitivities and elasticities for the fertility and survival rates of the fish for the 1-month closure with gear restrictions.

Fig. A31. Sardinella maderensis projection matrix with the sensitivities and elasticities for the fertility and survival rates of the fish for the 2-month closure with gear restrictions. 115 Fig. A32. Sardinella maderensis projection matrix with the sensitivities and elasticities for the fertility and survival rates of the fish for the 3-month closure with gear restrictions. .116 Fig. A33. Sardinella maderensis projection matrix with the sensitivities and elasticities for the fertility and survival rates of the fish for the 4-month closure with gear restrictions. 
Fig. A34. Sardinella maderensis projection matrix with the sensitivities and elasticities for the fertility and survival rates of the fish for the 5-month closure with gear restrictions. 118

Fig. A35. Sardinella maderensis projection matrix with the sensitivities and elasticities for the fertility and survival rates of the fish for the 6-month closure with gear restrictions.

Fig. A36. Sardinella maderensis projection matrix with the sensitivities and elasticities for the fertility and survival rates of the fish for the 7-month closure with gear restrictions. 120

Fig. A37. Sardinella maderensis projection matrix with the sensitivities and elasticities for the fertility and survival rates of the fish for the 8-month closure with gear restrictions.

Fig. A38. Sardinella maderensis projection matrix with the sensitivities and elasticities for the fertility and survival rates of the fish for the 9-month closure with gear restrictions. 122

Fig. A39. Sardinella maderensis projection matrix with the sensitivities and elasticities for the fertility and survival rates of the fish for the 10-month closure with gear restrictions.

Fig. A40. Sardinella maderensis projection matrix with the sensitivities and elasticities for the fertility and survival rates of the fish for the 11-month closure with gear restrictions.

Fig. A41. Sardinella aurita projection matrix with the sensitivities and elasticities for the fertility and survival rates of the fish for the status quo scenario. .125 
Fig. A42. Sardinella aurita projection matrix with the sensitivities and elasticities for the fertility and survival rates of the fish for the 1-month closure without any gear restrictions. 126

Fig. A43. Sardinella aurita projection matrix with the sensitivities and elasticities for the fertility and survival rates of the fish for the 2-month closure without any gear restrictions.

Fig. A44. Sardinella aurita projection matrix with the sensitivities and elasticities for the fertility and survival rates of the fish for the 3-month closure without any gear restrictions. 128

Fig. A45. Sardinella aurita projection matrix with the sensitivities and elasticities for the fertility and survival rates of the fish for the 4-month closure without any gear restrictions.

Fig. A46. Sardinella aurita projection matrix with the sensitivities and elasticities for the fertility and survival rates of the fish for the 5-month closure without any gear restrictions. 130 Fig. A47. Sardinella aurita projection matrix with the sensitivities and elasticities for the fertility and survival rates of the fish for the 6-month closure without any gear restrictions. 131 Fig. A48. Sardinella aurita projection matrix with the sensitivities and elasticities for the fertility and survival rates of the fish for the 7-month closure without any gear restrictions. 132 
Fig. A49. Sardinella aurita projection matrix with the sensitivities and elasticities for the fertility and survival rates of the fish for the 8-month closure without any gear restrictions.

Fig. A50. Sardinella aurita projection matrix with the sensitivities and elasticities for the fertility and survival rates of the fish for the 9-month closure without any gear restrictions. 134

Fig. A51. Sardinella aurita projection matrix with the sensitivities and elasticities for the fertility and survival rates of the fish for the 10-month closure without any gear restrictions. 135

Fig. A52. Sardinella aurita projection matrix with the sensitivities and elasticities for the fertility and survival rates of the fish for the 11-month closure without any gear restrictions. 136

Fig. A53. Sardinella aurita projection matrix with the sensitivities and elasticities for the fertility and survival rates of the fish for the 1-month closure with gear restrictions.

Fig. A54. Sardinella aurita projection matrix with the sensitivities and elasticities for the fertility and survival rates of the fish for the 2-month closure with gear restrictions.

Fig. A55. Sardinella aurita projection matrix with the sensitivities and elasticities for the fertility and survival rates of the fish for the 3-month closure with gear restrictions. 
Fig. A56. Sardinella aurita projection matrix with the sensitivities and elasticities for the fertility and survival rates of the fish for the 4-month closure with gear restrictions.

Fig. A57. Sardinella aurita projection matrix with the sensitivities and elasticities for the fertility and survival rates of the fish for the 5-month closure with gear restrictions.

Fig. A58. Sardinella aurita projection matrix with the sensitivities and elasticities for the fertility and survival rates of the fish for the 6-month closure with gear restrictions.

Fig. A59. Sardinella aurita projection matrix with the sensitivities and elasticities for the fertility and survival rates of the fish for the 7-month closure with gear restrictions.

Fig. A60. Sardinella aurita projection matrix with the sensitivities and elasticities for the fertility and survival rates of the fish for the 8-month closure with gear restrictions.

Fig. A61. Sardinella aurita projection matrix with the sensitivities and elasticities for the fertility and survival rates of the fish for the 9-month closure with gear restrictions.

Fig. A62. Sardinella aurita projection matrix with the sensitivities and elasticities for the fertility and survival rates of the fish for the 10-month closure with gear restrictions. 
Fig. A63. Sardinella aurita projection matrix with the sensitivities and elasticities for the fertility and survival rates of the fish for the 11-month closure with gear restrictions. 


\section{MANUSCRIPT-I}

"Dynamics and Catch Composition of the Sardinella Fishery in Ghana"

by

Evans K. Arizi' ${ }^{1}$; Jeremy S. Collie ${ }^{2}$; Kathleen Castro ${ }^{3}$; Austin T. Humphries ${ }^{4}$

is intended to be submitted to Fisheries Research

${ }^{1} \mathrm{PhD}$ Candidate, Department of Fisheries, Animal and Veterinary Sciences, University of Rhode Island, Kingston, RI, 02881. Email: evansarizi@my.uri.edu

${ }^{2}$ Professor, Graduate School of Oceanography, University of Rhode Island, Narragansett, RI, 02882. Email: jcollie@uri.edu

${ }^{3}$ Research Associate, Department of Fisheries, Animal and Veterinary Sciences, University of Rhode Island, Kingston, RI, 02881. Email: kcastro@uri.edu

${ }^{4}$ Professor, Department of Fisheries, Animal and Veterinary Sciences, University of Rhode Island, Kingston, RI, 02881. Email: humphries@uri.edu 


\section{ABSTRACT}

The sardinella fishery in Ghana is vital to food and economic security for hundreds of thousands of people along the coast. Sardinella stocks, however, have been declining over the last three decades from overexploitation by artisanal and semi-industrial fleets. Nevertheless, little attention has been paid to the management of this fishery and the underlying fishery dynamics. The goal of this study was to describe the basic fisher and catch characteristics as a first step in understanding the fishery and setting the basis for management decisions. We sampled 8 sites along the coast of Ghana from 2017-2018 and collected data on over 14,000 individuals of sardinellas from 332 unique fishing trips. We found fishing gears that were variations on either beach seines, purse seines, or gill nets. Three types of purse seines were identified and distinguished based on mesh sizes: poli $\leq 3.0 \mathrm{~cm}$; watsa $>3.0 \mathrm{~cm}$; and poli-watsa had a combination of mesh sizes. Differentiation of gill nets was based on either monofilament (called "set net") or cotton (called "ali"). Poli-watsa constituted the most dominant gear (37\%) in the fishery. Two species of sardinella were captured, the round (Sardinella aurita) and the flat (Sardinella maderensis) sardinella. Ninety-six percent of the vessels were motorized. The ranges for the key attributes of the fishery were: vessel length $(5-23.8 \mathrm{~m})$; crew size ( 2 - 30 individuals per vessel); fishing duration (4 - 23 hours); net length (54.6 $959.7 \mathrm{~m})$; depth of fishing location $(4-100 \mathrm{~m})$; and mesh size $(0.7-7.5 \mathrm{~cm})$. About $62 \%$ of $S$. aurita and $75 \%$ of $S$. maderensis were juveniles. More $S$. aurita were landed in the poli-watsa fishery (26\%) whereas $S$. maderensis dominated the landings of the set net fishery $(22 \%)$. Considering the dominance of juveniles in the landings of the 
sardinella fishery in Ghana, management that reduces effort using specific gears or eliminates fishing during certain times of the year could be effective.

\section{INTRODUCTION}

Fisheries contribute to global food security and income generation (Kaiser, et al., 2005). Across the world, fishery systems have been evolving over time as a result of high demand for fish protein engendered by the increasing rate of the human population. This evolution is largely facilitated by technological advancements. Some of these technological developments include the advent of woven materials leading to the manufacture of finer and stronger fishing nets with relatively high catch efficiencies, introduction of large trawl nets, powered winches to retrieve nets into fishing vessels during hauling, freezer trawlers to store and preserve large catches and sonar devices to

locate fish in their natural environments (Jennings, Kaiser, \& Reynolds, 2001). Essentially, the motivation of fishers to maximize their catch has compelled them to modify their fishing devices. These modifications could be either detrimental or beneficial to the state of fish stocks (Dankel \& Edwards, 2016). In most cases, fishers take such initiatives with keen interest in maximizing their economic gains at the expense of fish stocks. For instance, the collapse of the Canadian cod fishery in 1992 was driven by high economic activities encouraged by technological modifications to fishing implements and methods in the face of overcapacity (Hutchings \& Myers, 1994). In principle, steps taken to adequately manage a fishery begin with gaining basic insight into the components of the fishery. Lawson (1984) asserts that fisheries management schemes could be successfully implemented if quality and appropriate data are available, citing an instance whereby deficient data used for preparation and 
implementation of US Fishery Management Plans in 1977 suffered as a consequence. Successful sustainable fisheries management is obviously facilitated by adequacy of knowledge about the fishery system to be managed. Hence, a well-formulated policy that considers the dynamical trend of modifications of fishery systems, especially the human subsystem is indispensable for effective management and conservation of fish stocks.

Ghana is one of the most popular fishing countries in West Africa with a coastline of $550 \mathrm{~km}$ (Nunoo, et al., 2016) and an annual fish landing of $329 \times 10^{6} \mathrm{~kg}$ (Asiedu, Afriyie, \& Amponsah, 2018). Ghana's fisheries range in size and are characterized as artisanal, semi-industrial and industrial with reference to technology level (Amador, et al., 2006; MOFAD, 2015). The marine fisheries of Ghana provide approximately $80 \%$ of the fish that is locally consumed and the highest production is contributed by sardinella fishery providing cheap protein to the populace (FAO, 2016). By implication, the livelihoods and subsistence of many fishermen in Ghana depend on the sardinella fishery (Bailey, et al., 2010). The sardinella stocks are mainly composed of round sardinella (Sardinella aurita) and the flat sardinella (Sardinella maderensis) (Koranteng, 1994; Kwei \& Ofori-Adu, 2005). Ecologically, S. aurita prefers deeper waters (offshore waters) whereas S. maderensis inhabits coastal waters (Whitehead, 1985).

The sardinella fishery which reportedly collapsed in 1972 but got revamped in the 90 s $(F A O, 1980)$ is presently in crisis with catches rapidly declining. The dwindling state of the sardinella catches is gradually affecting the livelihoods of the local fisher folks (Asiedu, et al., 2013). As a consequence, about $23 \%$ of the fisher folks in the 
marine fisheries have quit the fishing occupation (Dovlo, Amador, \& Nkrumah, 2016). The plummet in the sardinella landings has been presumably attributed to overcapacity in the fishery, open-access nature of the fishery and weak fisheries governance (CRC, 2014). Among these presumptive causes, overcapacity stands out to be the greatest threat to the fishery. Kwei (1961), Lawson and Kwei (1974), FAO (1980) and Koranteng (1994) acknowledge the significant changes in the artisanal fisheries of Ghana citing introduction of outboard engines to facilitate long fishing trips, adoption of synthetic netting material for fishing and introduction of purse seine net as examples. The popular gears that are deployed in the fishery include purse seine, gill net ("ali") and beach seine (Koranteng, 1989; Dovlo, Amador, \& Nkrumah, 2016). A handful of the local fishermen use ecosounders for their fishing activities; light fishing has also been reported in the fishery (Afoakwah, Osei, \& Effah, 2018). It is therefore likely that rapid evolution in the sardinella fishery (especially in the human subsystem) might have led to the decline in the sardinella landings.

Over the years, some attempts have been made to identify and describe the various fishing gears in the sardinella fishery as well as determine the catch compositions in the landings (e.g. FAO, 1980; Doyi, 1984; Koranteng, 1989; Koranteng, 1994). However, results have been equivocal and not investigated in over 20 years. Hence, this study sought to provide data on the dynamics and catch composition of the sardinella fishery in Ghana. The goal with these data is that they serve as a guide for fisheries managers and other stakeholders to plan towards the path of making the fishery sustainable in Ghana. 


\section{MATERIALS AND METHODS}

\section{Data collection}

The catch and size compositions of landings and fishery dynamics of the current sardinella fishery in Ghana were assessed using catch data from fish landings. This study was conducted in eight fishing communities selected from all the four coastal regions of Ghana (Fig. 1). These communities included Half-Assini and Axim in the Western Region, Elmina and Winneba in the Central Region, Bortianor and Tema in the Greater Accra Region, and Keta and Denu in the Volta Region. These communities were chosen to provide national coverage of the sardinella fishery. A trained field assistant was stationed at each sampling site to facilitate simultaneous data collection over the study period.

To provide present knowledge about the extractive component of the sardinella fishery, pieces of information on some key attributes of fishery such as crew size, type of fishing gear used, fishing duration per trip, net length and engine type were gathered from the fishermen through a semi-structured interview. The mesh size of each fishing net was measured to the nearest $0.01 \mathrm{~cm}$ whereas vessel length was measured to the nearest $0.1 \mathrm{~m}$. To ascertain the size composition of sardinella landings, fish samples were obtained from the fishermen, sorted into species (7, 240 S. maderensis; 6, 848 S. aurita) and each fish specimen was measured to the nearest $0.01 \mathrm{~cm}$ for its total length using a measuring board. We sampled from every fishing vessel that landed sardinella fish in each sampling day. Data were collected every other month for one year, from August 2017 to June 2018). 


\section{Data analysis}

These data were successfully analyzed using $\mathrm{R}$ programming software. We conducted a t-test to determine if there were differences in the frequency of the fishing gears. We also performed a one-way ANOVA to determine whether there were differences within the crew size, vessel length, net length, fishing duration and depth of fishing location among the various gears. Post-hoc comparison tests using Tukey's Honestly Significant Difference (HSD) were conducted to determine the specific differences between each pair of the fishery attributes (crew size, vessel length, net length, fishing duration and depth of fishing location) across the gears. Correlation analysis was also performed to understand the relationships among the attributes of the fishery and Bonferroni correction test was also performed to adjust the p-values. Histograms were also generated for the fish lengths to ascertain their length-frequency distributions in the landings of the fishery. We also used the Kolmogorov-Smirnov (KS) test to determine whether the length-frequency distributions differed between the fish species in the landings.

\section{RESULTS}

To identify the various kinds of fishing gears in the sardinella fishery, the mode of operation of each gear was ascertained through a semi-structured interview. From the results, 3 broad categories of fishing gears, namely purse seine, gill net and beach seine were among 332 gears that were encountered in the sardinella fishery. Six specific types were identified among these categories of gears, including poli, watsa, poli-watsa, ali, set net and beach seine. Poli, watsa, poli-watsa were purse seines whilst ali and set net were gill nets. These fishing gears comprised $12 \%$ poli, $9 \%$ watsa, $37 \%$ poli-watsa, $8 \%$ 
ali, $11 \%$ set net and $23 \%$ beach seine (Fig. 2) suggesting that the fishermen are deploying more poli-watsa nets to exploit the sardinella stocks in Ghana. However, the occurrence of the poli-watsa did not statistically differ significantly from the other gears, $t(5,95)=0.0007, p>0.05$

The length of fishing vessels in the sardinella fishery varied among the gears ranging from $5 \mathrm{~m}$ to $23.8 \mathrm{~m}$ suggesting a broad range of vessel sizes in the fishery (Fig. $3 \mathrm{~A})$. Generally, about $60 \%$ of the fishing vessels in the purse seine fishery of Ghana had their lengths greater than $15 \mathrm{~m}$ whereas $74 \%$ of canoes in the gill net fishery were less than $10 \mathrm{~m}$ in length. Approximately $89 \%$ of the canoes in the beach seine however, had their lengths within $10-15 \mathrm{~m}$. The differences in the vessel length among the gears were significant, $F(5,95)=1,706, p<0.05$; these significant differences were further confirmed by a post-hoc comparison test.

The crew size for the gears ranged from 2 individuals to 30 individuals per fishing vessel (Fig. 3B) indicating the variations in the number of fishers for a fishing vessel in the various gear fisheries within the nation's sardinella fishery. Two to four individuals per canoe observed in both ali and set net fisheries imply that few hands are required in operating gill nets. On the contrary, 5-30 fishers per fishing vessel in both purse seine and beach seine fisheries indicate that more hands are ideal for seining. We also found significant differences in the crew sizes among the gears, $F(5,95)=2,896, p$ $<0.05$. However, a post-hoc comparison test showed that crew size in the watsa and poli-watsa fisheries did not differ significantly $(p>0.05)$. The fishing duration also varied among the gear sub-fisheries ranging from 4 hours - 23 hours (Fig. 3C) suggesting a wide range of fishing hours in Ghana's sardinella fishery. Long fishing 
hours were generally observed in the purse seine fishery with an average of 16.4 hours. Fishing hours in the set net fishery was relatively short with an average of 6 hours. The fishing duration also differed significantly among the gears, $F(5,95)=1,192, p<0.05$. However, a post-hoc comparison test revealed that the fishing duration characterizing both poli and ali did not vary significantly $(p>0.05)$. Likewise, the durations for fishing activities in both watsa and poli-watsa did not vary significantly $(p>0.05)$.

The range of net lengths in the fishery was characterized by 54.6 - $959.7 \mathrm{~m}$ (Fig. 3D) with the longest deployed in the set net fishery. Although, the net length also differed significantly among the gears, $F(5,95)=157.3, p<0.05$, a post-hoc comparison test showed that net length did not differ significantly between these gears $(p>0.05)$ : poli-watsa and beach seine; set net and beach seine; watsa and beach seine; set net and poli-watsa; watsa and set net. The depth at which sardinella were fished ranged from 4 - $100 \mathrm{~m}$ with an average of $27.49 \mathrm{~m}$ (Fig. 3E) suggesting that sardinella are generally exploited in shallow coastal waters of Ghana. However, users of purse seines generally fished at depth ranging from 8-100 $\mathrm{m}$ with average of $34.09 \mathrm{~m}$ whereas both gill netters and beach seiners exploited the fish at depths of $4-54.6 \mathrm{~m}$ with a mean of $18.37 \mathrm{~m}$. This suggests that fishers in purse seine fishery mostly do their fishing in deep waters whilst fishers in both gill net and beach seine fisheries harvest the fish in shallow waters. The depth of fishing location also differed significantly among the gears, $F(5,95)$ $=820.2, p<0.05$; these significant differences were further confirmed by a post-hoc comparison test.

The range of mesh sizes with the mean mesh size (in italics) of each fishing gear recorded in this study is given in parenthesis as follows: Poli $(0.7-3.0 \mathrm{~cm} ; 1.5 \mathrm{~cm})$, 
watsa $(3.2-7.0 \mathrm{~cm} ; 4.2 \mathrm{~cm})$ and poli-watsa $(0.7-6.4 \mathrm{~cm} ; 3.0 \mathrm{~cm})$, ali $(2.0-5.2 \mathrm{~cm}$; $4.1 \mathrm{~cm})$, set net $(1.0-4.6 \mathrm{~cm} ; 2.7 \mathrm{~cm})$ and beach seine $(0.8-7.5 \mathrm{~cm} ; 2.9 \mathrm{~cm})$ as shown in (Fig. 3F). The mesh sizes of the nets also differed significantly among the nets, $F$ $(5,95)=41.91, p<0.05)$. However, a post-hoc comparison test showed that mesh size did not differ significantly between these gears $(p>0.05)$ : watsa and ali; poli-watsa and beach seine; set net and beach seine.

To properly understand the variations in hours and distances covered by the various groups of the fishers during their fishing activities, information on motorization of fishing vessels was also gathered. Generally, the result shows that about $96 \%$ of the fishing vessels in the sardinella fishery of Ghana were motorized; the remaining 4\% however utilized paddles to facilitate their fishing activities. All the vessels in the purse seine fishery were motorized. Similarly, all the fishing vessels in the ali fishery had outboard-powered motors. Most of these motors were 40-HP outboard motors. In the beach seine fishery, $95 \%$ of the canoes relied on outboard motors to set their nets in the coastal waters of Ghana prior to hauling whereas the remaining $5 \%$ used paddles to facilitate their fishing activities. Likewise, $87 \%$ of vessels in the set net fishery depended on outboard motors to do their fishing activities as against $13 \%$ using paddles.

The next step of the analysis focused on ascertaining the explicit association between a pair of the key attributes of the fishery. The result shows that, with the exception of fish length and vessel length whose linear relationship was insignificant $\left(R^{2}=0.002 ; p>0.05\right)$, significant linear relationships existed between vessel length, crew size, fishing duration, depth of fishing location, net length and fish length with an indication that there is some degree of interdependence between many pairs of the 
attributes in the fishery (Fig. 4). Vessel length in Ghana's sardinella fishery positively correlated moderately with the crew size $\left(R^{2}=0.53\right)$ and this relationship was statistically significant $\left(R^{2}<0.05\right)$ indicating that crew size depends on the size of the fishing vessel to a large extent. Similarly, crew size in the fishery positively correlated moderately with depth of fishing location $\left(R^{2}=0.46\right)$; this relationship was also statistically significant $(p<0.05)$ suggesting that the depth at which fishing occurs partly depends on the crew size. There was a significant moderate correlation between fishing duration and depth of fishing location in the fishery $\left(R^{2}=0.41 ; p<0.05\right)$ indicating that, to some extent, time taken for fishing is dependent on the depth at which fishing is done.

The crew size in the fishery positively correlated with the time taken for fishing $\left(R^{2}=0.39 ; p<0.05\right)$ showing that the time taken for fishing sometimes depends on the number of fishers in a vessel. Similarly, the fishing duration also correlated with length of the fishing vessel in the fishery $\left(R^{2}=0.32 ; p<0.05\right)$ implying that fishing duration depends on the size of the fishing vessel to some extent in the sardinella fishery. Sardinella fish size in the landings weakly positively correlated significantly with fishing duration $\left(R^{2}=0.28 ; p<0.05\right)$ suggesting that fish length of sardinella does not always depend on the time utilized for fishing in Ghana. Similarly, depth of fishing location correlated weakly with length of fishing vessels and this correlation was positive and significant $\left(R^{2}=0.28 ; p<0.05\right)$ suggesting that $28 \%$ of variability in depth of fishing location could be explained by fishing vessel size. The rest of the relationships between other pairs were either weakly or negligibly correlated.

Size composition of the fish in the landings was determined from lengthfrequency distribution using 14,088 fish individuals comprising 7,240 S. maderensis 
and 6,848 S. aurita for their lengths. Generally, the length distribution of $S$. maderensis in landings was unimodal with a mode of $11 \mathrm{~cm}$ (Fig. 5a) whereas that of S. aurita was bimodal with a global mode of $10 \mathrm{~cm}$ (Fig. 5b). Approximately $75 \%$ of S. maderensis and $62 \%$ of $S$. aurita in the landings were below their respective lengths at sexual maturity ( $\left.\mathrm{L}_{\mathrm{mat}}\right)$. The length-frequency distributions of the two fish species in the landings were significantly different $(D=0.115 ; p<0.05)$.

Among the 332 trips that were recorded in this study, the set net fishery contributed $22 \%$ of the $S$. maderensis to the landings which represented the greatest proportion (Fig. 6). The poli-watsa fishery contributed $26 \%$ of the $S$. aurita representing the highest contribution. Equal proportions of the two species were landed in the beach seine fishery.

\section{DISCUSSION}

Findings of this study indicate that fishers in the artisanal and semi-industrial fisheries of Ghana are utilizing 3 broad categories of fishing gears, namely purse seine, gill net and beach seine to exploit sardinella in the nation's coastal waters. The categorization of these gears is based on their mode of operation. Similar observations were reported by previous studies including FAO (1980), Doyi (1984) and Koranteng (1989). These categories have also been consistently captured in the recent canoe frame

surveys of Ghana (Akyeampong, Amador, \& Nkrumah, 2013; Dovlo, Amador and Nkrumah, 2016). The consistency in the usage of these gears in the sardinella fishery suggests that fishers do not seem to have any other options. The differences in the mode of operation of the gears could be attributed to the proximity of their respective fishing areas to the coast and distribution of sardinellas in the waters of Ghana (Koranteng, 
1994). Efforts in gathering data on sardinellas from the industrial fishery sector of the marine fisheries of Ghana proved futile due to difficulties in accessing the concerned fishers at the Tema Fishing Harbor. As a result of this, information on the sardinella fishery with respect to the industrial fishery was excluded from this paper. Nonetheless, a one-month preliminary survey conducted in 2017 using sardinella catches from the industrial fishery through "Saiko fishing" (transshipment) revealed that adult individuals of $S$. aurita were being exploited in the sector. These individuals constituted a small fraction as bycatch. It is imperative to note that other small pelagic fish (e.g. horse mackerels) are exploited in addition to sardinellas as bycatch in the industrial fishery. Results of this study also revealed that poli, watsa, poli-watsa, ali, set net and beach seine were the 6 specific fishing gears in the sardinella fishery of Ghana. Fishing net with a purse line at the bottom making the net take a form of purse to retain fish whenever it is closed could be regarded as purse seine; a net with panels of netting that is set vertically in the water column by a series of floats attached to its upper line and weights attached to its lower line to catch fish mostly by their gills could be described as gill net (King, 1995; von Brandt, 2005). From these definitions, we also regarded poli, watsa, poli-watsa identified as purse seines; ali and set nets as gill nets.

Certain characteristics of these gears in the present study, however differed from those reported by earlier workers. In this study, the differences in purse seines were based on mesh sizes whereas differences in gill nets were mainly premised on type of material. From the results, purse seine nets in the sardinella fishery could be differentiated based on mesh size as: poli $\leq 3.0 \mathrm{~cm}$; watsa $>3.0 \mathrm{~cm}$; and poli-watsa had a combination of mesh sizes peculiar to both poli and watsa. FAO (1980) reported purse 
seines as poli $(1.0-1.5 \mathrm{~cm})$ and 'atsiki no ye' (unspecified mesh size). Relatedly, Doyi (1984) identified poli with a mean mesh size of $1.3 \mathrm{~cm}$, watsa $(5.0-6.0 \mathrm{~cm})$ and 'achiki na oye' $(2.5-3.0 \mathrm{~cm})$. Comparing earlier mesh sizes with the present ones, it could be deduced that remarkable changes have been made to these fishing gears. These changes could be viewed as a strategy to enhance the catch rates of the nets.

Poli-watsa was missing in the reports of FAO (1980) and Doyi (1984) but was later identified and described by Doyi and Neequaye (1990). Historically, ali existed as a traditional gear prior to the introduction of purse seines in the waters of Ghana in 1959 (FAO, 1980). The chronological introduction of purse seines into the fishery provides evidence of the evolutionary processes occurring in the fishery over time. Considering how mesh sizes of poli and watsa overlap to give rise to poli-watsa, it is crucial to rely on the range of mesh sizes other than the mean to identify these gears in the fishery. 'Atsiki no ye' and 'achiki na oye' which are presumed to be the same type of purse seine but with different spellings might be equated with the modern-day poli-watsa. The study also captured poli-watsa as the preponderant fishing gear in the sardinella fishery of Ghana. The dominance of poli-watsa in the sardinella fishery could be due to the eagerness of many fishers to deploy a fishing gear with a variety of mesh sizes to exploit fish at the various stages in order to boost their landings as illustrated in Fig. 6.

One type of beach seine with a bunt which was encountered throughout this study is an indication that only one kind of beach seine is utilized in the sardinella fishery of Ghana. These findings are in consonance with those of the previous workers (e.g. FAO, 1980; Doyi, 1984; Koranteng, 1994) but disagree with the work of FAO (2011) in which two types of beach seines in the fishery based on net length, crew size 
and canoe size were reported: (a) smaller net of $200-300 \mathrm{~m}$ in length and $2.5-3 \mathrm{~m}$ deep usually set from a canoe of about $9 \mathrm{~m}$ in length by $12-20$ persons ; (b) larger net measuring up to $600 \mathrm{~m}$ and $4 \mathrm{~m}$ deep operated from $11-\mathrm{m}$ canoe by crew of $30-50$. As demonstrated in this study, a wide range of net length and crew size which were weakly correlated indicates that classification of beach seines based on these metrics could be misleading. From the present results, purse and beach seines were generally characterized by large crew size. In Ghana, seining is more laborious than gill netting. This might have accounted for the large crew size recorded generally in the seining sector of the fishery as compared to small crew size observed in the gill net fishery.

Ali as the pioneering and dominant gear in the past represented the lowest frequent gear in this study. Ali is a multifilament net constructed from cotton which makes it more expensive than set net, a monofilament net made of nylon (CRC, 2013). The heaviness of ali when it is wet makes its utilization difficult for users of small canoes as against set net which is not only light in weight but efficient in catching fish. From these accounts, it is quite probable that many fishers in the gill net fishery sector are no longer interested in using ali; this possibly explains the rarity of ali in the sardinella fishery these days. From this study, the longest net was encountered in the set net fishery, despite the use of small canoes in this sub-fishery. As indicated earlier, the inexpensive and light nature of the set net possibly encouraged the fishermen to construct longer nets for their fishing activities.

The study also revealed that a wide range of fishing vessels with different sizes are utilized in the sardinella fishery. This confirms the findings of Doyi (1984), Akyeampong, Amador and Nkrumah (2013) and Dovlo, Amador and Nkrumah (2016). 
Nevertheless, some of the fishing vessels which had lengths of about 20 - $24 \mathrm{~m}$ appear to be higher than those previously reported in the artisanal fishery. This increase could be a way to employ more hands to boost fish production. Crew size and depth of fishing location usually depend on the size of the fishing vessel as evidenced in the correlation analysis. It is also shown in this study that large vessels normally carried more fishers to deeper waters to harvest sardinella in Ghana. Particularly, majority of fishers in the purse seine fishery who were noted for using large fishing vessels $(<15 \mathrm{~m})$ fished in deeper waters and thereby spent long hours to harvest and land their catch. In contrast, gill net fishery characterized by small crew size mostly used small canoes to harvest their catch in relatively shallow waters, spending few hours do carry out their fishing activities. In the beach seine fishery, the canoe crew made up of paddlers (vessels without outboard machines), net-releasing crew, swimmers and the "horseman" (captain) are in charge of setting the net in the coastal waters. Prior to setting a beach seine, one wing of the net is left on the shore whilst, in the setting process, the other wing is brought to the shore by the swimmers to initiate the hauling process (Kraan, 2006). From this account, it is obvious that canoes are not used throughout the fishing operation in the beach seine fishery but needed to facilitate the net setting procedure. The canoe crew which constitutes an important component of the beach seine fishery accounts for the use of many vessels with intermediate lengths between those of purse seine and gill net fisheries.

As demonstrated in this study, a bigger crew requires a big fishing vessel. A big vessel can go further offshore for longer periods and fish at greater depths. However, bigger boats don't necessarily use bigger nets or catch bigger fish. There is a slight trend 
for large fish to be caught at greater depths on longer trips. All the vessels in the purse seine fishery were motorized and this could explain why majority of this group of fishers did their fishing in deeper waters. Long hours taken by the purse seiners to carry out their fishing activities could be explained by the distance covered to reach the fishing grounds which were usually found in deeper waters. The poor correlation that existed between net length and fish size provides evidence that the size of a net had a negligible impact on the fish sizes in the sardinella landings. Sardinella fish of various sizes landed in Ghana does not depend on the length of the fishing vessel as demonstrated in the correlation analysis. The absence of direct contact of fishing vessels with fish could possibly explain this null relationship between fish length and vessel length. By implication, relationships which either poorly or negligibly existed between some pairs of the key attributes of the sardinella fishery could be seen as unreliable for practical predictions. The small $\mathrm{R}^{2}$ values with small $\mathrm{p}$-values could be attributed to the large sample size.

This study also shows that a greater proportion of sardinella landed in Ghana are juveniles. The predominance of juveniles as evidenced in the modal length of each species implies that the fishermen are possibly using fishing gears with under-sized mesh sizes to exploit the stocks presently. The study also revealed that whereas majority of the S. aurita were landed in the purse seine fishery (sum of catch landed by users of poli, watsa and poli-watsa), more $S$. maderensis were landed in the gill net fishery (sum of catch landed by users of set net and ali). S. aurita mostly winters at depths of $50-80$ $\mathrm{m}$ off central Ghana, although this fish has been described as a highly migratory species (Zei, 1962; Koranteng, 1989; Brainerd, 1991). On the contrary, S. maderensis is less 
migratory and inhabits coastal waters of depths up to $50 \mathrm{~m}$ (Whitehead, 1985). Hence, the high catch composition of $S$. aurita in the purse seine nets (usually deployed in deep waters) and of $S$. maderensis in the gill net (used in shallow waters) could be explained by the distribution of the two species in the coastal waters. Greater proportion of $S$. aurita in the poli-watsa landings could due to high occurrence of the poli-watsa in the fishery and the wide ranges of mesh sizes the net possesses. The catching properties of both poli and watsa possessed by poli-watsa could possibly explain the bimodal size distribution of $S$. aurita in the landings. The higher proportion of $S$. maderensis in the set net landings could be ascribed to the high frequency of set net in the gill net fishery as well as high efficiency of the net. Equal proportions of the two species that were landed in the beach seine fishery could be due to the hauling process which mostly begins in deep waters and ends on land.

\section{CONCLUSIONS}

Six kinds of fishing gears, namely poli, watsa, poli-watsa, ali, set net and beach seine were recorded among the artisanal and semi-industrial fleets of the sardinella fishery of Ghana. These gears fall broadly into purse seine (poli, watsa and poli-watsa), gill net (ali and set) and beach seine categories. Purse seines were differentiated based on mesh sizes as follows: poli $\leq 3.0 \mathrm{~cm}$; watsa $>3.0 \mathrm{~cm}$; poli-watsa had a combination of poli and watsa mesh sizes. The difference between the two gill nets were based on the nature of the net material: ali (multifilament cotton material); set net (monofilament nylon material). Poli-watsa constituted the preponderant fishing gear in the sardinella fishery. The crew size usually depended on the length of the fishing vessel. 
About $96 \%$ of the fishing vessels were motorized in the sardinella fishery. Sardinella landings were predominately juveniles. Purse seines are catching more $S$. aurita whereas gill nets are harvesting more $S$. maderensis. The findings of this study which vary from the existent ones call for periodic assessment of the sardinella fishery to guide policy-makers and managers in their decision-making. For management and conservation purposes, it is recommended that further research should focus on how the gears interact with the fish in order to identify the specific gears which are exploiting the fish below the length at sexual maturity $\left(L_{m}\right)$ in the fishery.

\section{ACKNOWLEDGEMENT}

The financial support provided by USAID through Ghana Sustainable Fisheries Management Project (SFMP) is fully acknowledged. We are also grateful to the field assistants for their immense contributions towards the data collection. 


\section{REFERENCES}

Afoakwah, R., Osei, M., \& Effah, E. (2018). A Guide on Illegal Fishing Activities in Ghana. University of Rhode Island, Coastal Resources Center, Graduate School of Oceanography. Narragansett: University of Rhode Island.

Akyeampong, S., Amador, K., \& Nkrumah, B. (2013). Report on the 2013 Ghana marine canoe frame survey. Ministry of Fisheries and Aquaculture Development, Fisheries Commission, Fisheries Scientific Survey Division. Accra: Republic of Ghana.

Amador, K., Bannerman, P., Quartey, R., \& Ashong, R. (2006). Ghana canoe frame survey. Marine Fisheries Research Division. Accra: Ministry of Food and Agriculture.

Asiedu, B., Afriyie, G., \& Amponsah, S. (2018, August 29th). Overview of marine stock enhancement, restocking and sea ranching in Ghana. Retrieved July 2019, from Public Management and Administration: http://dx.doi.org/10.5772/intechopen.79454

Asiedu, B., Nunoo, K. E., Ofori-Danson, K. P., Sarpong, B. D., \& Sumaila, R. U. (2013). Poverty measurements in small-scale fisheries of Ghana: a step towards poverty eradication. Current Research Journal of Social Sciences, 3(5), 75 - 90.

Bailey, M., Quaatey, S., Armah, A. K., Jacquet, J., Khan, A., Alder, J., \& Sumailia, R. (2010). Meeting socioeconomic objectives in Ghana's sardinella fishery. In D. M. Nanang, \& T. K. Nunifu, Natural Resources in Ghana (p. 17). Nova Science Publishers, Inc. 
Brainerd, T. R. (1991). The sardinella fishery off the coast of West Africa: the case of a common property resource. Paper presented at the Second Annual Conference of the International Association for the Study of Common Property (IASCP), University of Manitoba, Winnipeg, Canada.

CRC. (2013). Global lessons and information to assist with monofilament gill net management in Ghana. USAID Integrated Coastal and Fisheries Governance Program for the Western Region of Ghana. University of Rhode Island, Coastal Resources Center, Graduate School of Oceanography, Narragansett.

CRC. (2014). Ghana's small pelagic fishery in crisis: national and regional food security at risk. Retrieved June 2019, from https://www.crc.uri.edu/download/GH2014_COM003_CRC_FIN508.pdf

Dankel, J. D., \& Edwards, T. T. (2016). Fishery systems and the role of management science. In T. T. Edwards, \& J. D. Dankel, Management science in fisheries: an introduction to simulation-based methods (pp. 1-15). New York: Routledge.

Dovlo, E., Amador, K., \& \& Nkrumah, B. (2016). Report on the 2016 Ghana marine canoe frame survey. Accra: Republic of Ghana.

Doyi, B. A. (1984). Catalogue of small-scale fishing gear of Ghana. Rome: Food and Agriculture Organization.

Doyi, B. A., \& Neequaye, G. (1990). Report on pilot artisanal fishing gear survey in Ghana. Tema: Fishery Research and Utilization Branch.

FAO. (1980). Report of the ad hoc working group on Sardinella off the Coast of Ivory Coast - Ghana - Togo. Rome: Publications Division, Food and Agriculture Organization of the United Nations. 
FAO. (2011). Fishing with beach seines. Rome: FAO.

FAO. (2016, February). Fishery and Aquaculture Country Profiles. (FAO Fisheries and Aquaculture Department) Retrieved June 2019, from http://www.fao.org/fishery/facp/GHA/en

Hutchings, J. A., \& Myers, R. A. (1994). What can be learned from the collapse of a renewable resource?Atlantic cod, Gadus morhua, of Newfoundland and Labrador. Canadian Journal of Fisheries and Aquatic Sciences, 2126 - 2146.

Jennings, S., Kaiser, J. M., \& Reynolds, D. J. (2001). Marine Fisheries Ecology. Oxford: Blackwell Science Ltd.

Kaiser, J. M., Attrill, J. M., Jennings, S., Thomas, N. D., Barnes, K. A., Brierley, S. A., . . Raffaelli, G. D. (2005). Marine ecology: processes, systems, and impacts. New York: Oxford University Press.

King, M. (1995). Fisheries biology, assessment and management. London: Blackwell Science Ltd.

Koranteng, K. A. (1989). The sardinella fishery in Ghana, the past, recent development and the years ahead. Tema: Fisheries Department Research and Utilization Branch.

Koranteng, K. (1994). The Ghanaian fishery for sardinellas. Workshop $<<$ Dynamics and Uses of Sardinella resources from upwelling off Ghana and Côte d'Ivoire >> (DUSRU). Accra.

Kraan, M. (2006). 'One Man No Chop'. Beach seine fishing in Ghana (West Africa). Mast, 1(5), 117-128. 
Kwei, E. A. (1961). Recent developments in the canoe fisheries in Ghana. Ghana Journal of Science, 1(1,2), 29-35.

Kwei, E., \& Ofori-Adu, D. (2005). Fishes in the coastal waters of Ghana. Tema, Ghana: Ronna Publishers.

Lawson, R. M. (1984). Economics of fisheries development. London, UK: Bloomsbury Publishing Plc.

Lawson, R. M., \& Kwei, E. A. (1974). African entrepreneurship and economic growth: A case study of the fishing industry of Ghana. Accra: Ghana Universities Press.

MOFAD. (2015). Fisheries Management Plan. Accra: Ministry of Fisheries and Aquaculture Development, Goverment of Ghana.

Nunoo, F. K., Asiedu, B., Amador, K., Belhabib, D., \& Pauly, D. (2016). Ghana. In D. Pauly, \& D. Zeller, Global atlas of marine fisheries: a critical appraisal of catches and ecosystem impacts (p. 277). Washington, DC: Island Press.

von Brandt, A. (2005). Fishing catching methods of the world. New Delhi: Wiley Blackwell Publishing Ltd.

Whitehead, P. J. (1985). FAO species catalogue. Vo1.7. Clupeoid fishes of the world. An annotated and illustrated catalogue of the herrings, sardines, pilchards, sprats, anchovies and wolf- herrings. Part 1 - Chirocentridae, Clupeidae and Pristigasteridae. Rome: Food and Agriculture Organization of the United Nations.

Zei, M. (1962). Marine fisheries research Ghana - its scope and development in 1962. Fisheries Research Report, 1(1), pp. 1-4. 


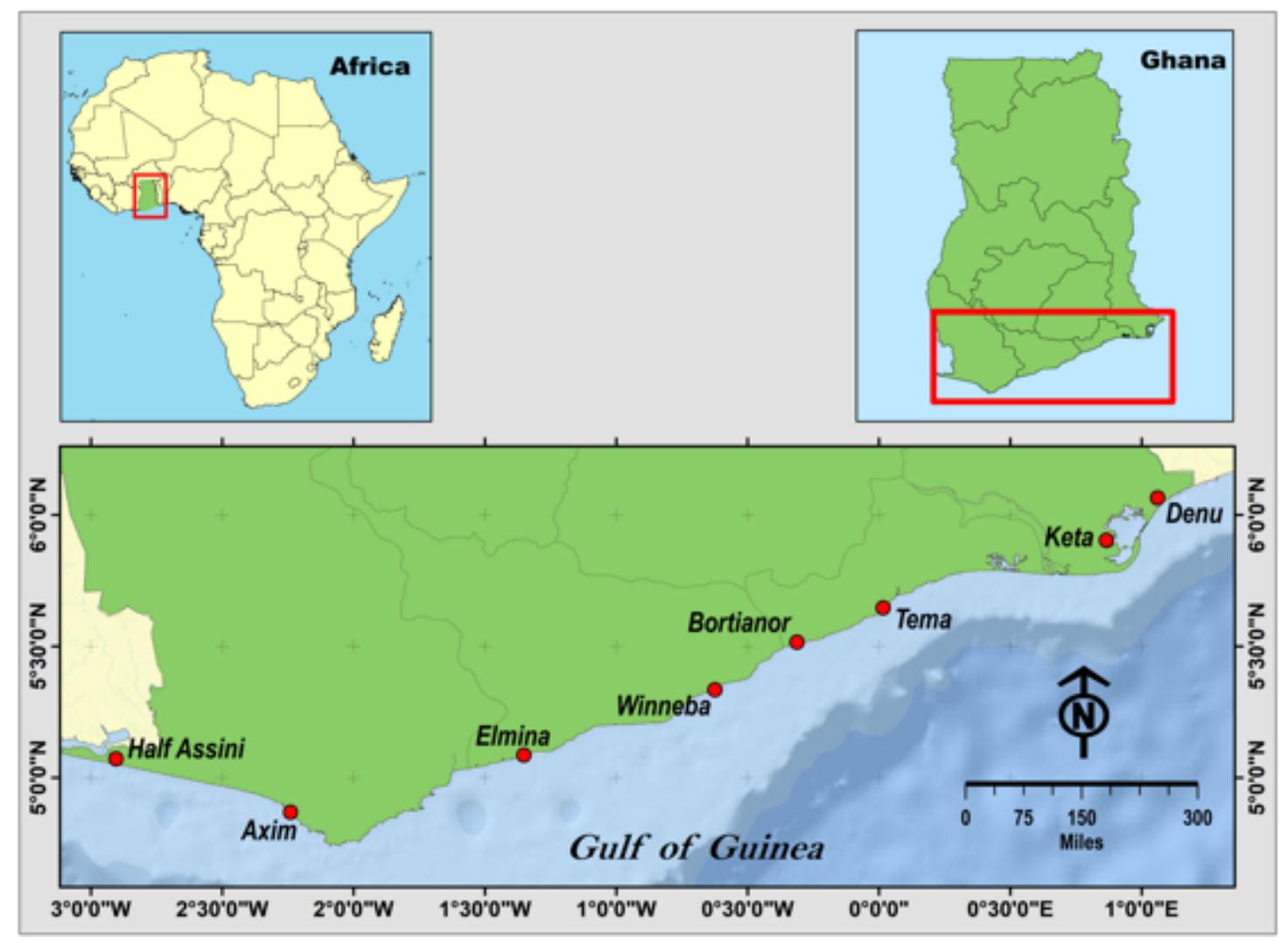

Fig. 1. Sampling sites along the coast of Ghana. 


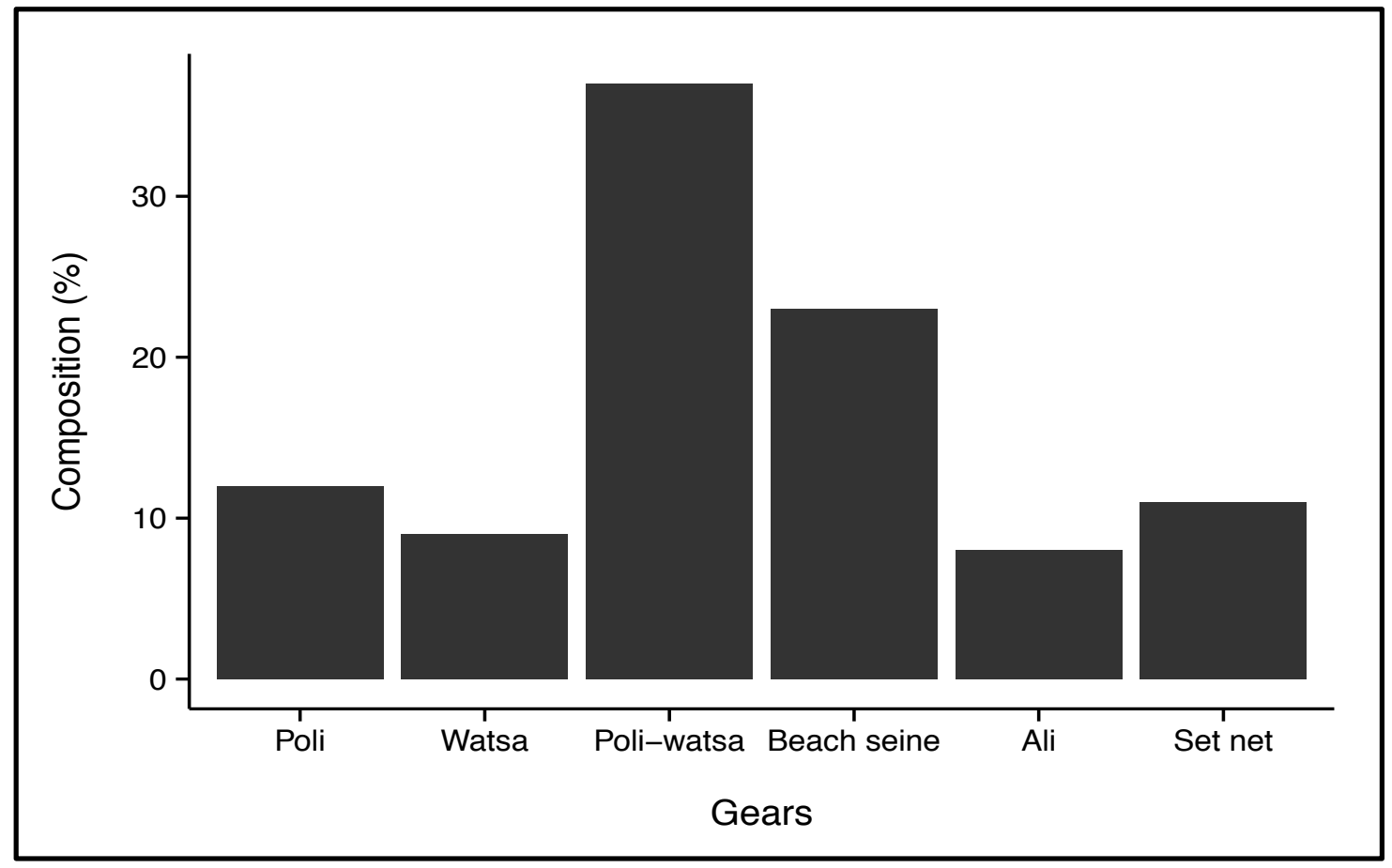

Fig. 2. Percent composition of fishing gears in the sardinella fishery of Ghana 


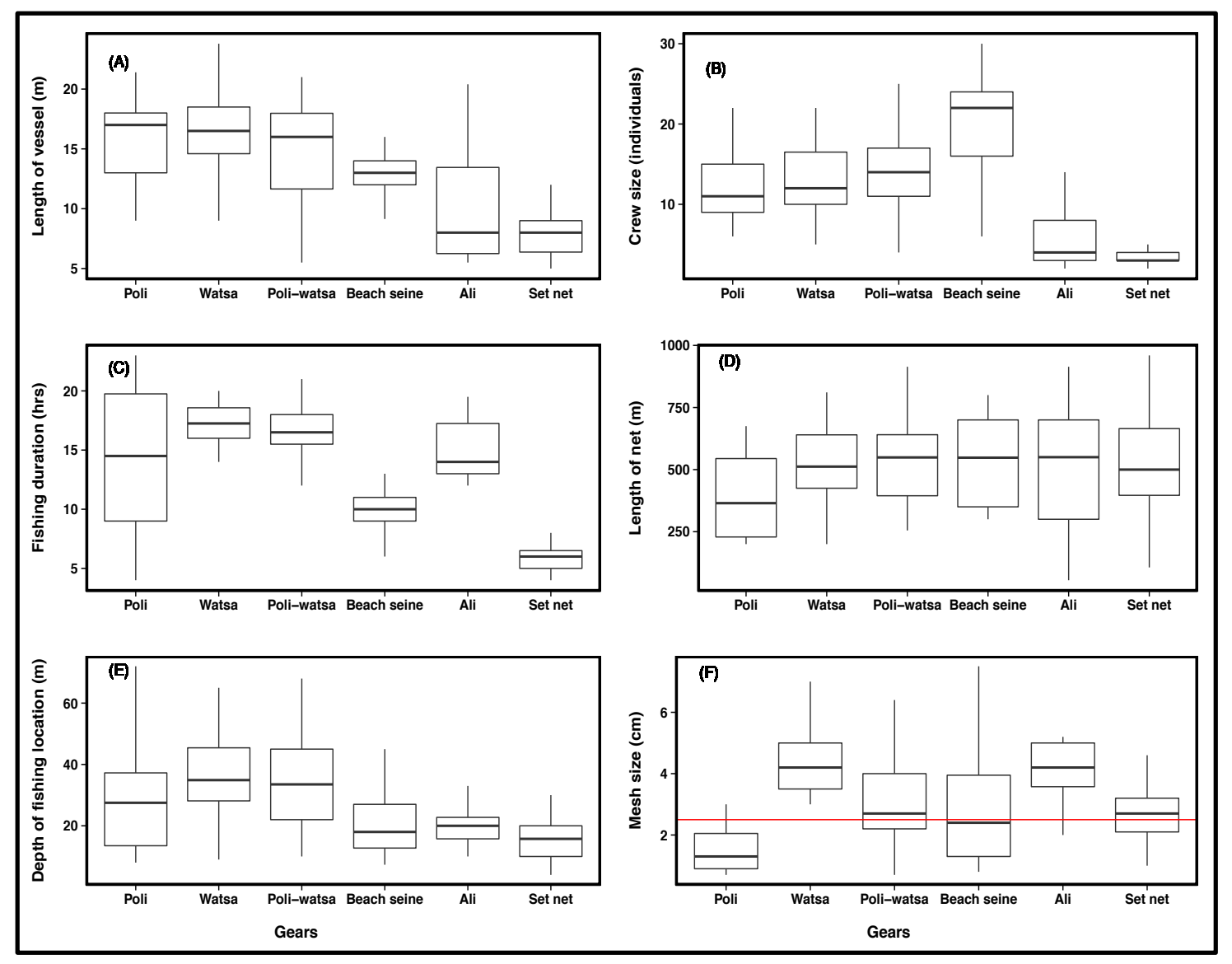

Fig. 3. Length of fishing vessels (A), crew size (B), fishing duration (C) and length of fishing nets (D), depth of fishing location (E), mesh size (F) of the various gears in the sardinella fishery of Ghana. Outliers data points are not shown. Red line indicates the legal mesh size of $2.5 \mathrm{~cm}$ enshrined in the Fisheries Act of Ghana 


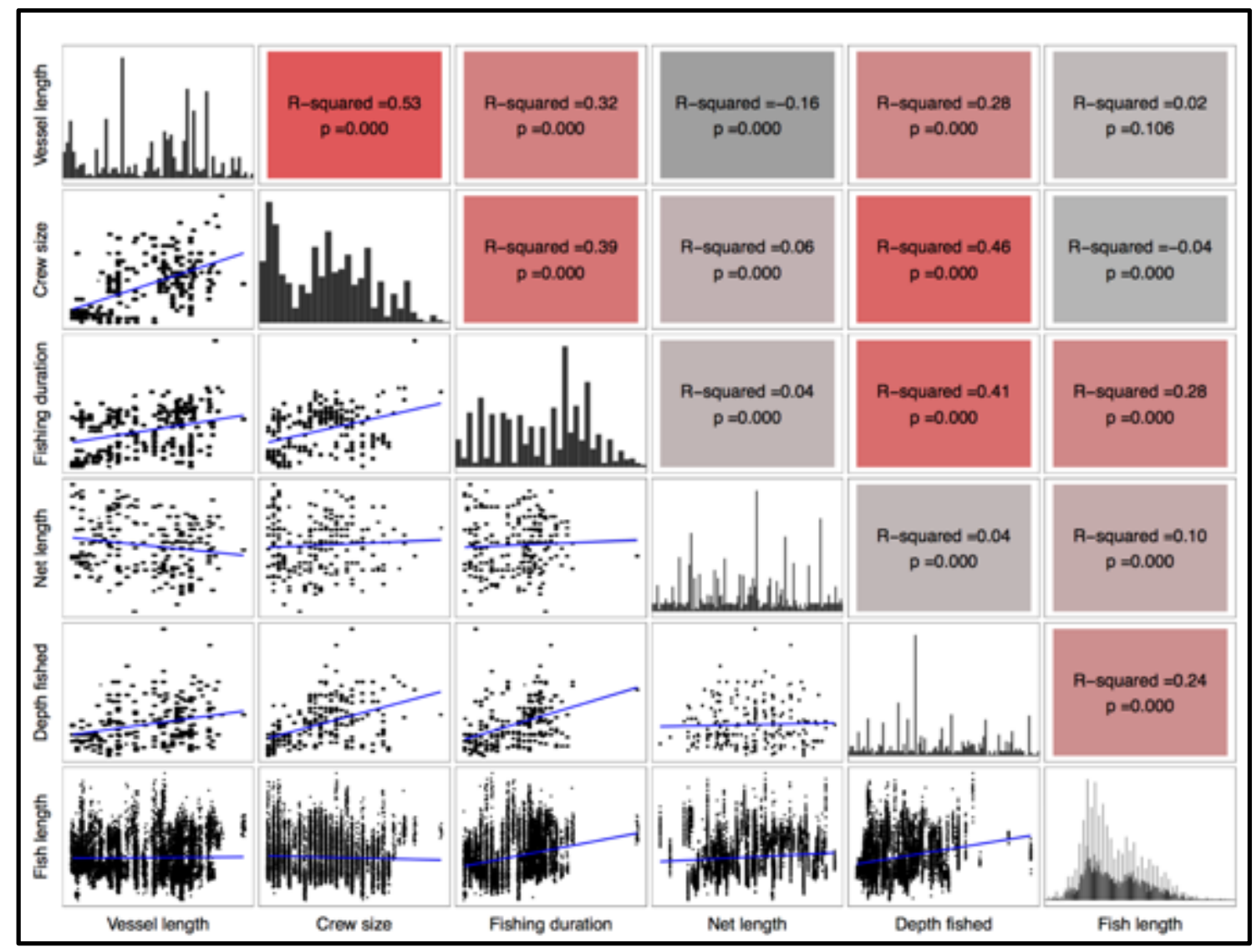

Fig. 4. Correlation between some key attributes in the sardinella fishery of Ghana 


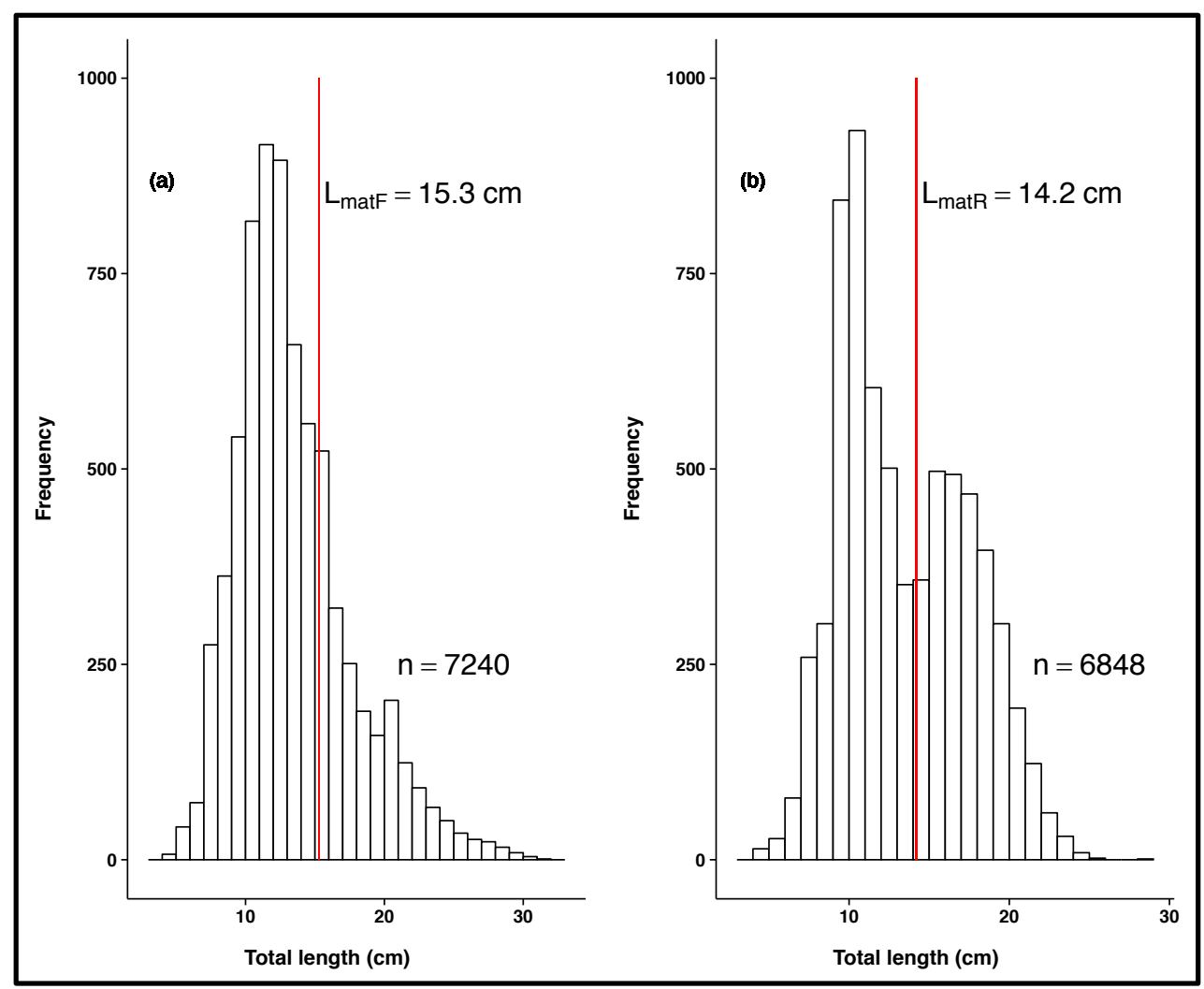

Fig. 5. Length-frequency distributions of (a) flat sardinella and (b) round sardinella in the marine fisheries of Ghana. Red lines indicate the length at first sexual maturity for flat sardinella $\left(\mathrm{L}_{\mathrm{matF}}\right)$ and for round sardinella $\left(\mathrm{L}_{\mathrm{matR}}\right)$ 


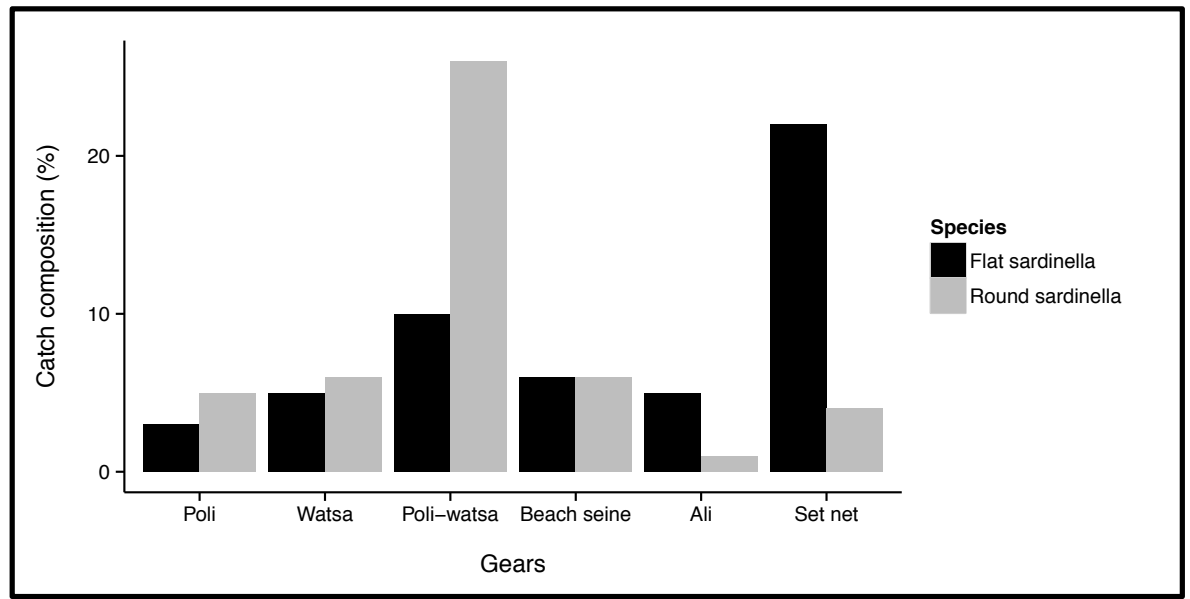

Fig. 6. Catch composition of flat and round sardinellas for each fishing gear in the marine fisheries of Ghana 


\title{
MANUSCRIPT-II \\ "Species-Gear Interactions in the Sardinella Fishery of Ghana"
}

\author{
by \\ Evans K. Arizi ${ }^{1}$; Jeremy S. Collie ${ }^{2}$; Kathleen Castro ${ }^{3}$; Austin T. Humphries ${ }^{4}$ \\ is intended to be submitted to Marine Ecology Progress Series
}

${ }^{1} \mathrm{PhD}$ Candidate, Department of Fisheries, Animal and Veterinary Sciences, University of Rhode Island, Kingston, RI, 02881. Email: evansarizi@my.uri.edu

${ }^{2}$ Professor, Graduate School of Oceanography, University of Rhode Island, Narragansett, RI, 02882. Email: jcollie@uri.edu

${ }^{3}$ Research Associate, Department of Fisheries, Animal and Veterinary Sciences, University of Rhode Island, Kingston, RI, 02881.Email: kcastro@uri.edu

${ }^{4}$ Professor, Department of Fisheries, Animal and Veterinary Sciences, University of Rhode Island, Kingston, RI, 02881. Email: humphries@uri.edu 


\section{ABSTRACT}

Sardinella stocks made up of flat sardinella (Sardinella maderensis) and round sardinella (Sardinella aurita) form the mainstay of the artisanal fisheries of Ghana. The landings of these stocks, however, have been dominated by small, immature fish in recent years. Yet, no comprehensive assessment has been conducted to identify the fishing gears that unsustainably harvest juvenile fish and what factors drive their distribution. In this study, we examined the distribution of sardinella species in the Ghanaian fishery and used length at first sexual maturity $\left(L_{m}\right)$ of the fish as a reference point to determine the composition of the catches for each gear type and season. $S$. maderensis preferred coastal waters up to $65 \mathrm{~m}$ in depth, whereas $S$. aurita inhabited waters of depth up to $500 \mathrm{~m} . S$. maderensis matured at $15.3 \mathrm{~cm}( \pm 0.013, \mathrm{~N}=1,777)$, which was greater than $S$. aurita at $14.2 \mathrm{~cm}( \pm 0.004, \mathrm{~N}=2,684)$. Recruitment of young fish into the sardinella stocks occurred throughout the year. Fishers used different gears to catch a wide variety of sizes of the two sardinella species at different depths and in different seasons. The average probability of capturing immature fish per each gear type was: beach seine $(68 \%)>$ poli $(46 \%)>\operatorname{set}$ net $(43 \%)>$ ali $(22 \%)>$ watsa $(4 \%)$. In other words, ali and watsa fishers were catching the majority of their fish above $L_{m}$. Fishers using poli, poli-watsa, beach seine and set net, however, were generally harvesting individuals below $L_{m}$ suggesting that more juveniles are harvested by poli, poli-watsa, beach seine users in Ghana. These findings provide a baseline to encourage an increase in mesh sizes of poli, poli-watsa, beach seine and set net to a minimum size of $2.5 \mathrm{~cm}$ as a management tool to complement the ongoing seasonal closure in Ghana. 


\section{INTRODUCTION}

Fish-gear interactions are of great concern to fisheries scientists and managers because such interactions dictate how fish species and size are selected during exploitation (Adimey, et al., 2014; Cardoso, et al., 2015; Cashion, et al., 2018). The interaction of fish with fishing gears in aquatic systems could either result in the death, injury, suffocation, poor growth, reduced fitness or reduced fecundity of the fish (Knowlton \& Kraus, 2001; Benjamins, et al., 2012). Furthermore, fishing as a function of fish-gear interactions could adversely affect the life history characteristics of fish stocks (Crespo \& Dunn, 2017). For instance, size-selective fishing can alter the size or age structure (Toresen, 1990), sex ratios (Thompson \& Munro, 1983; Buxton, 1993; Sadovy, 1996) and genetic structure (Smith, Francis, \& McVeagh, 1991) with resulting limitation of reproductive life span of fish stocks. Poor diversity, extinction and extirpation of fish stocks are some of the possible aftermaths of fish-gear interactions (Dulvy, Metcalfe, Glanville, Pawson, \& Reynolds, 2000). The impacts of fishing gears on fish stocks could be understood satisfactorily when adequate knowledge of fish-gear interactions is readily available. Scientific knowledge about how fishing gears interact with fish stocks is critical for providing robust policies to manage exploited fish resources.

Many fisheries in the developing nations have been threatened by inappropriate fishing methods and gears (Purcell \& Pomeroy, 2015; Short, et al., 2018). As a consequence, several fish stocks have declined dramatically (Tran, et al., 2019) with a fraction of them on the verge of collapse. High poverty levels and high demand for fish protein have possibly caused fishers in these countries to use illegal methods and gears 
in the hope of harvesting abundant fish to meet their economic and dietary needs (Kawarazuka \& Béné, 2011). The harvest composition of these fishers is often dominated by juveniles (Short, et al., 2018) with an implication that a greater proportion of fish are caught without contributing to reproduction (Wootton, 1998). Unfortunately, poor fisheries management is widespread due in part to a failure in traditional management strategies (e.g., a focus on effort and catch controls; Eggert \& Greaker, 2009). This is quite evident in Ghana where fisheries are facing serious challenges and declines in yield (Ameyaw, et al., 2012; Afoakwah, Osei, \& Effah, 2018).

Ghana's marine fisheries are made of a variety of fishing gears including purse seines, beach seines, gill nets and trawl nets, and hooks and lines (Amador, et al., 2006; Akyeampong, Amador, \& Nkrumah, 2013). These are deployed at different water depths using an array of methodologies. Each type of the nets has a unique range of mesh sizes (FAO,1980; Doyi, 1984; Arizi, et al, in prep), although a mesh size of 2.5 $\mathrm{cm}$ has been prescribed as the minimum mesh size for all the kinds of fishing nets in the fisheries (Ghana Fisheries Act, 2002). The choice of the mesh sizes depends on the type and size of targeted fish species. For instance, gill nets with large mesh sizes in Ghana are designed to target large pelagic fish such as tunas whilst those with small mesh sizes are employed to largely exploit small pelagic fish such as sardinellas.

Fish production for local consumption in Ghana highly depends on landings from the artisanal fishery of the marine fisheries sector. These landings are mostly made of sardinella species. However, landings of sardinella have been dominated by juveniles in recent times (Amposah, et al., 2017; Amposah, et al., 2019). Incessant exploitation of these juveniles could potentially reduce the spawning stock biomass of the fish with 
serious repercussions for the population growth of the fish. This could in turn drive the sardinella stock into a state of collapse if immediate actions are not taken. As a first step to take such actions, fishing gears which are disproportionately exploiting the sardinella stocks below their lengths at sexual maturity $\left(L_{m}\right)$ could be identified. So far, six kinds of fishing gears which fall into three broad categories (purse seine, gill net and beach seine) have been identified in the sardinella fishery. These gears include poli, watsa, poli-watsa, ali, set net and beach seine (Arizi et al., in prep). It is however not certain which types of gears are specifically harvesting the fish before they reach their first spawning phase, although beach seine has been experimentally determined to be destructive for some key fish species other than sardinellas in Ghana (Nunoo \& Azumah, 2015).

The Government of Ghana has started imposing a one-month fishing closure on the various sectors of the marine fisheries as a pragmatic measure to curtail the declining trend of the nation's fish resources. Although this strategy is effective for protecting fish stocks, especially pelagic fish from overexploitation (Pitchford, Codling, \& Psarra, 2007), it is unlikely to be efficient if other restrictions (e.g. gear restrictions) are not instituted during the fishing season (Jennings, et al, 2001). Gear restrictions are usually implemented to prevent fishers from catching small-sized fish, egg-bearing females and unwanted fish species. One of the less-intense proxies for assessing the sustainability of a fish stock is to determine the proportions of mature and immature fish that are being harvested differentially by fishers (Froese, 2004). It is therefore important to study the interactions among the sardinella stocks and the fishing gears of Ghana to identify gears which gears are exploiting the fish below $L_{m}$. 
Akpalu (2008) shows that massive education on the destructive effects of illegal nets can increase the compliance rate of fisheries laws in Ghana. This type of education could be facilitated by providing information about gear impacts on fish stocks. To contribute scientific data for ultimate purposes of fisheries management, FAO (1990) described the demographic strategies of sardinella species by comparing their biological parameters to fishery data for better understanding of factors responsible for the instability of sardinella stocks within the western Gulf of Guinea. In addition, the research unit of the Fisheries Commission of Ghana has been collecting catch and effort data on the sardinella fishery over the years to inform management decisions. As it stands, however, there is a paucity of published data on sardinella-gear interactions in Ghana. To provide scientific advice towards management of sardinella stocks of Ghana, we sought to: (1) determine the distribution pattern of sardinellas in coastal waters of Ghana; (2) evaluate the length at sexual maturity of the fish $\left(L_{m}\right)$; (3) examine the fish catch composition by gear type and by fishing season as a proxy for fish-gear interactions using the maturity stage of the fish as a reference point; (4) determine the relative selectivity of each gear; (5) identify the gears which are exploiting sardinellas below their $L_{m}$.

\section{MATERIALS AND METHODS}

\section{Data collection}

Our work was conducted in Ghana of West Africa, from August 2017 to June 2018. Here, we monitored fish landings bi-monthly across the eight sites: Half-Assini, Axim, Elmina, Winneba, Botianor, Tema, Keta and Denu (Arizi, et al. in prep). To collect data simultaneously across all the sites, we had a trained field assistant at each 
landing site. Each field assistant first sought consent to examine the catch of fishermen who had just returned from a fishing expedition. To ascertain the sizes of sardinellas being exploited by the fishers in Ghana, fish were measured to the nearest $0.01 \mathrm{~cm}$ for total length. We then dissected each fish specimen and examined its gonad macroscopically to determine the maturity stage (mature or immature) of the fish (Tsikliras, Stergiou, \& Froese, 2013). To properly account for the different mesh sizes of gear types in the sardinella fishery, we measured the stretched mesh size(s) of each fishing captain's net. To determine the distribution pattern of the two sardinellas in the coastal waters of Ghana, we strategically asked the fishermen to provide the depth of their fishing locations. If fishermen could not state the depth of their fishing location, no fish samples were taken from them $(<1 \%)$.

\section{Data analysis}

We compiled the catch data to determine the occurrence of each sardinella species at each fishing location. Among simple linear regression model, generalized linear model (GLM), gamma additive model (GAM), we selected the linear regression model as the best fit based on Akaike Information Criterion (Akaike, 1974) to fit the depth-catch data to establish the relationship between depth and occurrence of sardinella species. The depth of fishing location was converted into categorical variable with 10$\mathrm{m}$ bins and a two-way analysis of variance (ANOVA) method was used to determine whether the fish length of both species in the catch differed significantly among different depths $($ alpha $=0.05)$. To determine the length at first sexual maturity $\left(L_{m}\right)$ of the fish, we fit a logistic regression to the fraction of sexually mature individuals by length as described by King (1995) and Jennings, Kaiser, \& Reynolds (2001). 
We also compiled a length-frequency data from the fish length measurements of each fish species and converted them into histograms with a 1-cm bin to ascertain the length-frequency distribution of the sardinella landings per gear type and per season. Each histogram was partitioned according to the maturity status of the fish using $L_{m}$ as a reference point. We then performed a two-way ANOVA to determine whether the length-frequency distributions of the gears and of the fishing seasons differed significantly. We checked the normality and independence of the fish length data using Q-Q plots and residual-fit plots from the ANOVA fit models because of the large sample size, $\mathrm{N}=14,088$.

To determine the relative selectivity of each active gear type, we compared the sizes of fish caught by the gear to the sizes of fish in poli-watsa which played the same role as a cover net because it captured fish of all the size-classes. Subsequently, the results of the comparison were fit to a logistic cumulative distribution function (LCDF) based on the assumption that the fish size selection of each active gear (e.g., poli, watsa and beach seine) followed a sigmoid curve (Sparre \& Venema, 1998). The size selection of the passive gears (e.g., ali and set net) was assumed to follow a domed-shaped curve, hence we used the normal probability density function (NPDF) to model their selectivity by comparing the fish sizes in the catches of two passive gear types (ali and set net) as described by Holt (1963) and Sparre \& Venema (1998).

\section{RESULTS}

The occurrence of S. maderensis individuals and the depth of fishing locations were linearly related $(\mathrm{p}<0.05)$ indicating that $S$. maderensis inhabits coastal waters of up to approximately $65 \mathrm{~m}$ in depth (Fig. 7A). The occurrence of $S$. aurita and the depth 
of fishing locations were not related $(\mathrm{P}>0.05)$ as shown in Fig. 7B. There were statistical differences in the total lengths of $S$. maderensis and $S$. aurita among different depths of fishing locations in coastal waters of Ghana $F(6,95)=75.43, p<0.05$ indicating that the fish lengths for both sardinella species depend on the depth of the fishing locations (Table 1).

The total length at first sexual maturity $\left(L_{m}\right)$ for both sexes of $S$. maderensis was $15.3 \mathrm{~cm} \pm 0.013$ (Fig. 8A) and that of $S$. aurita to be $14.2 \mathrm{~cm} \pm 0.004$ (Fig. 8B) suggesting that $50 \%$ of flat sardinella individuals measuring about $15.0 \mathrm{~cm}$ and above are sexually mature whereas $50 \%$ of round sardinella individuals with a total length of about $14.0 \mathrm{~cm}$ and above are mature.

The modal lengths of $S$. maderensis and $S$. aurita per gear type determined from the length-frequency distribution in the catch (Fig. 9) are presented in Table 2. The lengths of the sardinella species differed significantly among the gears, $F(5,95)$ $=3793.15, p<0.005$. Similarly, the modal lengths of $S$. maderensis and $S$. aurita per season determined from the length-frequency distribution in the catch (Fig. 10) are presented in Table 3. The juveniles of the two fish were mostly abundant in October and February. Analysis of variance (ANOVA) showed that the lengths of the sardinellas differed significantly among the seasons, $F(5,95)=478.90, p<0.005$.

Individual landings of $S$. maderensis and of $S$. aurita in the poli, poli-watsa, set net and beach seine fisheries composed of more than $50 \%$ immature fish (Fig. 11) indicating that more immature sardinella fish are exploited by poli, poli-watsa, set net and beach seine in Ghana. In contrast, more than $50 \%$ of individual sardinella landings 
in the ali and watsa fisheries were adult fish suggesting that mature sardinella fish are mainly harvested by ali and watsa in Ghana.

Juveniles were landed in the sardinella fishery of Ghana throughout the year (Fig. 12) indicating that recruitment of young ones into the fishery may occur all yearround. Approximately, $86 \%$ of $S$. aurita landed in February and 72\% in October were juveniles, an indication of high abundance of $S$. aurita juveniles in coastal waters of Ghana in these periods. Approximately $60 \%$ of adult $S$. aurita were however landed in June and in December, an indication of high abundance of S. aurita adults in coastal waters of Ghana in June and December. The results also showed an increasing order of mature fish occurrence in the S. aurita landings in February (14\%), April (47\%) and June $(59 \%)$ corresponding to a decreasing order of $86 \%, 53 \%$ and $41 \%$ immature fish in the landings suggesting a possible growth of the juveniles into the adult stage during these periods. We also observed a general decrease in the occurrence of mature individuals after August until December as against an increase in the frequency of juveniles in the same period.

Similarly, $85 \%$ of flat sardinella landed in February and $91 \%$ in October were juveniles but about $60 \%$ of adult flat sardinella were landed in August. The results also showed an increasing order of mature fish occurrence in the flat sardinella landings in February (14\%), April (16\%) and June (28\%) matching up with a decreasing order of $86 \%, 84 \%$ and $72 \%$ occurrence of juveniles in the landings indicating a possible growth of the juveniles into the adult phase. The increasing order in the abundance of mature $S$. aurita until June with a decline in August as against a similar pattern that occurred in $S$. 
maderensis but with a peak in August followed by a decline in October suggests that $S$. aurita commences its major spawning activity before S. maderensis does so.

Sardinella individuals with a mean total length below $L_{m}$ were generally landed in the beach seine, poli, poli-watsa and set net fisheries during the study period (Fig. 13). This pattern was more pronounced in the beach seine fishery. On the contrary, sardinella individuals with a mean total length above or around $L_{m}$ were observed in both ali and watsa fisheries.

The interaction effects of gear type, fishing season (period) and depth of fishing location were found to have a significant impact on the sizes of fish landed in the sardinella fishery of Ghana $(\mathrm{P}<0.05)$ as presented in Table 4 . This interaction indicates that fishers in different gear fisheries are catching different sizes of the two sardinella species at different depths and in different seasons.

The average length at which $50 \%$ of each fish were being captured $\left(L_{c}\right)$ by poli, watsa and beach seine was estimated from the LCDF at: poli $(6.9 \mathrm{~cm})$, beach seine $(9.7$ $\mathrm{cm})$, watsa $(20.6 \mathrm{~cm})$. The average length caught most effectively by each passive gear $\left(L_{M E}\right)$ was estimated from NPDF at: ali $(20.4 \mathrm{~cm})$; set net $(14.4 \mathrm{~cm})$. For round sardinella, the average $L_{c}$ for each gear was computed as poli (9.9), beach seine (11.2 $\mathrm{cm})$, watsa $(23.5 \mathrm{~cm})$ whereas average $L_{M E}$ of each passive gear was estimated at: ali $(19.3 \mathrm{~cm})$; set net $(13.6 \mathrm{~cm})$. Thus, poli, beach seine and set net are catching more sardinella juveniles in Ghana.

To determine the capture probability of immature fish by each type of fishing gear in the sardinella fishery, we averaged the probabilities of mesh sizes for capturing immature fish of the two sardinella species per gear using the selectivity of each gear 
type as shown in Fig. 14. We found these probabilities in a decreasing order as: beach seine $(68 \%)>$ poli $(46 \%)>\operatorname{set}$ net $(43 \%)>$ ali $(22 \%)>$ watsa $(4 \%)$.

\section{DISCUSSION}

Our results indicate that $S$. maderensis prefers coastal waters up to $65 \mathrm{~m}$ in depth, whereas S. aurita inhabits a wider range of depths up to $500 \mathrm{~m}$. This finding builds upon that of Whitehead (1985) who observed S. maderensis to dwell in coastal waters of up to $50 \mathrm{~m}$ in depth and also found $S$. aurita to inhabit deeper waters of $350 \mathrm{~m}$ or more. One potential mechanism for this habitat partitioning is environmental tolerance. Ecologically, S. maderensis tolerates low salinities and relatively warm temperatures whereas $S$. aurita is sensitive to temperature and salinity changes (Minta, 2003). Another potential mechanism for this habitat partitioning is plankton dynamics. Evidence has shown that plankton constitute a major diet for sardinellas in the coastal waters of Ghana (Garrido \& van der Lingen, 2014). Plankton respond to changes in the environment, most notably temperature (Wiafe, et al., 2008). Globally, the impacts of climate change are getting manifested (Karl \& Trenberth, 2003; Meehl, et al., 2007). These impacts include rise in temperature, erratic rainfall, drought, sea level rise and high incidence of extreme weather conditions. The prevalence of these impacts has been widely reported in Ghana (Stanturf, et al., 2011). Here, climate change has caused shifts in zooplankton community and structure and this has in turn impacted on the dynamics of fish resources with remarkable changes to the abundance and distribution of pelagic fish species (Koranteng \& McGlade, 2001; Wiafe, et al., 2008). It is therefore conceivable that differences in environmental tolerance and climate change are responsible for the distribution of the two sardinellas in coastal waters of Ghana. 
Our findings also suggest that $50 \%$ of $S$. maderensis mature sexually at a total length of $15.3 \mathrm{~cm}$ whereas $50 \%$ of $S$. aurita mature at a total length of $14.2 \mathrm{~cm}$ in the coastal waters of Ghana. The $L_{m}$ for $S$. maderensis in this work is somewhat similar to the $15.43-15.56 \mathrm{~cm}$ reported by Osei (2015) but that of $S$. aurita is dissimilar to 16.40 $-16.74 \mathrm{~cm}$ in Osei's work. Some other reports on length at sexual maturity $\left(L_{m}\right)$ exist for round sardinella in Ghana's coastal waters: $15 \mathrm{~cm}$ fork length (FAO, 1990); $16.7-17.1$ cm (Quaatey \& Maravelias, 1999). By implication, the lengths at sexual maturity of the two species of sardinella in our study are relatively smaller than those reported previously. Several studies have shown that intense fishing quickens sexual maturation in fish (Law \& Grey, 1989; Diekmann \& Heino, 2007; Jørgensen, et al., 2007; Sharpe \& Hendry, 2009; Marty \& Rochet, 2014; Hunter, Speirs, \& Heath, 2015). As a strategy to withstand fishing pressure, heavily exploited fish stocks mature early to contribute through reproduction to sustain fish population (Wootton, 1998). Until now, fish stocks including sardinellas have been subjected to heavy exploitation in Ghana (Lazar, et al., 2016). Hence, the shortened period of sexual maturation exhibited by sardinellas in Ghana could be attributed to an ecoevolutionary response by the fish to withstand the intense fishing pressure exerted on the fish stocks, but determining this mechanism is out of the scope of our study.

S. maderensis is highly recruited into fishery by the various gears at length: poli $(9.0 \mathrm{~cm})$, beach seine $(10.0 \mathrm{~cm})$, poli-watsa $(11.0 \mathrm{~cm})$, set net $(11 \mathrm{~cm})$, watsa $(15 \mathrm{~cm})$ and ali $(20.0 \mathrm{~cm})$ whereas round sardinella is highly exploited by the same gears at length: poli $(8.0 \mathrm{~cm})$, beach seine $(7.0 \mathrm{~cm})$, poli-watsa $(10 \mathrm{~cm})$, set net $(12 \mathrm{~cm})$, watsa $(15 \mathrm{~cm})$ and ali $(19 \mathrm{~cm})$. From these findings, it is evident that both sardinella species 
enter into the watsa fishery at the same lengths, as opposed to entry into the other gear fisheries at different sizes. These findings seem to generally suggest that high recruitment of $S$. maderensis into most of the gears occurs at lengths of a few centimeters longer than $S$. aurita. Morphologically, there are dissimilarities in the body forms of the two sardinella species; the body of round sardinella has been described as subcylindrical and slightly compressed with a rounded belly whilst that of flat sardinella has been observed to be dorsal-ventrally compressed with a protruding belly (Whitehead, 1985). In addition, studies have shown that flat sardinella grows bigger than round sardinella (Koranteng, 1989; Osei, 2015; Arizi et al., in prep). The morphological differences and the growth patterns of the fish could explain the massive entry of the two fish into the same gear at different lengths.

Length-frequency distribution of fish landings in commercial fisheries is increasingly used as a magement tool to assess the fishery status (Clement, Pangle, \& Uzarski, 2014). If fish stocks are exploited below sustainable limits with landings dominated by mature fish, the fishery is likely to be sustainable but if fish stocks are exploited above sustainable limits with fish landings dominated by immature fish, the fishery is likely to be unsustainable (Barausse, et al., 2014; Restrepo, Zimmerman, \& Barz, 2015). On this basis, the sardinella fishery of Ghana could be described as unsustainable because the fish stocks are being exploited beyond sustainable levels and the landings as evidenced in this work are dominated by immature fish.

Fishers in the ali and watsa fisheries are harvesting more mature individuals of sardinellas whereas those in the poli, poli-watsa, beach seine and set net fisheries are landing more immature sardinellas in Ghana. Doyi (1984) reported smaller mesh sizes 
for poli but larger mesh sizes for watsa and ali. This has been recently confirmed by Arizi et al, (in prep) that poli-watsa, set net and beach seine have relatively small mesh sizes. Regulation of mesh sizes of fishing nets could be used to control fish size of catches with a consequent change of motality rates at fish length. To achieve this regulation, knowledge about the selectivity of each net is needed to match the mesh size of the net to the degree of escapment (Jennings, Kaiser, \& Reynolds, 2001). We therefore examined the relative selectivity of these gears and the results revealed that that watsa and ali are size-selective whilst the rest of the nets catch fish of all sizes. The present study has revealed that beach seine has the greatest probability of capturing juveniles. In Ghana, the landing of a beach seine is mostly determined by the catch in its codend, although the wings of the net are equipped with net materials of different mesh sizes. On this basis, only the mesh sizes of the codend of beach seine were considered to determine the capture probability in this work. This might have contributed to the highest probability of immature fish capture for beach seines in Ghana.

Our findings also showed that the adult individuals of $S$. aurita were abundant in June and in December whereas those of S. maderensis were in August. FAO (1992) asserts that mature adults of both species in inshore waters of Ghana at a specific season is an indication that the two sardinellas use the inshore waters of Ghana as their spawning grounds. S. maderensis spawns once a year (Minta, 2003) whereas S. aurita spawns more than once in a year (Koranteng, 1989). High numbers of adult S. aurita fish observed in June and in December suggest that there are two pronounced spawning seasons for the fish. On the contrary, high number of adult S. maderensis in August 
suggests that an outstanding spawning activity occurs in August for the fish. Due to the presence of juveniles of in the landings throughout the year, it is difficult to support the claim of Minta because a study conducted by Osei (2015) revealed two pronounced recruitment seasons for $S$. maderensis in Ghana. Our understanding of the annual spawning activities of the fish in this study is limited by the bi-monthly data.

The total length at first sexual maturity $\left(L_{m}\right)$ is an important index for determing the spawning biomass of a fish population. Fisheries whose fish stocks are below $L_{m}$ are considered unsustainable, especially when recruitment into the population is less than what is harvested. On this basis, we examined the mean sizes of sardinellas landed per each gear and our results demonstrate that poli, poli-watsa, set net and beach seine are exploiting the sardinellas below $L_{m}$ with the worse-case scenario emanating from the beach seine fishery. This suggests that many sardinellas have their first spawning activity thwarted throughout the year. Four out of the six kinds of fishing gears which are catching a greater proportion of immature fish in the sardinella fishery of Ghana also render the fishery unsustainable. Nunoo and Azumah (2015) have found a 2.5-cm codend (bunt) of a beach seine to be both ecologically and financially sustainable. As ali and watsa with large mesh sizes have been proven to select relatively big fish that are also mature, we recommend that the mesh sizes of poli, poli-watsa, set net and beach seine should be adjusted upwardly to meet the requirements of the minimum mesh size $(2.5 \mathrm{~cm})$ enshrined in the fisheries act of Ghana.

Fishers in the sardinella fishery of Ghana are using different gears to catch different sizes of the two sardinella species at different depths and in different seasons. Gears with diverse mesh sizes select fish differentially (Clement, Pangle, \& Uzarski, 
2014). The selection of fish depends on the size and shape of the fish. Studies have demonstrated that the mesh sizes of the gears in the sardinella fishery of Ghana are at variance with one another (FAO, 1980; Doyi, 1984). In this study, we have also shown that these gears have different probabilities of capturing sardinellas at different lengths. The differential selection of fish sizes per gear could be attributed to the different mesh sizes possessed by the gears vis-à-vis the differences in the body forms of the two species. Horizontal segregation between different sizes of fish in shallow and deep waters has been reported in certain fish species such as herrings (Petrakis, MacLennan, \& Newton, 2001). Kim, et al. (2006) have shown that juveniles of certain species of sardines prefer to inhabit shallow waters to complete the juvenile stage of their life but as growth occurs they move to deeper waters to spend the rest of their life. Older age groups of round sardinella in the waters of Ghana have been reported to dwell in offshore or deeper waters for the greater part of the year but occasionally migrate to inshore or shallower waters to spawn during cold temperatures; however, migration of flat sardinella is limited to inshore waters (Cury \& Fontana, 1988). Therefore, differential selection of fish sizes per depth of fishing location could be ascribed to habitat partitioning of species and by life stages of the fish.

Sardinellas in the coastal waters of Ghana spawn throughout the year (Osei, 2015). A study conduted by Quaatey and Maravelias (1999) revealed that round sardinella spawns in batches. Although, no study has confirmed this reproductive trait in flat sardinella, the appearance of mature individuals of the fish in the landings that is somewhat likened to that of round sardinella as presented in this work shows that flat sardinella possibly spawns in batches as well. The regular spawning activities of 
sardinellas with attendant regular recruitment of young individuals into the fish stocks might have accounted for the disproportional selection of fish sizes per the fishing periods. The high significance of sardinella-gear interactions in this work is an indication that the interactions are worthy of study from time to time so as to contribute knowledge towards a deeper understanding of the sardinella fishery dynamics in Ghana.

\section{CONCLUSIONS}

In summary, our study shows that flat sardinella dwells in coastal waters up to $65 \mathrm{~m}$ in depth whereas round sardinella inhabits waters of depth up to approximately $500 \mathrm{~m}$. About $50 \%$ of flat sardinella sexually mature at a total length of $15.3 \mathrm{~cm}$ whereas $50 \%$ of round sardinella mature at a total length of $14.2 \mathrm{~cm}$ in coastal waters of Ghana.

We have also demonstrated that fishers in the sardinella fishery of Ghana are using different gears to catch different sizes of two sardinella fish at different depths in different seasons. Fishers in the ali and watsa fisheries are generally harvesting fish above $L_{m}$ suggesting that ali and watsa are catching more mature fish. On the contrary, fishers in the poli, poli-watsa, beach seine and set net fisheries are catching fish below $L_{m}$ suggesting that gears in these fisheries are harvesting more immature sardinellas in Ghana. Considering how sardinella landings are dominated by immature fish in Ghana, we recommend that the mesh sizes of poli, poli-watsa, set net and beach seine should be increased to meet the requirements of the minimum mesh size $(2.5 \mathrm{~cm})$ enshrined in the Fisheries Act of Ghana. This management measure in conjunction with seasonal closure proposed by the Government of Ghana could help to create a potential pathway for sustainability in the sardinella fishery of Ghana. 


\section{ACKNOWLEDGEMENT}

We are thankful to USAID for funding this research through the Ghana Sustainable Fisheries Management Project (SFMP). The contributions from the anonymous field assistants are highly appreciated. 


\section{REFERENCES}

Adimey, N. M., Hudak, C., Powell, J. R., Bassos-Hull, K., Foley, A., Farmer, N. A., . . . Minch, K. (2014). Fishery gear interactions from stranded bottlenose dolphins, Florida manatees and sea turtles in Florida, U.S.A. Marine Pollution Bulletin(81), 103 - 115.

Afoakwah, R., Osei, M., \& Effah, E. (2018). A guide to illegal fishing activities in Ghana. University of Rhode Island, Graduate School of Oceanography, Coastal Resources Center. Narragansett: University of Rhode Island.

Akaike, H. (1974). A new look at the statistical model identification. IEEE Transactions on Automatic Control, 19(6), 716 - 723.

Akpalu, W. (2008). Fishing regulations, individual discount rate and fisherman behaviour in a developing country fishery. Environment and Development Economics, 13(05), $591-606$.

Akyeampong, S., Amador, K., \& Nkrumah, B. (2013). Report on the 2013 Ghana marine canoe frame survey. Ministry of Fisheries and Aquaculture Development, Fisheries Commission, Fisheries Scientific Survey Division. Accra: Republic of Ghana.

Amador, K., Bannerman, P., Quartey, R., \& Ashong, R. (2006). Ghana canoe frame survey. Ministry of Food and Agriculture, Marine Fisheries Research Division. Accra: Republic of Ghana.

Ameyaw, G., Asare, C., Mutimukuru-Maravanyika, T., Laryea, J., Sabah, A., \& Mills, D. J. (2012). Fisheries law and regulations in Ghana. University of Rhode 
Island, Graduate School of Oceanography, Coastal Resources Center. Narragansett, RI: University of Rhode Island.

Amposah, S. K., Ofori-Danson, P., Nunoo, F., \& Ameyaw, G. A. (2017). Population Dynamics of Sardinella aurita (Val., 1847) within Ghana's Coastal Waters. Research in Agriculture, livestock and fisheries, 4(3), 237 - 248.

Amposah, S., Ofori-Danson, P., Nunoo, K. E., \& Ameyaw, G. (2019). Estimates of population parameters for Sardinella maderensis (Lowe, 1838) in the coastal waters of Ghana. Greener Journal of Agriculture Sciences, 1(9), 23-31.

Barausse, A., Correale, V., Curkovic, A., Finotto, L., Riginella, E., Visentin, E., \& Mazzoldi, C. (2014). The role of fisheries and the environment in driving the decline of elasmobranchs in the northern Adriatic Sea. ICES Journal of Marine Science, 71(7), 1593 - 1603.

Benjamins, S., Ledwell, W., Huntington, J., \& Davidson, A. (2012). Assessing changes in numbers and distribution of large whale entanglements in Newfoundland and Labrador. Marine Mammal Science, 3(28), 579 - 601.

Buxton, C. D. (1993). Life-history changes in exploited reef fishes on the east coast of South Africa. Environmental Biology of Fishes(36), 47 - 63.

Cardoso, I., Moura, T., Mendes, H., Silva, C., \& Azevedo, M. (2015). An ecosystem approach to mixed fisheries: technical and biological interactions in the Portuguese multi-gear fleet. ICES Journal of Marine Science, 72(9), 2618 2626.

Cashion, T., Al-Abdulrazzak, D., Belhabib, D., Derrick, B., Divovich, E., Moutopolos, D. K., . . Pauly, D. (2018). Reconstructing global marine fishing gear use: 
catches and landed values by gear type and sector. Fisheries Research(206), 57 $-64$.

Clement, T., Pangle, K., \& Uzarski, D. (2014). Effectiveness of fishing gears to assess fish assemblage size structure in small lake ecosystems. Fisheries Management and Ecology(21), 211 - 219.

Crespo, G., \& Dunn, D. (2017). A review of the impacts of fisheries on open-ocean ecosystems. ICES Journal of Marine Science, 9(74), 2283 - 2297.

Cury, P., \& Fontana, A. (1988). Compétition et stratégies démo-graphiques compares de deux especés de sardinelles (sardinella aurita et sardinella maderensis) des cotes oust africaines. Aquatic Living Resources(1), 165 - 180.

Diekmann, U., \& Heino, M. (2007). Probabilistic maturation reaction norms: their history, strengths, and limitations. Marine Ecological Progress Series(335), 253 $-269$.

Doyi, B. (1984). Catalogue of small-scale fishing gear in Ghana. Rome: FAO.

Dulvy, N., Metcalfe, J., Glanville, J., Pawson, M., \& Reynolds, J. (2000). Fishery stability, local extinctions and shifts in community structure in skates. Conservation Biology(14), 283 - 293.

Eggert, H., \& Greaker, M. (2009). Effects of global fisheries on developing countries. Environment for Development.

FAO. (1980). Report of the ad hoc working group on Sardinella off the Coast of Ivory Coast - Ghana - Togo. Food and Agriculture Organization of the United Nations., Publications Division. Rome: FAO. 
FAO. (1990). Report of the technical consultation on small pelagic species of the statistical division western Gulf of Guinea. FAO, Oceanographic Research Center. Rome: FAO.

FAO. (1992). Report of the ad hoc Working Group on the Coastal Pelagic Stocks of the Western Gulf of Guinea (Côte d'Ivoire, Ghana, Togo, Benin), held at the Centre de Recherches Océanographique, Abidjan, Côte d'Ivoire, 10-16 December. FAO. Rome: FAO.

Froese, R. (2004). Keep it simple: three indicators to deal with overfishing. Fish and Fisheries(5), 86 - 91.

Garrido, S., \& van der Lingen, C. (2014). Feeding biology and ecology. In K. Ganias, Biology and ecology of sardines and anchovies. Boca Raton, Florida, USA: CRC Press.

Ghana Fisheries Act, 2002, GPC/A667/300/12/2001 (Ghana Government Printer, Assembly Press May 17, 2002).

Holt, S. J. (1963). A method of determining gear selectivity and its application. ICNAF Special Publications(5), $106-115$.

Hunter, A., Speirs, D. C., \& Heath, M. (2015). Fishery-induced changes to age and length dependent maturation schedules of three demersal fish species in the Firth of Clyde. Fisheries Research(170), 14-23.

Jørgensen, C., Enberg, K., Dunlop, E. S., Arlinghaus, R., Boukal, D. S., Brander, K., , . . Rijnsdorp, A. (2007). Managing eveolution fish stocks. Science(318), 1247.

Jennings, S., Kaiser, M. J., \& Reynolds, J. D. (2001). Marine Fisheries Ecology. Oxford, UK: Blackwell Science Ltd. 
Karl, T. R., \& Trenberth, K. (2003). Modern global climate change. Science(302), 1719 $-1723$.

Kawarazuka, N., \& Bene, C. (2011). The potential role of small fish species in improving micronutrient deficiences in developing countries:building evidence. Public Health Nutrition, 14(11), 1927 - 1938.

Kim, J. Y., Kim, S., Choi, Y., \& Lee, J. B. (2006). Evidence of density-dependent effects on population variation of Japanese sardine (Sardinops melanosticta) off Korea. Fisheries Oceanography, 4(15), 345 - 349.

King, M. (1995). Fisheries biology assessment and management. Oxford: Blackwell Publishing Company.

Knowlton, A., \& Kraus, S. (2001). Mortality and serious injury of nothern right whales (Eubalaena glacialis) in the western North Atlantic Ocean. Journal of Cetacean Research and Management(2), 193 - 208.

Koranteng, K. A. (1989). The sardinella (herring) fishery in Ghana, that past, recent development and the years ahead. Fisheries Department. Tema, Ghana: Reseach and Utilization Branch.

Koranteng, K., \& McGlade, J. (2001). Climatic trends in continental shelf waters off Ghana and in the Gulf of Guinea, 1963-1992. Oceanologica Acta, 2(24), 187198.

Law, R., \& Grey, D. R. (1989). Evolution of yields from populations with age-specific cropping. Evolutionary Ecology(3), 343 - 359.

Lazar, N., Yankson, K., Blay, J., Ofori-Danson, P., Markwei, P., Agbogah, K., ... . Bilisini, W. (2016). Rebuilding depleted small pelagic stocks in Ghana. A closed 
fishing season proposal to the Ministry of Fisheries and Aquaculture Development. University of Rhode Island, Graduate School of Oceanography, Caostal Resources Center. Narragansett, RI: University of Rhode Island.

Marty, L., \& Rochet, M. (2014). Temporal trends in age and size at maturation of four North Sea gadid species: cod, haddock, whiting and Norway pout. Marine Ecology Progress Series(497), 179-197.

Meehl, G. A., Stocker, T. F., Collins, W. D., Friedlingstein, P., Gaye, T., Gregory, J., . . Zhao, Z. C. (2007). Global climate projections. In S. Solomon, D. Qin, M. Manning, Z. Chen, M. Marquis, K. Averyt, ... H. Miller, IPCC, 2007: Climate Change 2007: the physical science basis. Contribution of Working Group I to the Fourth Assessment Report of the Intergovernmental Panel on Climate Change. . Cambridge, U. K.: Cambridge University Press.

Minta, S. O. (2003). Assessment of the vulnerability of Ghana's coastal artisanal fishery to climate change. University of TrØmso, Department of Aquatic Biosciences, Norwegian College of Fishery . TrØmso, Norway: University of TrØmso.

Nunoo, F., \& Azumah, D. Y. (2015). Selectivity studies on beach seine deployed in nearshore waters near Accra, Ghana. International Journal of Fisheries and Aquaculture, 7(7), 111 - 126.

Osei, I. (2015). Aspects of the biology of Sardinella aurita and Sardinella maderensis (Clupeidae) in the coastal waters of the Central Region, Ghana. University of Cape Coast. University of Cape Coast. 
Petrakis, G., MacLennan, D. N., \& Newton, A. W. (2001). Day-night and depth effects on catch rates during trawl surveys in the North Sea. ICES Journal of Marine Science(58), 50 - 60.

Pitchford, J., Codling, E., \& Psarra, D. (2007). Uncertainty and sustainability in fisheries and the benefits of marine protected areas. Ecological Modelling(207), 286 292.

Purcell, S. W., \& Pomeroy, R. S. (2015). Driving samll-scale fisheries in developing countries. Frontiers in Marine Science, 2(44).

Quaatey, S., \& Maravelias, C. (1999). Maturity and spawning pattern of Sardinella aurita in relation to water temperature and zooplankton abundance off Ghana, West Africa. Journal of Applied Ichthyology(15), 63-69.

Restrepo, V., Zimmerman, C., \& Barz, K. (2015). Is catching fish truly unsustainable?

Sadovy, Y. J. (1996). Reproduction of reef fishery speices. In N. Polunin, \& C. Roberts, Reef Fisheries (pp. 15 - 59). London: Chapman \& Hall.

Sharpe, D., \& Hendry, A. (2009). Life history change in commercially exploited fish stocks: an analysis of trends across studies. Evolutionary Applications(2), 260275.

Short, R., Gurung, R., Rowcliffe, M., Hill, N., \& Milner-Gulland, E. J. (2018). The use of mosquito nets in fisheries: A global perspective. Plos One, 1(13).

Smith, B. D., Francis, R., \& McVeagh, M. (1991). Loss of genetic diversity due to fishing pressure. Fisheries Research(10), 309 - 316.

Sparre, P., \& Venema, S. C. (1998). Introduction to tropical fish stock assessment. Part 1 manual. Rome: FAO. 
Stanturf, J., Warren, M., Charnley, S., Polasky, S., Goodrick, S., Armah, F., \& Nyako, Y. (2011). Ghana climate change vulnerability and adaptation assessment.

Thompson, R., \& Munro, J. (1983). The biology, ecology and bionomics of the hinds and groupers, Serranidae. ICLARM Studies and Reviews(7), 59 - 81.

Toresen, R. (1990). Long-term changes in growth of Norwegian spring spawning herring. Journal du Conseil, Conseil International pour l'Exploration de la Mer $(47), 48-56$.

Tran, N., Chu, L., Chan, C., Genschick, S., Philips, M. J., \& Kefi, A. S. (2019). Fish supply and demand for food security in Sub-Saharan Africa: an anlysis of the Zambian fish sector. Marine Policy (99), 343-350.

Tsikliras, A., Stergiou, K., \& Froese, R. (2013). Editorial note on reproductive biology of fishes. Acta Ichthyologica et Piscatoria, 1(43), 1-5.

Whitehead, P. (1985). FAO species catalogue. Vol. 7.Clupeiod fishes of the world. An annotated and illustrated catalogue of herrings, sardines, plichards, sprat, anchovies and wolf-herrings. Part 1 - Chirocentridae, Clupeidae and Pristigasteridae. Rome: FAO.

Wiafe, G., Yaqub, H., Mensah, M., \& Frid, C. (2008). Impact of climate change on long-term zooplankton biomass in the upwelling region of the Gulf of Guinea. ICES Journal of Marine Science(65), 318-324.

Wootton, R. J. (1998). Ecology of teleost fishes. Dordrecht, Netherlands: Kluwer Academic Publishers. 


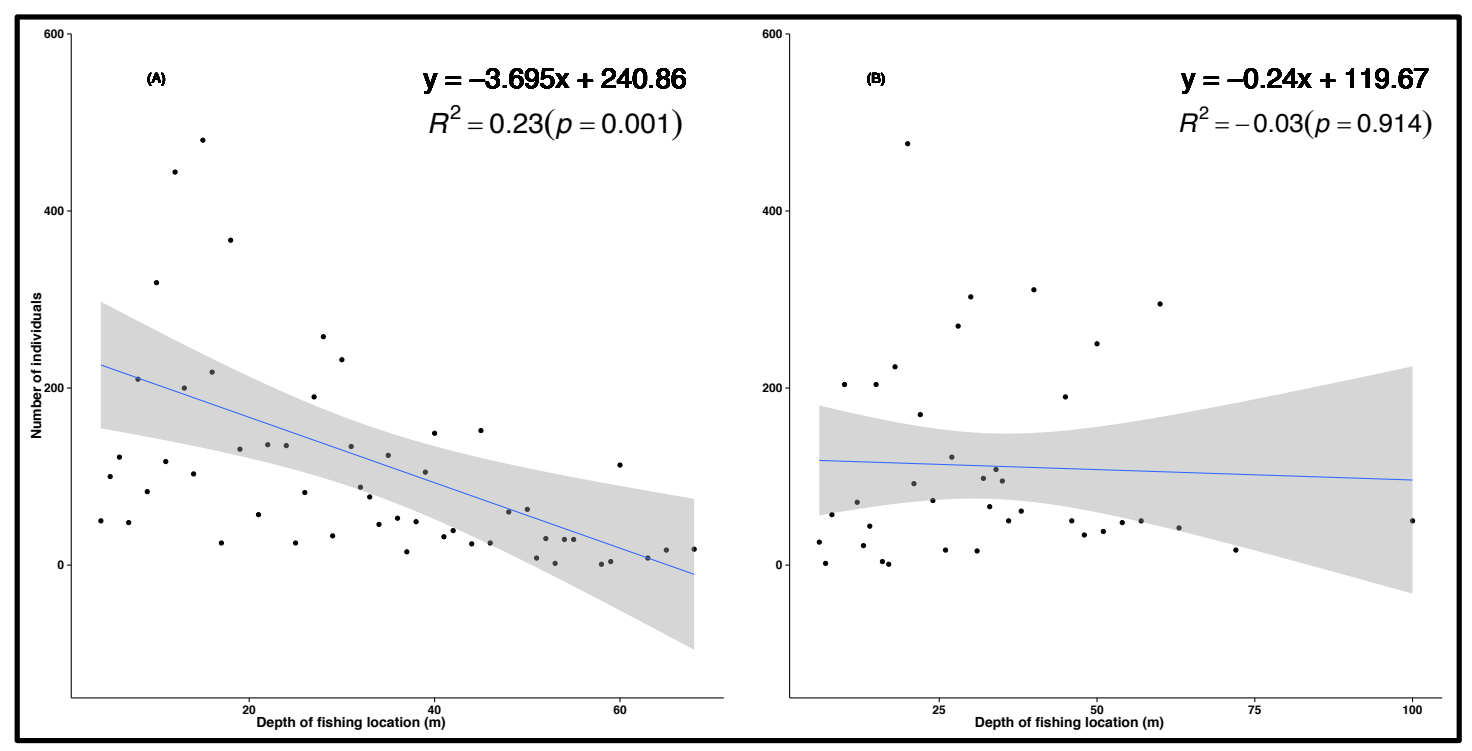

Fig. 7. Relationship between depth of fishing location and occurrence of (A) $S$. maderensis and (B) S. aurita within the coastal waters of Ghana 


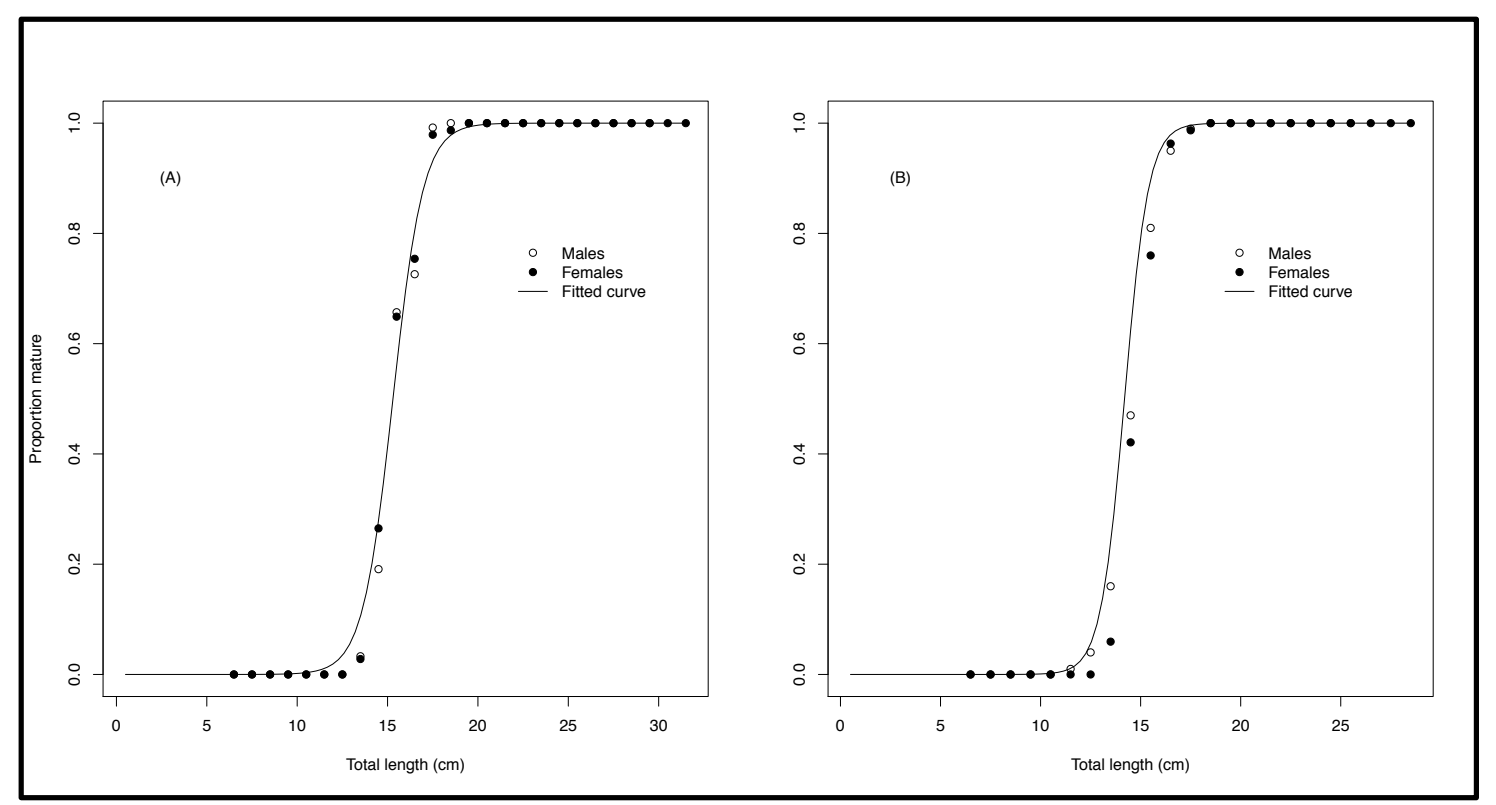

Fig. 8. Length-based proportions of sexual maturity for (A) S. maderensis and (B) $S$. aurita in the marine waters of Ghana 


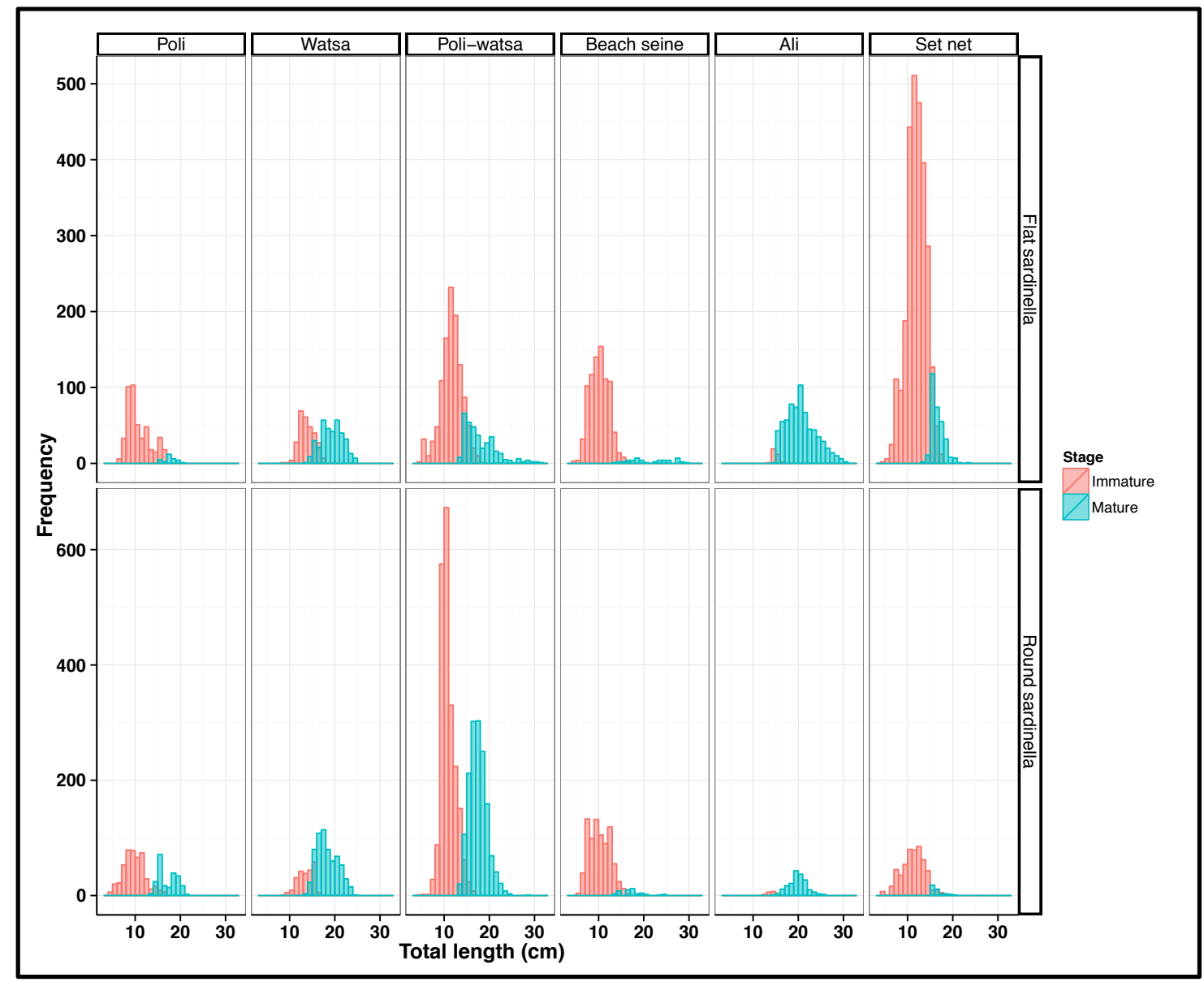

Fig. 9. Length-frequency distributions of sardinella caught by the various gears in the marine fisheries of Ghana 


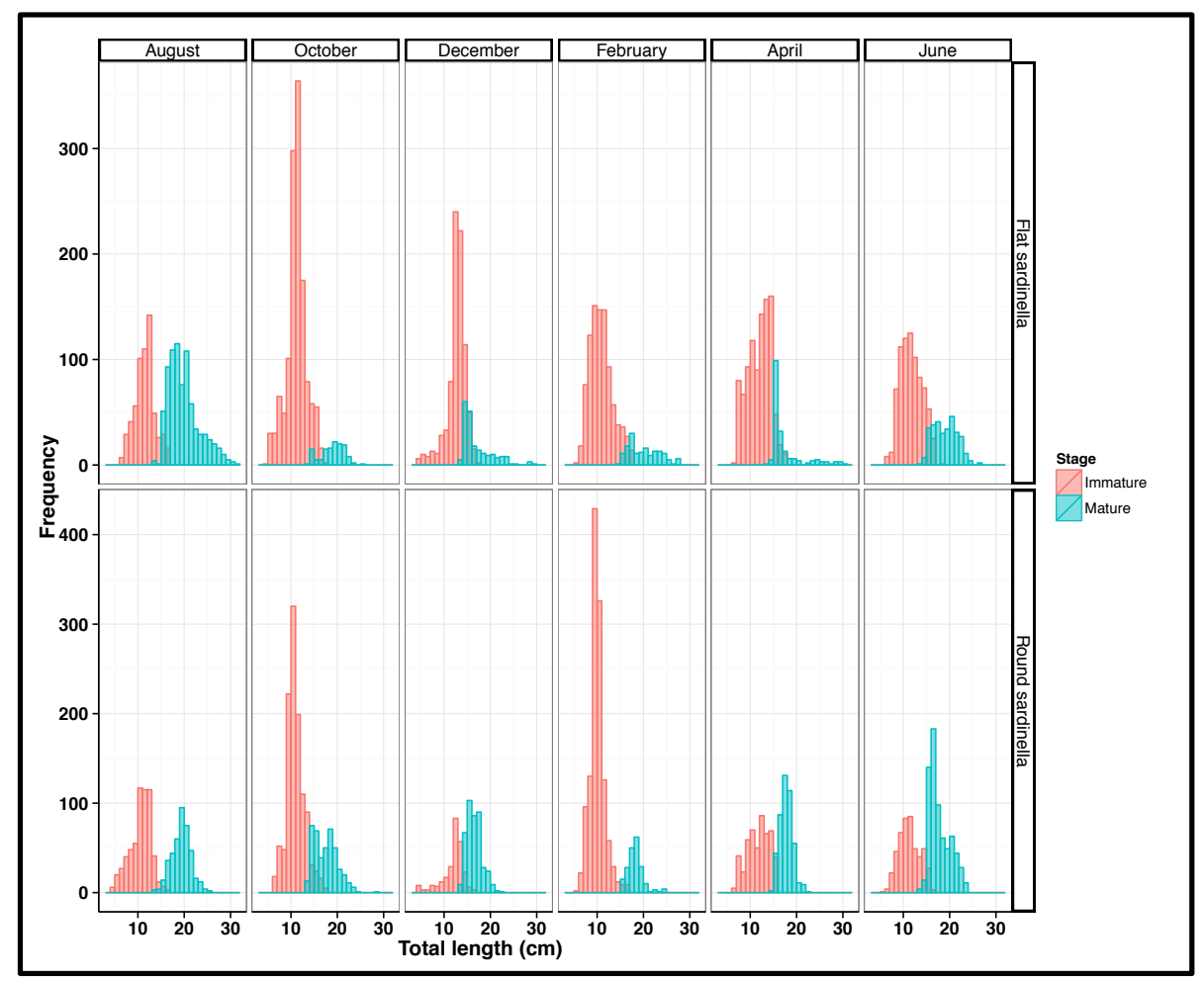

Fig. 10. Bi-monthly length-frequency distributions of flat sardinella and round sardinella in the marine fisheries of Ghana 


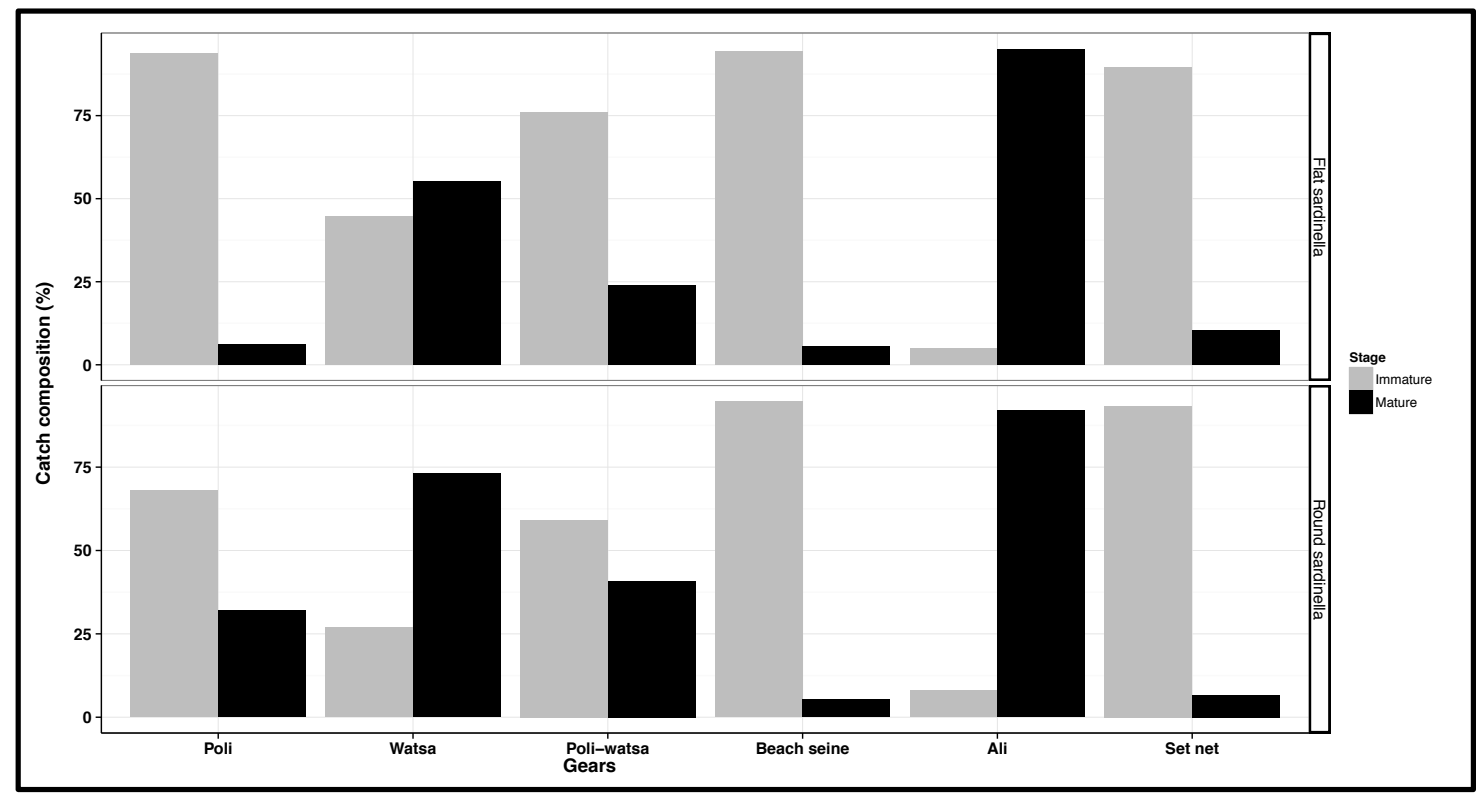

Fig. 11. Proportions of mature and immature fish per gear type in the sardinella fishery of Ghana 


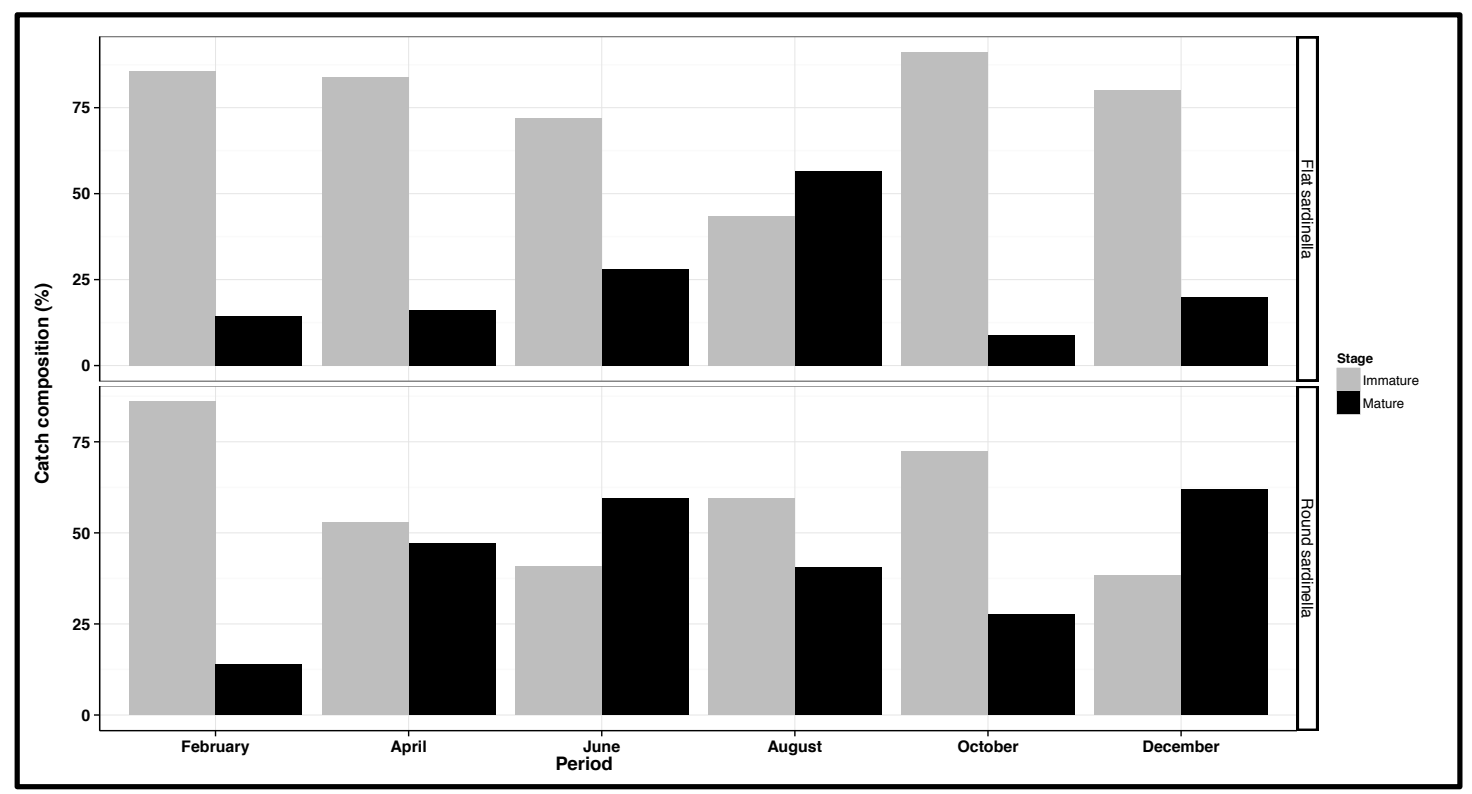

Fig. 12. Proportions of mature and immature fish per fishing season in the sardinella

fishery of Ghana 


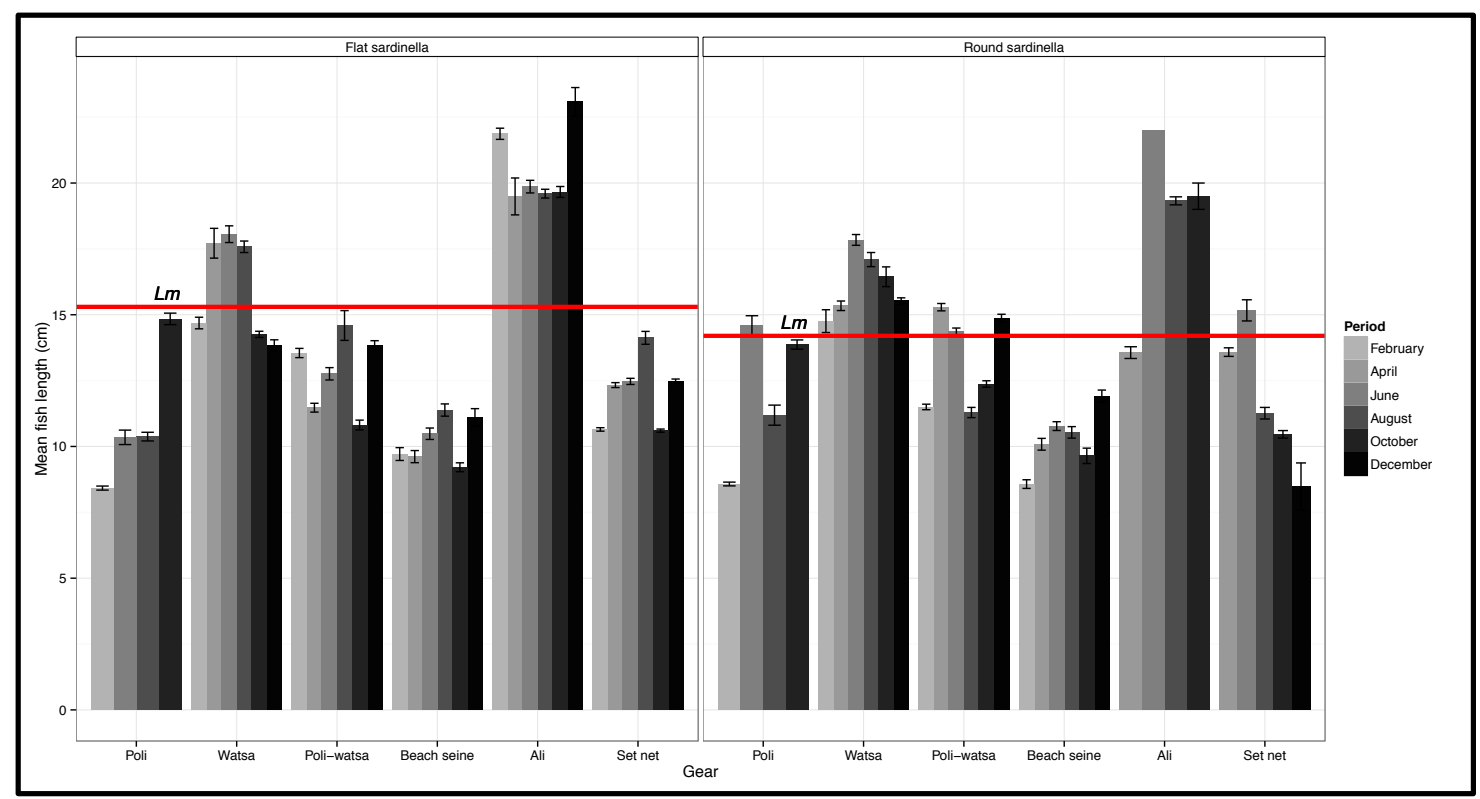

Fig. 13. Bi-monthly mean size of S. maderensis and S. aurita landed per each kind of fishing gear in the marine fisheries of Ghana. Red line represents length at first sexual maturity $\left(L_{m}\right)$ 


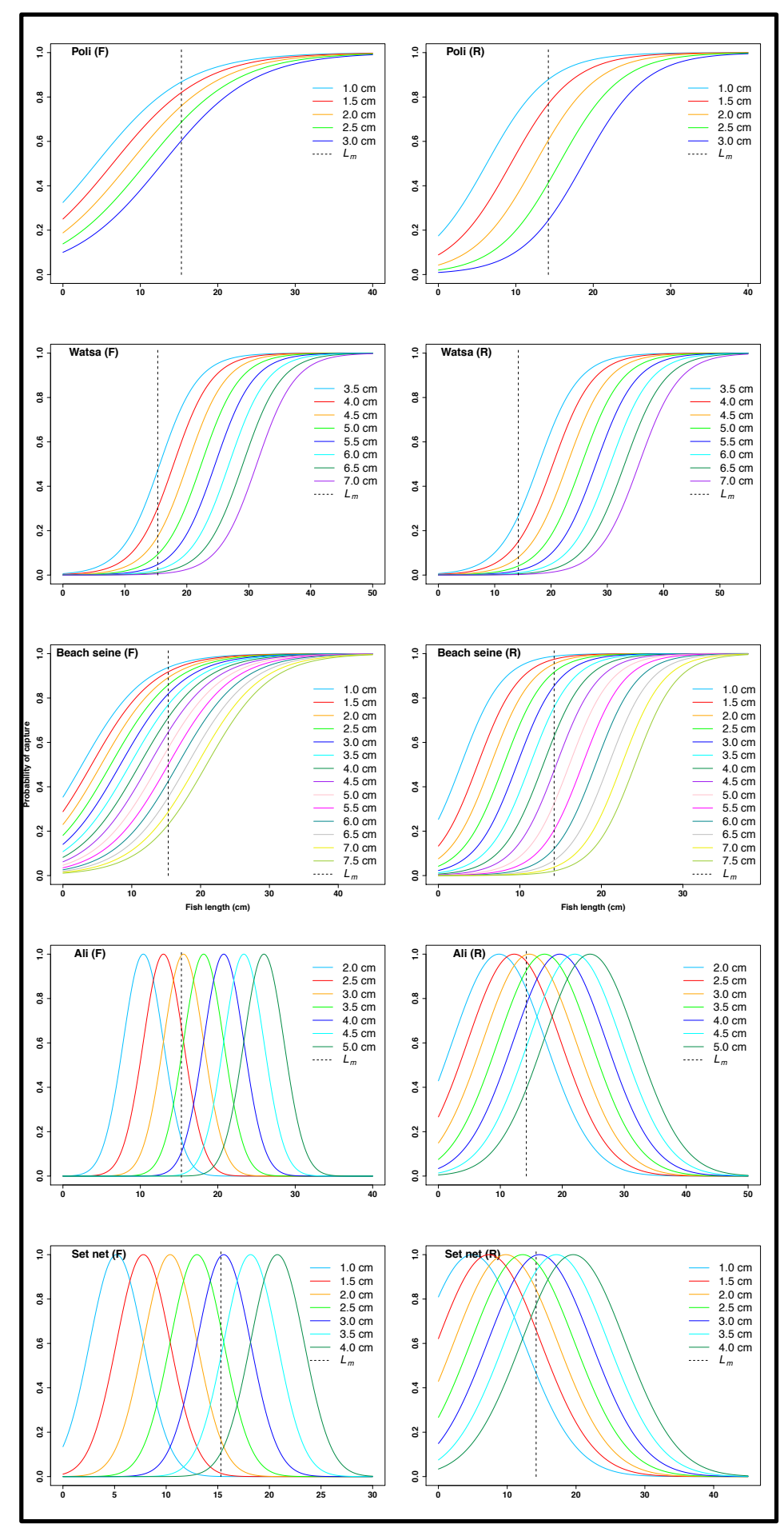

Fig. 14. Selection curves for the various types of fishing nets excluding poli-watsa in the sardinella fishery of Ghana. (F) denotes flat sardinella whereas (R) represents round sardinella. Black dotted lines indicate length at first sexual maturity $\left(L_{m}\right)$ 
Table 1. ANOVA table showing statistical differences in the total lengths of Sardinella maderensis and Sardinella aurita among different depths of fishing locations in coastal waters of Ghana

\begin{tabular}{|c|c|c|c|c|c|c|}
\hline $\begin{array}{l}\text { Response } \\
\text { variable }\end{array}$ & $\begin{array}{l}\text { Categorical variables and } \\
\text { their interactions }\end{array}$ & df & $\mathbf{S S}$ & MS & $\mathbf{F}$ & $\mathbf{P}$ \\
\hline \multirow[t]{3}{*}{ Total length } & Species & 1 & 246 & 245.7 & 17.26 & $0.000^{* * *}$ \\
\hline & Depths fished & 9 & 16881 & 1875.7 & 131.75 & $0.000^{* * *}$ \\
\hline & Species * depths fished & 6 & 6443 & 1073.8 & 75.43 & $0.000^{* * *}$ \\
\hline
\end{tabular}


Table 2. Modal length of fish in the catch of each fishing gear

\begin{tabular}{lcc}
\hline Gear & \multicolumn{2}{c}{ Modal length of fish in the catch (cm) } \\
& S. maderensis & S. aurita \\
\hline Poli & $9.0-9.9$ & $8.0-8.9$ \\
Watsa & $15.0-15.9$ & $15.0-15.9$ \\
Poli-watsa & $11.0-11.9$ & $10.0-10.9$ \\
Beach seine & $10.0-10.9$ & $7.0-7.9$ \\
Ali & $20.0-20.9$ & $19.0-19.9$ \\
Set net & $11.0-11.9$ & $12.0-12.9$ \\
\hline
\end{tabular}


Table 3. Modal length of fish in the catch per season

\begin{tabular}{lcc}
\hline Month & \multicolumn{2}{c}{ Modal length of fish in the catch (cm) } \\
& S. maderensis & S. aurita \\
\hline August & $12.0-12.9$ & $10.0-10.9$ \\
October & $11.0-11.9$ & $10.0-10.9$ \\
December & $12.0-12.9$ & $15.0-15.9$ \\
February & $9.0-9.9$ & $9.0-9.9$ \\
April & $14.0-14.9$ & $17.0-17.9$ \\
June & $11.0-11.9$ & $16.0-16.9$ \\
\hline
\end{tabular}


Table 4. ANOVA table showing the effects of gears, period of exploitation and depth of fishing location with their interaction effects on the total length of Sardinella maderensis and of Sardinella maderensis in the landings of the sardinella fishery of Ghana

\begin{tabular}{|c|c|c|c|c|c|c|}
\hline $\begin{array}{l}\text { Response } \\
\text { variable }\end{array}$ & $\begin{array}{l}\text { Categorical variables and } \\
\text { their interactions }\end{array}$ & df & SS & MS & $\mathbf{F}$ & $\mathbf{P}$ \\
\hline Total length of & Gears & 5 & 38734 & 7747 & 1003.83 & $0.000^{* * *}$ \\
\hline Sardinella & Depths fished & 7 & 2439 & 348 & 45.15 & $0.000^{* * *}$ \\
\hline \multirow[t]{7}{*}{ maderensis } & Gears * depths fished & 16 & 9259 & 579 & 74.98 & $0.000^{* * *}$ \\
\hline & Periods & 5 & 17312 & 3462 & 284.33 & $0.000^{* * *}$ \\
\hline & Depth fished & 7 & 2568 & 367 & 30.13 & $0.000^{* * *}$ \\
\hline & Periods * depths fished & 24 & 7244 & 302 & 24.79 & $0.000^{* * *}$ \\
\hline & Gears & 5 & 38734 & 7747 & 930.72 & $0.000^{* * *}$ \\
\hline & Periods & 5 & 2678 & 536 & 64.34 & $0.000^{* * *}$ \\
\hline & Gears * periods & 21 & 5863 & 279 & 33.55 & $0.000^{* * *}$ \\
\hline Total length of & Gears & 5 & 19996 & 3999 & 454.49 & $0.000^{* * *}$ \\
\hline \multirow[t]{8}{*}{ Sardinella aurita } & Depths fished & 8 & 10573 & 1322 & 150.19 & $0.000^{* * *}$ \\
\hline & Gears * depths fished & 17 & 8046 & 473 & 53.79 & $0.000^{* * *}$ \\
\hline & Periods & 5 & 7682 & 1536.5 & 167.19 & $0.000^{* * *}$ \\
\hline & Depth fished & 8 & 18633 & 2329.2 & 253.45 & $0.000^{* * *}$ \\
\hline & Periods $*$ depths fished & 24 & 10144 & 422.7 & 45.99 & $0.000^{* * *}$ \\
\hline & Gears & 5 & 19996 & 3999 & 414.44 & $0.000^{* * *}$ \\
\hline & Periods & 5 & 8210 & 1642 & 170.17 & $0.000^{* * *}$ \\
\hline & Gears * periods & 20 & 5576 & 279 & 28.89 & $0.000^{* * *}$ \\
\hline
\end{tabular}




\section{MANUSCRIPT-III}

"Modeling the Effects of Seasonal Closures and Gear Restrictions on Sardinella

Populations in the Coastal Waters of Ghana, West Africa”

by

Evans K. Arizi ${ }^{1}$; Jeremy S. Collie ${ }^{2}$; Kathleen Castro ${ }^{3}$; Austin T. Humphries ${ }^{4}$

is intended to be submitted to PLoS ONE

${ }^{1} \mathrm{PhD}$ Candidate, Department of Fisheries, Animal and Veterinary Sciences, University of Rhode Island, Kingston, RI, 02881. Email: evansarizi@my.uri.edu

${ }^{2}$ Professor, Graduate School of Oceanography, University of Rhode Island, Narragansett, RI, 02882. Email: jcollie@uri.edu

${ }^{3}$ Research Associate, Department of Fisheries, Animal and Veterinary Sciences, University of Rhode Island, Kingston, RI, 02881. Email: kcastro@uri.edu

${ }^{4}$ Professor, Department of Fisheries, Animal and Veterinary Sciences, University of Rhode Island, Kingston, RI, 02881. Email: humphries@uri.edu 


\section{ABSTRACT}

The sardinella fishery forms the backbone of Ghana's marine artisanal fisheries. There are two species in the sardinella fishery: flat sardinella (Sardinella maderensis) and round sardinella (Sardinella aurita). Catches of these fish, however, have been dwindling for the last decade due to overfishing. Yet, little research has been done to guide or inform the government of Ghana on possible outcomes from different fisheries management strategies. Hence, this study sought to explore two potential management solutions to achieve sustainable exploitation rates of the sardinella stocks. First, we determined the life-history characteristics of $S$. maderensis (7, 240 individuals) and of Sardinella aurita $(6,848$ individuals). We then simulated the population dynamics of both species under different seasonal fishing closures, with and without accompanying gear restrictions. The population growth rates of the two sardinella species ranged from $0.089-2.59 \mathrm{yr}^{-1}$ under seasonal closures without gear restrictions, as well as under seasonal closures with gear restrictions. Growth rates, however, were relatively higher under the seasonal closures with gear restrictions as compared to the seasonal closures without gear restrictions due to high recruitment of juveniles into the fishery. Although longer seasonal closures resulted in higher population growth rates, we found that a onemonth seasonal closure with gear restrictions to be the optimal management strategy. The gear restrictions would allow the fish to spawn at least once in their lifetime before they become harvestable. Under the current management status quo, our results suggest that both species will continue to dwindle and collapse within $15-20$ years. These simulations provide mangers with the tools necessary to forecast sardinella populations in Ghana under different policies, enabling sustainable management regulations to be 
established.

\section{INTRODUCTION}

Although the sardinella fishery in Ghana has a long history, it was fully developed around 1946 to provide fish protein for local consumption and to supply fisheries resources for successful operationalization of a cannery and a fishmeal plant in Ghana, (Koranteng, 1991). Sardinella stocks comprising flat sardinella (Sardinella maderensis) and round sardinella (Sardinella aurita) formed the mainstay of the marine fisheries in the entire Gulf of Guinea in the early 1970s (Hammond, 1962; Ansa-Emmim, 1973) and also constituted the bedrock of socio-economic activities for many fishers along the coast of Ghana (Kwei, 1988). The annual sardinella landings, especially S. aurita peaked in the early 1970 s at approximately 90,000 tons, but declined sharply to the point of collapse in 1973 (Fig. 15). This depletion is believed to be a result of overfishing (FRU/ORSTOM, 1976) coupled with an anomaly in the climate (Koranteng, 1991). The fishery, however, recovered in the late 1970s with increases in catches recorded between 1980 and 2004. It is however not certain what might have facilitated the recovery process of the fishery within that period, but it has been declining ever since then.

Approximately $80 \%$ of Ghanaian fishermen are artisanal and depend on the sardinella fishery for their livelihood and subsistence (Bailey, et al., 2010). Unfortunately, sardinella landings have been declining over the past ten years and nearly collapsed in 2009 as a result of overfishing associated with unsustainable and illegal methods in the face of weak governance, open fisheries access and overcapacity (FAO, 2016). Also, landings of other fish stocks in the marine fisheries of Ghana have been declining concurrently (Asiedu, Afriyie, \& Amponsah, 2018). The Ministry of Fisheries 
and Aquaculture Development (MOFAD) therefore attempts to reverse this downward trend of fish landings by closing fishing on the marine fisheries of Ghana in particular seasons to promote sustainable exploitation of the fish stocks (MOFAD, 2015). Nonetheless, the ideal duration of the closed season is unknown.

As it stands, a closed season over a period of one month has been arbitrarily proposed by MOFAD to offset the decline of the fish stocks. It is not certain if this closure period is adequate enough to achieve the intended fisheries purpose of sustainable fish stock. Seasonal fishing closures have been implemented in various locations around the world to restore depleted fish stocks (Beets \& Manuel, 2007). For instance, a 3-month closed season (December 1 - March 1) imposed on the marine fisheries in Zamboanga Peninsula of Philippines resulted in increased sardinella production as well as abundant large-sized fish (Rola, et al., 2018). Depending on the extent of depletion, fish stock recovery requires time (Pikitch, et al., 2004). Hence, Ghanaian coastal communities whose livelihood greatly depends on the fisheries are likely to face economic crisis if a long seasonal closure is implemented. It is therefore important to determine the shortest and most appropriate duration of a closed fishing season which can benefit fishers as well as sustain the fish stocks.

Life history characteristics are important inputs to population models for fisheries (Kilduff, Carmichael, \& Latour, 2009). These life-history characteristics include age at maturity, size at age and fecundity, as well as demographic rates such as growth and mortality (Wilson, et al., 2012). Studies indicate that large, slow-growing, and late-maturing fish species (e.g. rays and skates) suffer greater population declines for a specific range of mortality rates, because these attributes are associated with lower 
intrinsic rates of population growth whereas small, fast-growing and early-maturing fish species (e.g. anchovies, sardinellas) suffer relatively less population declines for the same range of mortality rates because their attributes are linked with higher intrinsic rates of population growth (Adams, 1980; Pope, et al., 2000). Thus, understanding and obtaining accurate life-history values is important for fisheries management.

Sardinellas are relatively short-lived small pelagic fish, growing isometrically and maturing around 1 year (Osei, 2015). They are gonochoristic with mostly a sex ratio of 1:1 (Gabche \& Hockey, 1995; Tsikliras \& Antonopoulou, 2006; Lawson \& Doseku, 2013; Osei, 2015). They are highly fecund and have been described as broadcast spawners, deploying the bet-hedging spawning strategy to lay many eggs in batches through a protracted period of spawning (Rochet, 2000). In Ghana, studies have shown that their spawning actvities occur throughout the year with two distinctive peaks: July - September (major season); December - March (minor season) and they are also migratory species (Koranteng, 1989).

Although seasonal closures have been shown to be a good management tool for revamping depleted fish stocks, they are unlikely to be effective if other measures like gear restrictions are not instituted during the open season (Jennings et al. 2001). Hence, this study sought to use the life history characteristics of the two sardinella fish to simulate their population dynamics under different durations for seasonal closures with and without gear restrictions to arrive at the appropriate theoretical duration of closure to ensure sustainable sardinella fishery for Ghana. 


\section{MATERIALS AND METHODS}

\section{Data collection}

Our work was conducted in Ghana of West Africa, from August 2017 to June 2018. Here, we monitored fish landings bi-monthly across the eight sites: Half-Assini, Axim, Elmina, Winneba, Botianor, Tema, Keta and Denu (Arizi, et al. in prep). To collect data simultaneously across all the sites, we had a trained field assistant at each of the eight landing sites. Each field assistant first sought consent to examine the catch of fishermen who had just returned from their fishing trips. To ascertain the sizes of sardinellas being exploited by the fishers in Ghana, fish were measured to the nearest $0.01 \mathrm{~cm}$ for total length. We then dissected each fish specimen and examined its gonad macroscopically to determine the maturity stage (mature or immature) of the fish (Tsikliras, Stergiou, \& Froese, 2013).

\section{Data analysis}

To properly capture the life history characteristics, we created life history tables (see Tables A2 \& A3 in Appendix) for the two fish using the following equations:

The two sardinella fish were assumed to grow according to the von Bertalanffy growth function generally described by this equation:

$$
L_{t}=L_{\infty}\left[1-e^{-k\left(t-t_{0}\right)}\right]
$$

$L_{t}$ is the length at time $t, L_{\infty}$ is the length at which the growth rate of the fish is zero (asymptotic length), $k$ is the growth coefficient, $t$ represents the age of the fish and $t_{0}$ is the theoretical age at which length of the fish is zero. In this work, $L_{\infty}$ of each fish was derived from Power-Wetherall method using fish samples drawn from the fish landings 
whilst $k$ and $t_{0}$ were derived from the length-frequency distribution of the fish using Bhattacharya's method (King, 1995; Sparre \& Venema, 1998).

Hence, the growth of the two fish could be described specifically by the von Bertalanffy growth function as:

$$
\begin{gathered}
L_{t, \text { flat sardinella }}=32.21\left[1-e^{-0.576(a-(-0.49))}\right] \\
L_{t, \text { round sardinella }}=30.17\left[1-e^{-0.582(a-(-0.31))}\right]
\end{gathered}
$$

In this paper, the age of the fish (a) was calculated based on the von Bertalanffy growth function as:

$$
a=-\frac{1}{k} L N\left[1-\frac{L_{t}}{L_{\infty}}\right]+t_{0}
$$

The ratio of total mortality $(Z)$ to growth coefficient $(K), Z / k$ was derived from the slope of Power-Wetherall regression method. The total mortality $(Z)$ of each population was calculated from this ratio. The natural mortality, which integrates all the ages of each fish population was estimated from Hewitt and Hoening's (2005) longevity-based equation:

$$
M=\frac{4.22}{a_{\max }}
$$

Where $M$ is an instantaneous natural mortality of the fish population and $a_{\max }$ is the maximum age observed within the population. The instantaneous fishing mortality that each sardinella population experiences was determined from this equation:

$$
F=Z-M
$$

Where $F$ is instantaneous fishing mortality of the fish population, $Z$ and $M$ have already been defined. 
According to Chen and Watanabe (1989), natural mortality in fish populations follows a bathtub curve (U-shaped curve) when it is plotted against age implying that natural mortality of fish at a particular age is somewhat inversely proportional its growth:

$$
\begin{aligned}
& M(t)=\left\{\begin{array}{c}
\frac{k}{1-e^{-k\left(t-t_{0}\right)}}, t \leq t_{m} \\
\frac{k}{a_{0}+a_{1}\left(t-t_{m}\right)+a_{2}\left(t-t_{m}\right)^{2}}, t \geq t_{m}
\end{array}\right. \\
& \text { Where }\left\{\begin{array}{c}
a_{0}=1-e^{-k\left(t_{m}-t_{0}\right)} \\
a_{1}=k e^{-k\left(t_{m}-t_{0}\right)} \\
a_{2}=-\frac{1}{2} k^{2} e^{-k\left(t_{m}-t_{0}\right)}
\end{array}\right. \\
& \text { And } t_{m}=-\frac{1}{k} L N\left[1-e^{k\left(t_{0}\right)}\right]+t_{0}
\end{aligned}
$$

Where $k$ is the constant of proportionality which also represents the growth coefficient of the fish population, $t$ is the age of the fish, $t_{0}$ is the theoretical age at length zero and $t_{m}$ is the age at the end of reproductive span; $k$ and $t_{0}$ are parameters of the von Bertalanffy growth function.

In principle, natural mortality does not only depend on the growth of the fish but has some degree of dependence on prevailing environmental conditions and fishinginduced disturbances, particularly within aquatic systems where fishing occurs. In this work, Chen and Watanabe's equation was revised to indirectly account for such environmental factors where natural mortality of fish at a particular age, $a$ was assumed to be directly proportional to the natural mortality of the sardinella population $(M)$ as a fraction of the total mortality $(Z)$ experienced by the entire fish population but inversely 
proportional to the growth of individual fish. Hence, the natural mortality at age, $M_{a}$ was calculated from this equation:

$$
M_{a}=\left\{\begin{array}{c}
k \frac{\frac{M}{Z}}{1-e^{-k(t-t 0)}}, t \leq t_{m} \\
k \frac{\frac{M}{Z}}{a_{0}+a_{1}\left(t-t_{m}\right)+a_{2}\left(t-t_{m}\right)^{2}}, t \geq t_{m}
\end{array}\right.
$$

Where $k, t, t_{0}, t_{m}, M$ and $Z$ have all been explained.

During the fieldwork, six main fishing gears were encountered in Ghana's sardinella fishery, namely ali, poli, watsa, poli-watsa, set net and beach seine (Arizi, et al., in prep). Hence, fishing mortality of individual fish at age $a$ of each species, $s$ for each gear, $g\left(F_{a(s, g)}\right)$ was calculated as:

$$
F_{a(s, g)}=\frac{F}{C} C_{a(s, g)}
$$

Where $F$ is the annual fishing mortality each fish species experiences, $C$ is the total fish catch of each species in the samples and $C_{a(s, g)}$ is the catch of each fish species, $S$ at age, $a$ in the samples.

The total fishing mortality of fish at age $a, F_{a}$ belonging to a particular fish population was determined from this sum:

$$
F_{a}=\sum_{g=1}^{6} F_{a(s, g)}
$$

Annual survival rate of the fish at age $a\left(S_{a}\right)$ was computed from this relation

$$
S_{a}=e^{-\left[\left(F_{a}+M_{a}\right) * t\right]}
$$

Where $t$ is the year which is equal to 1 in this case, $F_{a}$ and $M_{a}$ have all been defined already.

Proportion mature at age $\left(P_{a}\right)$ was calculated from this logistic function: 


$$
P_{a}=\frac{1}{1+e^{-\beta\left(a-a_{m a t}\right)}}
$$

Where $a_{m a t}$ is the age at first sexual maturity representing the age at which $50 \%$ of the fish was mature whilst $\beta$ is the slope of the logit regression curve fitted to the proportion mature by fish age. The $a_{m a t}$ was determined from this ratio:

$$
a_{m a t}=\frac{\alpha}{\beta}
$$

$\alpha$ is the intercept of the linearly transformed logit regression function fitted to the proportion mature by fish age and $\beta$ has already been defined.

The fecundity $(f)$ at age $(a)$ was given by:

$$
f_{a}=c\left[L_{\infty}\left(1-e^{-k\left(t-t_{0}\right)}\right)\right]^{b}
$$

Where $f_{a}$ is fecundity at age $a, c$ and $b$ as constants derived from the age-fecundity power regression function with $t_{0}$ and $k$ generated from the von Bertalanffy growth function.

Using age-fecundity data on the two sardinella species from Osei's work (2015), the fecundity of each fish was specifically calculated from these equations:

$$
\begin{aligned}
& f_{\text {flat sardinella }}=49.36\left[L_{\infty}\left(1-e^{-k\left(t-t_{0}\right)}\right)\right]^{1.80} \\
& f_{\text {round sardinella }}=0.282\left[L_{\infty}\left(1-e^{-k\left(t-t_{0}\right)}\right)\right]^{3.58}
\end{aligned}
$$

The mean population abundance of the terminal age of the fish $\left(N_{A}\right)$ in each fish population was calculated from this relation:

$$
N A=\left[\frac{z_{a}}{F_{a}\left(1-e^{\left.-z_{a}\right)}\right.}\right] C_{A}
$$

Where $C_{A}$ is the catch of the terminal age of the fish; $Z_{a}$, and $F_{a}$ have been already defined. 
However, the population abundance of each age at time $t$ below the terminal stage was back-calculated as

$$
N_{a(t)}=\frac{N_{(a+1),(t+1)}}{e^{-Z_{a}(t+1)}}
$$

Where $Z_{a}$ is the totality mortality at age $a ; Z_{a}$ was simply computed from this equation:

$$
Z_{a}=F_{a}+M_{a}
$$

The survival probability of the eggs per each species, $S_{e}$ was determined using this equation:

$$
S_{e}=\frac{N_{(0),(t+1)}}{\sum_{a=0}^{A} N_{a,(t)} P_{a} f_{a}}
$$

Where $N_{(0),(t+1)}$ is the abundance of fish at age 0 at time $t+1, N_{a},(t)$ is the abundance of fish at age $a$ at time $t, f_{a}$ and $P_{a}$ have already been defined.

The use of life stages other than age in vertebrate populations can increase the accuracy of population projections and also provide new insights into the evolution of life history characteristics (Sauer \& Slade, 1986). Lefkovitch (1965) has generalized Leslie's (1945) matrix model of age-structured population growth to include stagetransition matrices. We therefore used a combination of Lefkovitch and Leslie models (Tables A4 \& A5) to study and understand the population dynamics of the fish under different periods of seasonal closures with and without gear restrictions so as to arrive at the right combination of management strategies for enhancing the growth of the fish in the coastal waters of Ghana. Based on the assumption that the population parameters of each sardinella fish remain constant over time, the population matrix of the Lefkovitch-Leslie matrix model which is generally written as (22) was used in the analysis:

$$
N_{t+1}=\boldsymbol{M} N_{t} \quad(\text { Quinn II \& Deriso, 1999) }
$$


Where $N_{t}$ is the population vector of female abundance in year $t, \boldsymbol{M}$ is the projection matrix which accommodates all the components of biological and fishery production (reproduction, individual growth, natural mortality and fishing mortality). In this model, only the females were considered because it is their female progeny that propagates the fish species. Notably, a sex ratio of almost 1:1 exhibited by each sardinella species indicates that the fertilities of the females are not constrained by the number of their male counterparts (see Table A1 in Appendix).

From equation (22), when the fishery is closed within a period of time, $\frac{x}{12}$ where $x$ is the duration of closed season expressed in months, then the population abundance at the end of the closed season $t+\frac{x}{12}$ is given by

$$
N_{\left(\mathrm{t}+\frac{x}{12}\right)}=\left(\boldsymbol{M}_{\frac{x}{\mathbf{1 2}}}\right) N_{t}
$$

Where $N_{\left(\mathrm{t}+\frac{x}{12}\right)}$ is a vector of the population abundance of fish at the end of the closed season $t+\frac{x}{12}, M_{\frac{x}{12}}$ is the projection matrix for the closed season (see Table A4 in the Appendix section) and $N_{t}$ is a vector of initial population sizes of the various age, $a$ at time, $t$.

The population abundance of fish at age 0 depends on the reproduction of all the ages. Hence, the first row of $\boldsymbol{M}_{\frac{x}{\mathbf{1 2}}}$ accommodated the fertilities of the fish per the closed

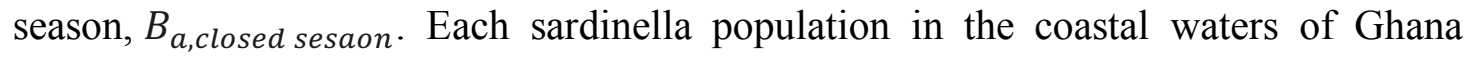
spawns twice a year with the major breeding occurring within July - September whereas the minor mostly spans over December - February (Osei, 2015). Assuming 75\% of the spawning representing the major season occurs within the closed season, the fertility of fish at age $a$ was determined from this equation: 


$$
B_{a, \text { closed sesaon }}=0.75 f_{a} P_{a} S_{e}
$$

Where $f_{a}$ is the fecundity at age $a, P_{a}$ is the proportion mature of fish at age $a, S_{e}$ is the survival rate of the eggs.

The survival probabilities of the fish within the seasonal closure period were calculated from equation (12). A fishing ban imposed on the sardinella fishery implies that $F_{a}=0$. Considering the seasonal closure on a monthly basis where the duration of closed season is represented by $x$, equation (12) becomes:

$$
S_{a, \text { closed season }}=e^{-\left[\left(M_{a}\right) * \frac{x}{12}\right]}
$$

Depending on the ages of the fish, these survival probabilities were set up subdiagonally in $\boldsymbol{M}_{\frac{x}{12}}$.

Fishing activities presumably succeed the closed season whenever the fishing moratorium is lifted. Here, the population abundance at the end of the closed season, $N_{\left(\mathrm{t}+\frac{x}{12}\right)}$ becomes the population vector containing the abundance of the various ages of the fish at the beginning of the fishing season. Hence, if fishing continues until the end of the year, then the fish population abundance at the end of the year $t+1, N_{\mathrm{t}+1}$ could be written as:

$$
N_{\mathrm{t}+1}=\left(\boldsymbol{M}_{\frac{12-x}{12}}\right) N_{\left(\mathrm{t}+\frac{\mathrm{x}}{12}\right)}
$$

Where $\left(\boldsymbol{M}_{\frac{12-x}{12}}\right)$ is the projection matrix for the fish population per the fishing season (see Table A5 in the Appendix section) and $N_{\left(\mathrm{t}+\frac{\mathrm{x}}{12}\right)}$ constitutes the population vector for the beginning of the fishing season.

Assuming $25 \%$ of the spawning representing the minor season occurs during the 
fishing season, the fertility of proportion of fish at age $a$ per the fishing season was determined from this equation:

$$
B_{a, \text { fishing sesaon }}=0.25 f_{a} P_{a} S_{e}
$$

In the fishing season scenario, the subdiagonal survival probabilities were shifted one step forward in $M_{\frac{12-x}{12}}$ to account for the time covered by the closure period. Thus, the survival probabilities are accommodated in the main diagonal (see Table A5 in the Appendix).

Nonetheless, the survival rate of the fish within the fishing season was calculated from this equation:

$$
S_{a, \text { fishing season }}=e^{-\left[\left(F_{a}+M_{a}\right) * \frac{12-x}{12}\right]}
$$

When equation (23) is substituted into equation (26), the fish population abundance at the end of the year $t+1, N_{\mathrm{t}+1}$ could simply be calculated as:

$$
N_{\mathrm{t}+1}=\left(\boldsymbol{M}_{\frac{12-x}{12}}\right)\left(\boldsymbol{M}_{\frac{x}{12}}\right)\left(N_{t}\right)
$$

Where $\left(\boldsymbol{M}_{\frac{x}{12}}\right)$ represents the projection matrix for the fish per the closed season and $\left(\boldsymbol{M}_{\frac{12-x}{12}}\right)$ stands for the projection matrix for the fish per the fishing season. It must be noted that the positions of the matrices in equation (29) must not be changed in the course of the substitution.

Using the rules of matrix algebra to calculate the changes in abundance of fish, the dominant eigenvalue $(\lambda)$ of the product of the two matrices was extracted. This dominant eigenvalue $(\lambda)$ represents the population growth rate of the fish species whose biological and fishery production components were set up in the projection matrices.

Assuming that each sardinella population is density-dependent, the growth of 
each population was fitted by logistic growth function given to project the fish abundance over time as:

$$
N_{t+1}=\frac{K}{1+\left[\frac{K-N_{t}}{N_{t}}\right] \lambda^{-t}}
$$

Where $N_{t+1}$ is the projected fish population abundance over time $t, K$ is the carrying capacity of the fish population, $N_{t}$ is the initial fish population. The carrying capacity $(K)$ of each fish was derived from the surplus production model fitted to catch-effort data which were obtained from the Fisheries Commission of Ghana.

Initial population size, $N_{t}$ of each fish species was calculated from the sum of the average population abundance of all the age groups of the fish using this equation:

$$
N_{t}=\sum_{a=0}^{A} N_{a, t}
$$

Where $N_{a, t}$ is the population abundance at age $a$ at time $t, A$ represents the oldest fish in the population and 0 is the age of the youngest fish among all the age groups.

To account for seasonal closure with gear restrictions which is more of mesh size regulation, the fishing mortalities of the fish at age 0 were set zero.

Sensitivity and elasticity analyses were conducted using the matrices to determine the effects of changes in the life history attributes (e.g. fecundity and survival rates) on the population growth rate $(\lambda)$ of each fish species.

\section{RESULTS}

The growth rates (dominant eigenvalues) of the $S$. maderensis under the seasonal closure with and without gear restrictions in the major breeding season were quite 
variable, ranging from $0.98-1.56 \mathrm{yr}^{-1}$ with the lowest growth rate estimated at $0.98 \mathrm{y}^{-1}$ for the status quo (absence of closed season) as shown in Fig. 16. Under the closed season without any gear restrictions, the growth rate increased from 0.99 to $1.56 \mathrm{yr}^{-1}$ according to an increasing order of the closure period indicating that the longer the period of fishing closure, the higher the growth rate of the fish. A closure period less than 2 months without any restrictions resulted in a decline of the $S$. maderensis fish but the population became stable during a 2-month closure period and grew negligibly at a 3-month closure period. The $S$. maderensis population, however, grew relatively faster at a rate of $1.1 \mathrm{yr}^{-1}$ when a 3-month fishing closure or more was theoretically implemented. Under the closed season with gear restrictions, the S. maderensis population grew relatively faster when a 1-month closure or beyond was theoretically simulated.

The growth rates of the $S$. aurita population under the seasonal closure with and without gear restrictions in the major breeding season ranged from $0.89-2.59 \mathrm{yr}^{-1}$; the lowest growth rate was estimated for the status quo (Fig. 17). Similarly, the round sardinella population declined when a closed season less than 1 month without any gear restrictions was theoretically implemented but became stable at a 2-month closure period and grew relatively when a 3-month closure or beyond was implemented. Under 1-month closure and beyond in conjunction with gear restrictions, the $S$. aurita population, however, grew rapidly. When a 1-month closure with gear restrictions was simulated, the lowest growth rate for enhancing the growth of the $S$. aurita in the coastal waters of Ghana was estimated at $1.71 \mathrm{yr}^{-1}$. 
In general, the sensitivities and elasticities for both fertility and survival rates of the two fish species decreased with an increasing age for all the closure scenarios (Figures A18 - A63) suggesting that the population growth rates of both S. maderensis and $S$. aurita populations were most sensitive to the survival rates of the juveniles.

\section{DISCUSSION}

To make an output of stock assessment more reliable to inform management decisions, the underlying input parameters must be estimated accurately and precisely based on unbiased sample collections and robust estimation techniques (Jennings, Reynolds, \& Mills, 1998). The life history characteristics of the two sardinellas we determined using a large sample size (14, 088 individuals) in this study were comparable to what other researchers have already reported (e.g. Quaatey \& Maravelias, 1999; Osei, 2015). Implementation of a closed season in the breeding season is often effective for species which aggregate to breed (Arendse, Govender, \& Branch, 2007). Sardinellas are noted for their schooling behaviour; in Ghana, this behaviour of the fish is more pronounced in the major breeding (Kwei \& Ofori-Adu, 2005), making the fish highly vulnerable to exploitation (Koranteng, 1991). This feature formed the basis of our focus on testing the effectiveness of closed season in breeding seasons on the population dynamics of sardinellas in Ghana.

Our results suggest that the population size of the sardinellas in the coastal waters of Ghana will continue to dwindle and eventually collapse within 15 - 20 years under the management status quo. This finding agrees with Lazar, et al. (2018) who have also predicted that the biomass of the small pelagic stocks including sardinella is going to crash within 20 years if the present conditions are allowed to prevail. This 
decline is largely due to high current exploitation rate (Lazar, et al., 2016) engendered by the high number of fishing fleets in the fishing industry of Ghana (Dovlo, Amador, \& Nkrumah, 2016). Growth overfishing and recruitment overfishing have been confirmed in the small pelagic stocks of Ghana (Lazar, et al., 2016). The high number of small-sized individuals observed in the landings during the sampling period as evidenced in the fishing mortalities (Table A2 \& A3) further confirms the growth overfishing in the sardinella fishery. The incessant decline in the population size of the fish is an indication that the rate of removal of fish through fishing is relatively higher than the rate of recruitment of young individuals through reproduction into the population.

We also show that a closed season in the major breeding season lasting for less than 1 month without any gear restrictions has no positive effects on the population growth of the sardinellas. The primary goal of enacting fisheries laws is to conserve fish stocks and their environment. Hence, it is ecologically irrational to implement fisheries policies to safeguard certain fish species and then ignore other related fish species (Pikitch, et al., 2004). If the sardinella populations are not favored by a shorter duration of seasonal closure (less than 1 month), then any fisheries management policy that considers a shorter duration of closure might be illogical to execute in Ghana. Unfished fish populations grow faster than fished stocks. Similarly, less fished stocks grow faster than highly fished stocks. When a closed season is imposed on a depleted fishery for a remarkable period of time, the fish stock is likely to recover quickly, implying that the longer the period of closed season, the faster the growth of fish population. In Ghana, many fishermen highly depend on the sardinella fishery for their livelihoods. By 
implication, a longer fishing closure is likely to inflict economic crisis on the fishermen. The scenario related to the seasonal closure without any gear restrictions which suggests that a closure duration of 3 months or more is the ideal duration for sustaining the sardinella fishery might not be an option to consider given that most fishermen rely the fishery for food and income security.

The population growth rates of $S$. maderensis and $S$. aurita populations which were very sensitive to the survival rates of the juveniles suggest that increase in the survival rates of the juveniles would cause an increase in the population growth rate of the fish. Hence, fisheries management should focus on increasing the survival rates of the juveniles. This therefore calls for the need to explore other management options such as gear restrictions. The high mortalities observed in immature fish individuals (age 0) imply that majority of the fish are caught before their first spawning period is due. Thus, even if the closure is prolonged, if many juveniles, which should grow into the adult stage to contribute reproductively to the population, are constantly removed from the stock, the closure would be fruitless. It is therefore important to prevent a high proportion of immature fish from being exploited.

To test whether gear restrictions or mesh size regulation could serve as a catalyst for seasonal closure to enhance the population growth of the fish, we eliminated the fishing mortalities of the juveniles (individuals at age 0 ) from the analysis by setting that to zero. Our findings showed that a one-month closed season in the major breeding season with gear restrictions, where fish of age 1 and above are mostly selected by the gears other than fish of age 0 , could revamp the sardinella fishery within a period of 5 - 
10 years. These findings reinforce the need to take gear restrictions in the Ghanaian fishery very seriously.

Transition projection matrices covering seasons provide an accurate model of the changes in the population sizes of vertebrates over time (Sauer \& Slade, 1986). Our transition matrices for the status quo scenario, which provide results reflecting the declining nature of the sardinella stocks, seem to suggest that our model which captures the seasonal spawning activities of the two sardinella species is adequate for describing the population dynamics of the fish. Ghana shares maritime boundaries with Ivory Coast and Togo and these countries share the same stocks of sardinella (Brainerd, 1991). Hence, the assumption that emigration rates and immigration rates of each population are equal might have some consequences on the outcome of these results. Also, the fecundity data were not from our field data but were derived from Osei's (2015) work. Creation of marine protected areas (MPAs) in the coastal waters of Ghana might be another potential management strategy but the migratory nature and weak governance are barriers to success and implementation. Fishing mortalities of the fish in this study were computed based on the catch of the fish at age in the fishing gears and so these mortalities do not necessarily represent age-based fishing mortalities of the fish. Some of the new methods presented in this work are liable to further review.

\section{CONCLUSIONS}

To conclude, the life history characteristics of the fish which were derived from relatively large sample size do not differ remarkably from what is in the literature. The population size of sardinellas in the coastal waters of Ghana is ceaselessly dwindling under the present management conditions (status quo) as a result of high exploitation 
rate of fish with greater impact on immature fish. A duration of seasonal closure less than 3 months with any gear restrictions is not even enough to revamp the sardinella fishery of Ghana as a result of high fishing pressure on the juvenile stage of the fish (indicator of growth overfishing). However, a one-month seasonal closure with gear restrictions which encourages escapement of juveniles in the fishery is an ideal management option to consider for sustaining the sardinella fishery of Ghana.

\section{ACKNOWLEDGEMENT}

The authors are grateful to USAID for funding this study through the Ghana Sustainable Fisheries Management Project (SFMP) implemented by the Coastal Resources Center (CRC). The logistical support provided by the Department of Fisheries and Aquatic Sciences (University of Cape Coast) during the fieldwork is highly appreciated. 


\section{REFERENCES}

Akyeampong, S., Amador, K., \& Nkrumah, B. (2013). Report on the 2013 Ghana marine canoe frame survey. Ministry of Fisheries and Aquaculture Development, Fisheries Commission, Fisheries Scientific Survey Division. Accra: Republic of Ghana.

Ansa-Emmim, M. (1973). Pelagic fishes. In The Ghana fishing industry (pp. 42-46). Tema.

Arendse, C. J., Govender, A., \& Branch, G. (2007). Are closed fishing seasons an effective means of increasing reproductive output? A per-recruit simulation using the limpet Cymbula granatina as a case history. Fisheries Research.

Asiedu, B., Afriyie, G., \& Amponsah, S. (2018, August 29th). Overview of marine stock enhancement, restocking and sea ranching in Ghana. Retrieved July 2019, from Public Management and Administration: http://dx.doi.org/10.5772/intechopen.79454

Bailey, M., Quaatey, S., Armah, A. K., Jacquet, J., Khan, A., Alder, J., \& Sumailia, R. (2010). Meeting socioeconomic objectives in Ghana's sardinella fishery. In D. Nanang, \& T. K. Nunifu, Natural Resources in Ghana. Nova Science Publishers, Inc.

Beets, J., \& Manuel, M. (2007). Temporal and seasonal closures used in fisheries management:a review with application to Hawaii. Retrieved from http://dnr.hawaii.gov/coralreefs/files/2015/02/BeetsTempClosuresRpt08.pdf

Brainerd, T. R. (1991). The sardinella fishery off the coast of West Africa: the case of a common property resource. Paper presented at the Second Annual Conference 
of the International Association for the Study of Common Property (IASCP), University of Manitoba, Winnipeg, Canada.

Chen, S., \& Watanabe, S. (1989). Age Dependence of Natural Mortality Coefficient in Fish Population Dynamics. Nippon Suisan Gakkaishi(55), 205-208.

Dovlo, E., Amador, K., \& \& Nkrumah, B. (2016). Report on the 2016 Ghana marine canoe frame survey. Accra: Republic of Ghana.

FAO. (1989). Rapport de la consultation technique sur les petites espèces pèlagiques de la division statistique Golfe de Guinèe ouest. FAO. Abidjan: FAO.

FAO. (2016). FAO regional capture fisheries statistics; CECAF capture production $\left.\begin{array}{lllll}\text { quantity } & (1970 \quad & - & 2014\end{array}\right) . \quad$ Retrieved $\quad$ from http://www.fao.org/fishery/statistics/software/fishstatj/en

FRU/ORSTOM. (1976). Rappon du groupe de travail Sur la sardinelle (S. aurira) des côtes ivoiro-ghanéennes, Abidjan 28 Juin-2 Juillet, 1976.

Gabche, C., \& Hockey, U. (1995). Growth, mortality and reproduction of Sardinella maderensis (Lowe, 1841) in the artisanal fisheries off Kribi, Cameroon. Fisheries Research, 4(2), 331-344.

Hammond, D. (1962). The herring season. In Fisheries Research Report Vol 1 (1) (pp. 11-14). Accra: Fisheries Inspectorate Unit.

Hewitt, D., \& Hoenig, J. (2005). Comparison of two approaches for estimating natural mortality based on longevity. Fishery Bulletin(103), 433-437.

Jennings, S., Kaiser, J. M., \& Reynolds, D. J. (2001). Marine Fisheries Ecology. Oxford: Blackwell Science Ltd. 
Jennings, S., Reynolds, J., \& Mills, S. (1998). Life history correlates of responses to fisheries exploitation. Proceedings of Royal Society of London, series B: Biological Sciences, 1393(265), 333 - 339.

Kilduff, P., Carmichael, J., \& Latour, R. (2009). Guide to Fisheries Science and stock assessments. Arlington: Atlantic States Marine Fisheries Commission.

King, M. (1995). Fisheries biology, assessment and management. London: Blackwell Science Ltd.

Koranteng, K. A. (1989). The sardinella fishery in Ghana, the past, recent development and the years ahead. Tema: Fisheries Department Research and Utilization Branch.

Koranteng, K. A. (1991). Some aspects of the sardinella fishery in Ghana. In P. Cury, \& C. Roy, eds.) Pêcheries Ouest-Africaines Variabilité, Instabilité et Changement. Paris, France: Editions de I'ORSTOM.

Kwei, E. (1988). Animals with reference to fisheries. 29th Anniversary Lectures. Accra: Ghana Academy of Arts and Sciences.

Kwei, E., \& Ofori-Adu, D. (2005). Fishes in the coastal waters of Ghana. Tema, Ghana: Ronna Publishers.

Lawson, E., \& Doseku, P. (2013). Aspects of Biology in Round Sardinella, Sardinella aurita (Valenciennes, 1847) from Majidun Creek, Lagos, Nigeria. World Journal of Fish and Marine Sciences, 5(5), 575-581.

Lazar, N., Yankson, K., Blay, J., Ofori-Danson, P., Markwei, P., Agbogah, K., . . . Bilisini, W. B. (2016). Rebuilding Depleted Small Pelagic Stocks in Ghana. A Closed Fishing Season Proposal to the Ministry of Fisheries and Aquaculture 
Development. University of Rhode Island, Coastal Resources Center, Graduate School of Oceanography. Narragansett: University of Rhode Island.

Lazar, N., Yankson, K., Blay, J., Ofori-Danson, P., Markwei, P., Agbogah, K., . . . Bilisini, W. B. (2018). Status of the small pelagic stocks in Ghana and recommendations to achieve sustainable fishing 2017. University of Rhode Island, Coastal Resources Center, Graduate School of Oceanography. Narragansett: University of Rhode Island.

Lefkovitch, L. (1965). The study of population growth in organisms grouped by stages. Biometrics(21), 1-18.

Leslie, P. (1945). The use of matrices in certain population mathematics. Biometrika(33), 183-212.

MOFAD. (2015). Fisheries Management Plan. Accra: Ministry of Fisheries and Aquaculture Development, Goverment of Ghana.

Osei, I. (2015). Aspects of the biology of Sardinella aurita and Sardinella maderensis (Clupeidae) in the coastal waters of Central Region, Ghana. University of Cape Coast. Cape Coast: University of Cape Coast, Ghana.

Pikitch, E. K., Santora, C., Babcock, E. A., Bakun, A., Bonfil, R., Conover, D. O., . . Sainsbury, K. (2004). Ecosystem-based fishery management. Science(305), 346-347.

Quaatey, S., \& Maravelias, C. (1999). Maturity and spawning pattern of Sardinella aurita in relation to water temperature and zooplankton abundance off Ghana, West Africa. Journal of Apllied Ichthyology(15), 63-69. 
Quinn II, T., \& Deriso, R. B. (1999). Quantitative fish dynamics. Oxford, USA: Oxford University Press.

Rochet, M. (2000). A comparative approach to life-history strategies and tactics among four orders of teleost fish. ICES Journal of Marine Science(57), 228 - 239.

Rola, A., Narvaez, T., Naguit, M., Elazegui, D., Brillo, B., Paunlagui, M., .. . Cervantes, C. (2018). Impact of the closedfishing season policy for sardines in Zamboanga Peninsula, Philippines. Marine Policy(87), 40-50.

Sauer, J., \& Slade, N. (1986). Size-dependent population dynamics of Microtus ochrogaster. The American Naturalist(127), 902-908.

Sparre, P., \& Venema, S. (1998). Introduction to tropical fish stock assessment. FAO. Rome: FAO.

Tsikliras, A., \& Antonopoulou, E. (2006). Reproductive biology of round sardinella (Sardinella aurita) in the north-eastern Mediterranean. Scientia Marina, 2(70), 281- 290 .

Tsikliras, A., Stergiou, K., \& Froese, R. (2013). Editorial note on reproductive biology of fishes. Acta Ichthyologica et Piscatoria, 1(43), 1-5.

Wilson, J. R., Kay, M. C., Colgate, J., Qi, R., \& Lenihan, H. S. (2012). Small-scale variation in population dynamics and fishermen response in a coastal marine fishery. PLOS ONE, 12(7), 1-11. 


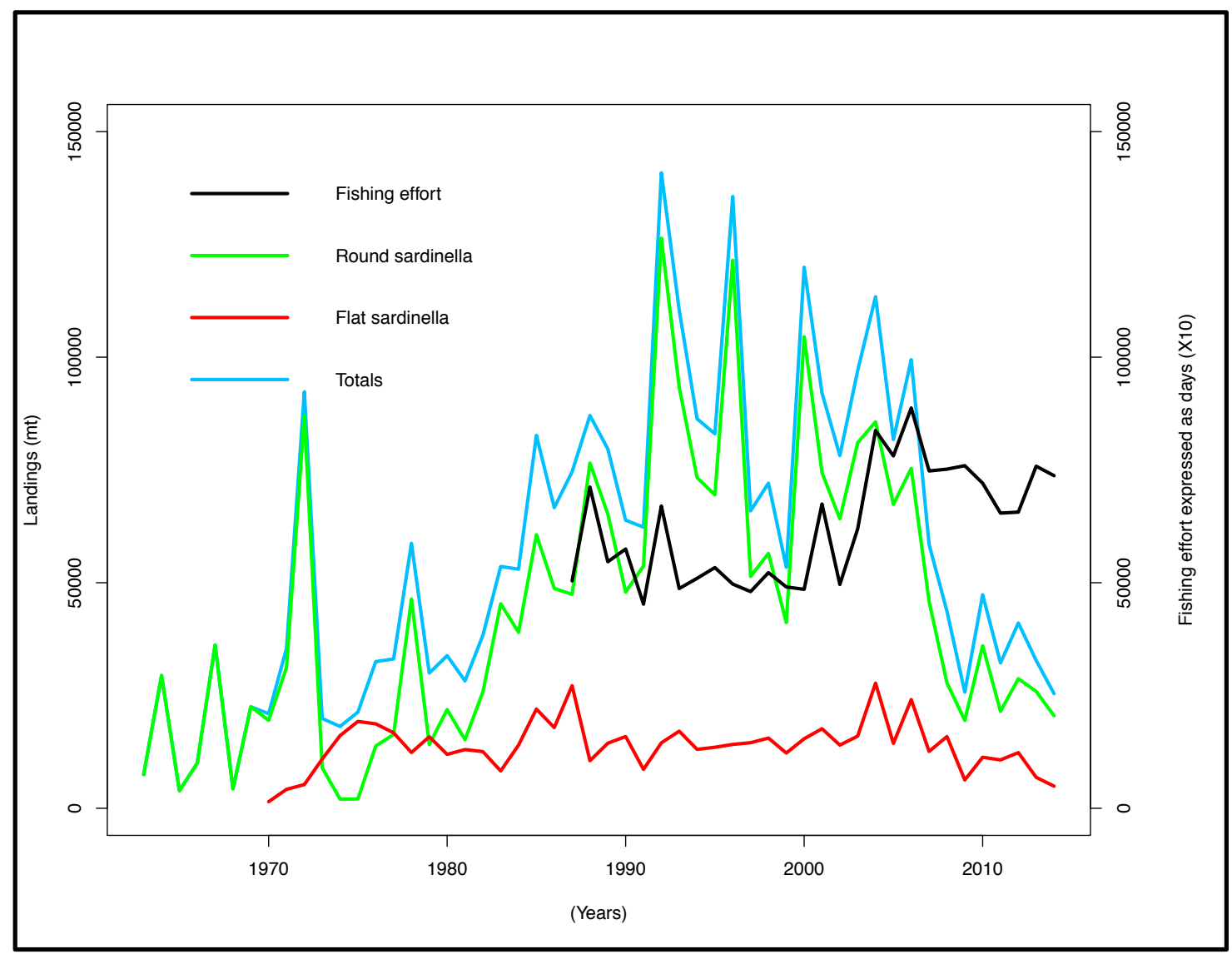

Fig. 15. Fishing effort and landings of sardinella fish in Ghana (FAO, 1989; 2016) 


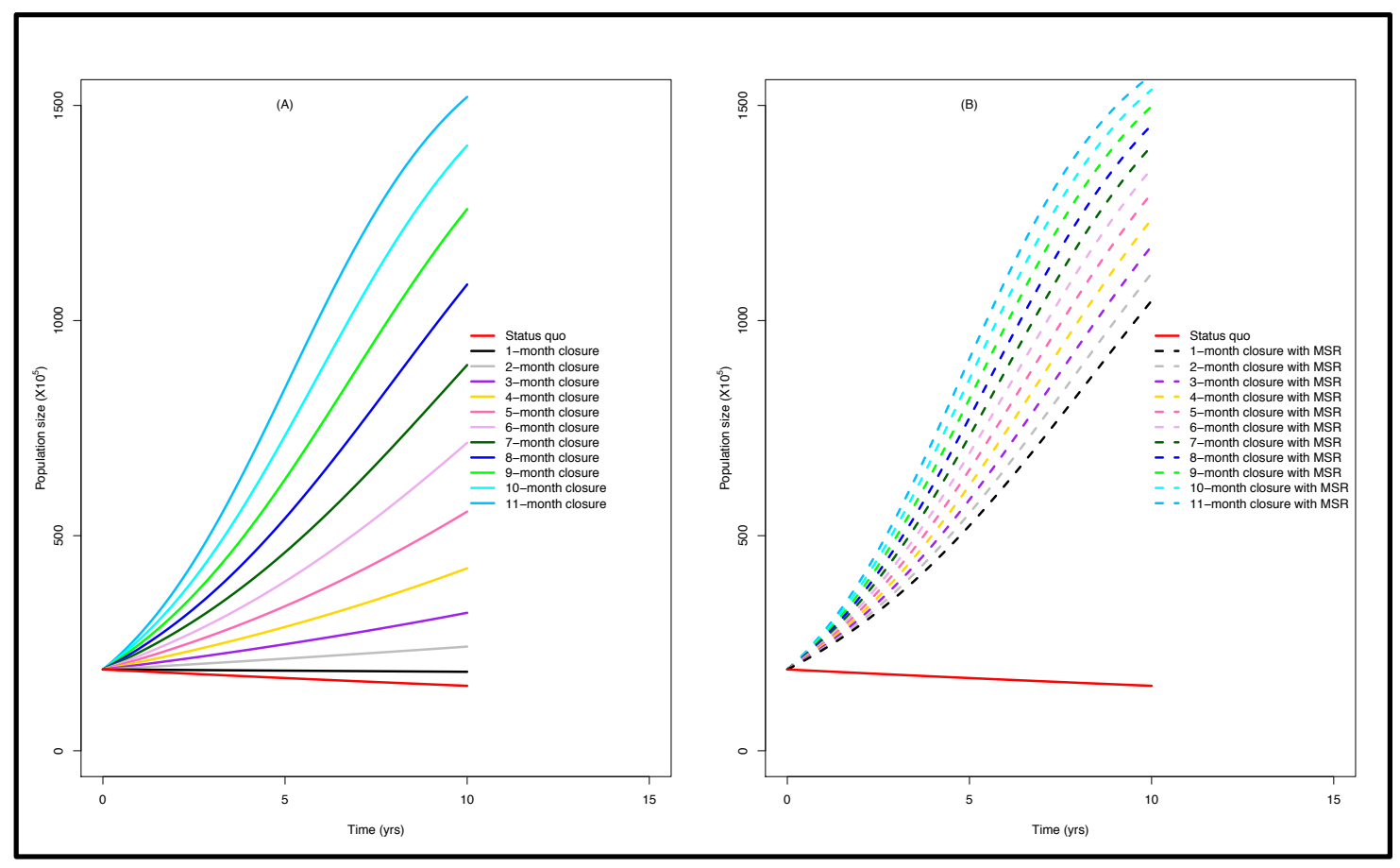

Fig. 16. Population size of $S$. maderensis projected over a 10-year period under: (A) closed season without any gear restrictions scenario; (B) closed season with gear restrictions scenario. MSR stands for mesh size regulation expressed as exclusion from the analysis the fishing mortalities of fish at age 0 


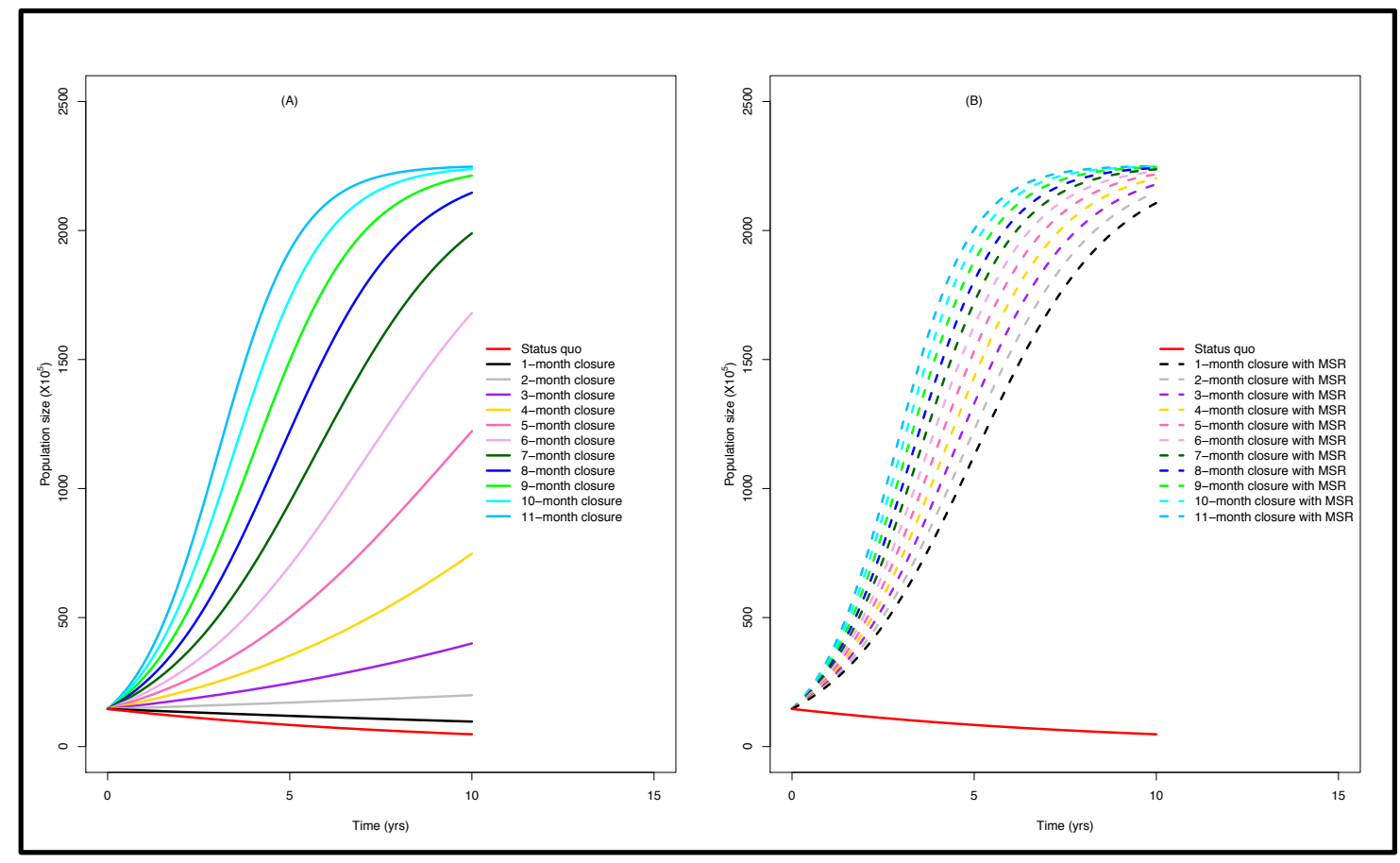

Fig. 17. Population size of $S$. aurita projected over a 10-year period under: (A) closed season without any gear restrictions scenario; (B) closed season with gear restrictions scenario. MSR stands for mesh size regulation expressed as exclusion from the analysis the fishing mortalities of fish at age 0 


\section{APPENDIX:}

Table A1. The growth, mortality and reproductive parameters of flat sardinella and round sardinella in the coastal waters of Ghana

\begin{tabular}{|c|c|c|}
\hline \multirow[t]{2}{*}{ Parameter } & \multicolumn{2}{|c|}{ Species } \\
\hline & Flat sardinella & Round sardinella \\
\hline Asymptotic length, $\mathrm{L}_{\infty}(\mathrm{cm})$ & 32.21 & 30.71 \\
\hline Growth coefficient, $\mathrm{k}\left(\mathrm{yr}^{-1}\right)$ & 0.576 & 0.582 \\
\hline Theoretical age, $\mathrm{t}_{0}(\mathrm{yr})$ & -0.49 & -0.31 \\
\hline Ratio of total mortality $(\mathrm{Z})$ to & 3.167 & 7.33 \\
\hline \multicolumn{3}{|l|}{ growth coefficient $(\mathrm{k}), \mathrm{Z} / \mathrm{k}$} \\
\hline Total mortality, $\mathrm{Z}\left(\mathrm{yr}^{-1}\right)$ & 1.824 & 4.27 \\
\hline Natural mortality, $\mathrm{M}\left(\mathrm{yr}^{-1}\right)$ & 0.688 & 1.00 \\
\hline Fishing mortality, $\mathrm{F}\left(\mathrm{yr}^{-1}\right)$ & 1.136 & 3.27 \\
\hline Maximum observed length, $\mathrm{L}_{\max }$ & 31.5 & 28.0 \\
\hline \multicolumn{3}{|l|}{$(\mathrm{cm})$} \\
\hline Maximum observed age, $\mathrm{t}_{\max }(\mathrm{yr})$ & 6.1 & 4.2 \\
\hline Sex ratio $(M: F)$ & $1.00: 1.16$ & $1.00: 1.05$ \\
\hline
\end{tabular}


Table A2. Life history table of flat sardinella in the coastal waters of Ghana

\begin{tabular}{|c|c|c|c|c|c|c|}
\hline $\begin{array}{c}\text { Age, a } \\
\text { (yr) }\end{array}$ & $\begin{array}{c}\text { Natural } \\
\text { mortality, } \\
\mathbf{M}_{\mathbf{a}} \\
\left(\mathbf{y}^{-1}\right)\end{array}$ & $\begin{array}{c}\text { Fishing } \\
\text { mortality, } \\
F_{\mathrm{a}} \\
\left(\mathbf{y}^{-1}\right)\end{array}$ & $\begin{array}{l}\text { Survival } \\
\text { rate, } S_{a} \\
\left(y^{-1}\right)\end{array}$ & $\begin{array}{l}\text { Proportion } \\
\text { mature, } \mathrm{P}_{\mathrm{a}}\end{array}$ & $\begin{array}{c}\text { Fecundity, } \\
\mathbf{f}_{\mathbf{a}}\end{array}$ & $\begin{array}{c}\text { Number } \\
\text { of } \\
\text { females, } \\
N_{a} \text { in } \\
2018\end{array}$ \\
\hline 0 & 0.8831 & 0.7203 & 0.2012 & 0.000 & 2047 & 126876 \\
\hline 1 & 0.3769 & 0.3655 & 0.4759 & 0.752 & 9476 & 25531 \\
\hline 2 & 0.2851 & 0.0403 & 0.7222 & 1.00 & 15665 & 12151 \\
\hline 3 & 0.2531 & 0.0080 & 0.7702 & 1.00 & 19737 & 8776 \\
\hline 4 & 0.2488 & 0.0020 & 0.7782 & 1.00 & 22208 & 6759 \\
\hline 5 & 0.2694 & 0.0000 & 0.7639 & 1.00 & 23654 & 5260 \\
\hline 6 & 0.3301 & 0.0002 & 0.7187 & 1.00 & 24484 & 4018 \\
\hline
\end{tabular}

Survival rate of flat sardinella eggs $\left(S_{e}\right)$ is $0.0003 \mathrm{y}^{-1}$ 
Table A3. Life history table of round sardinella in the coastal waters of Ghana

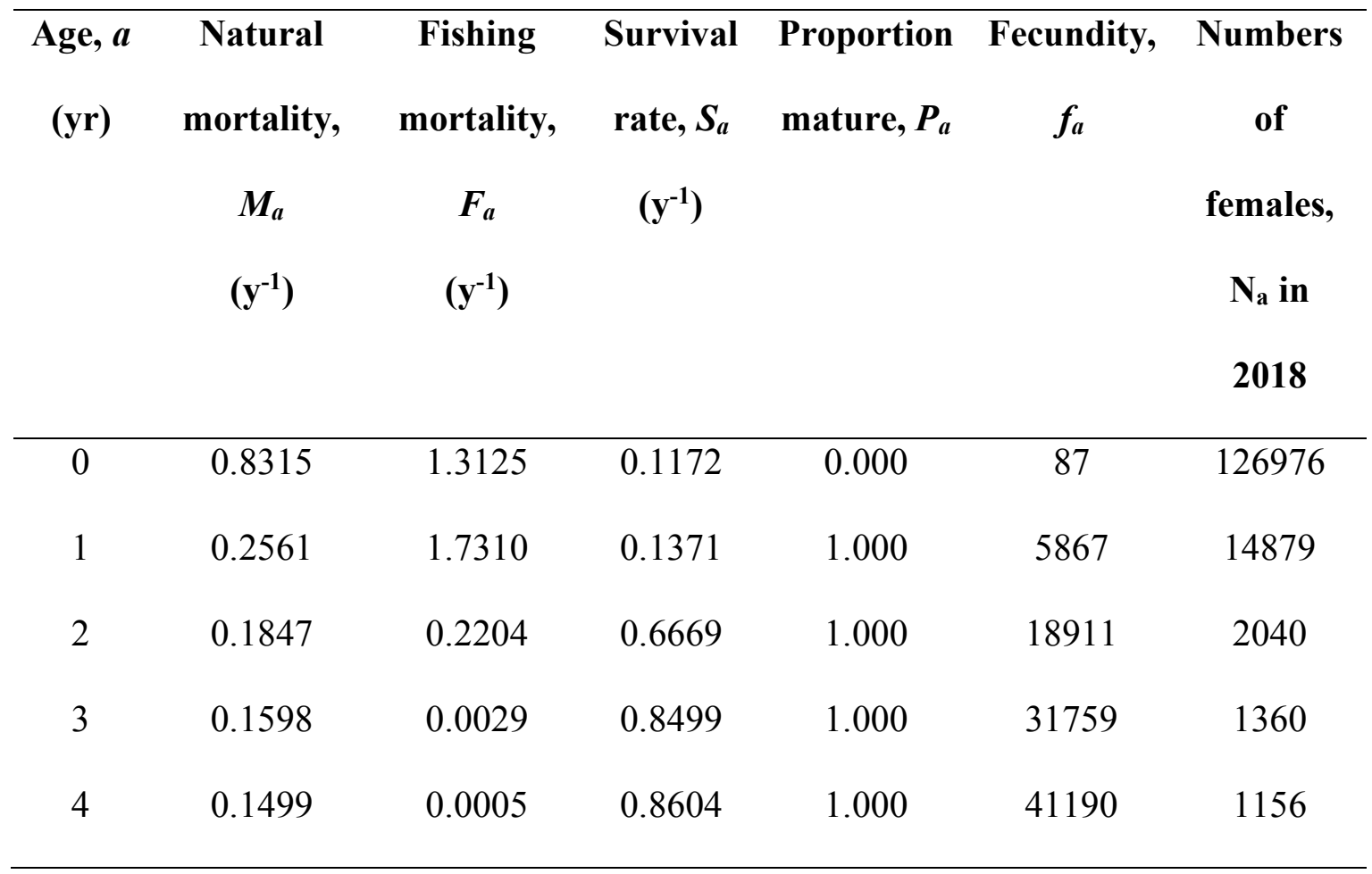

Survival rate of round sardinella eggs $\left(S_{e}\right)$ is $0.0011 \mathrm{y}^{-1}$ 
Table A4. Archetype of the projection matrix for the closed season scenario, $\left(\boldsymbol{M}_{\boldsymbol{x} / \mathbf{I}}\right)$ commencing at time $t$

\begin{tabular}{|c|c|c|c|c|c|c|}
\hline Age (yr) & 0 & 1 & 2 & 3 & 4 & 5 \\
\hline 0 & $\mathbf{B}_{0, t, \text { closure }}$ & $\mathbf{B}_{1, t, \text { closure }}$ & $\mathbf{B}_{2, t, \text { closure }}$ & $\mathbf{B}_{3, t, \text { closure }}$ & $\mathbf{B}_{4, t, \text { closure }}$ & 0 \\
\hline 1 & $S_{0, t, \text { closure }}$ & 0 & 0 & 0 & 0 & 0 \\
\hline 2 & 0 & $\mathbf{S}_{1, \mathrm{t}, \text { closure }}$ & 0 & 0 & 0 & 0 \\
\hline 3 & 0 & 0 & $\mathbf{S}_{2, \mathrm{t}, \text { closure }}$ & 0 & 0 & 0 \\
\hline 4 & 0 & 0 & 0 & $\mathbf{S}_{3, t, \text { closure }}$ & 0 & 0 \\
\hline 5 & 0 & 0 & 0 & 0 & $\mathbf{S}_{4, \mathrm{t}, \text { closure }}$ & 0 \\
\hline
\end{tabular}

Table A5. Archetype of the projection matrix for the fishing season scenario, $\left(\boldsymbol{M}_{12-x / 12}\right)$ which was assumed to follow the fishing closure immediately at time $t+x / 12$

\begin{tabular}{|c|c|c|c|c|c|c|}
\hline Age $(\mathrm{yr})$ & $\mathrm{x} / 12$ & $1-\mathrm{x} / 12$ & $1+\mathrm{x} / 12$ & $2+\mathrm{x} / 12$ & $3+\mathrm{x} / 12$ & $4+\mathrm{x} / 12$ \\
\hline $\mathrm{x} / 12$ & $\mathrm{~S}_{0, \mathrm{x} / 12, \mathrm{fishing}}$ & $\mathrm{B}_{0,1-\mathrm{x} / 12, \mathrm{fishing}}$ & $\mathrm{B}_{1, \mathrm{t}+\mathrm{x} / 12, \mathrm{fishing}}$ & $\mathrm{B}_{2, \mathrm{t}+\mathrm{x} / 12, \mathrm{fishing}}$ & $\mathrm{B}_{3, \mathrm{t}+\mathrm{x} / 12, \mathrm{fishing}}$ & $\mathrm{B}_{4, \mathrm{t}+\mathrm{x} / 12, \mathrm{fishing}}$ \\
\hline $1-\mathrm{x} / 12$ & 0 & $\mathrm{~S}_{0,1-\mathrm{x} / 12, \mathrm{fishing}}$ & 0 & 0 & 0 & 0 \\
\hline $1+\mathrm{x} / 12$ & 0 & 0 & $\mathrm{~S}_{1, \mathrm{t}+\mathrm{x} / 12, \mathrm{fishing}}$ & 0 & 0 & 0 \\
\hline $2+\mathrm{x} / 12$ & 0 & 0 & 0 & $\mathrm{~S}_{2, \mathrm{t}+\mathrm{x} / 12, \mathrm{fishing}}$ & 0 & 0 \\
\hline $3+\mathrm{x} / 12$ & 0 & 0 & 0 & 0 & $\mathrm{~S}_{3, \mathrm{t}+\mathrm{x} / 12, \mathrm{fishing}}$ & 0 \\
\hline $4+\mathrm{x} / 12$ & 0 & 0 & 0 & 0 & 0 & $\mathrm{~S}_{4, \mathrm{t}+\mathrm{x} / 12, \mathrm{fishing}}$ \\
\hline
\end{tabular}




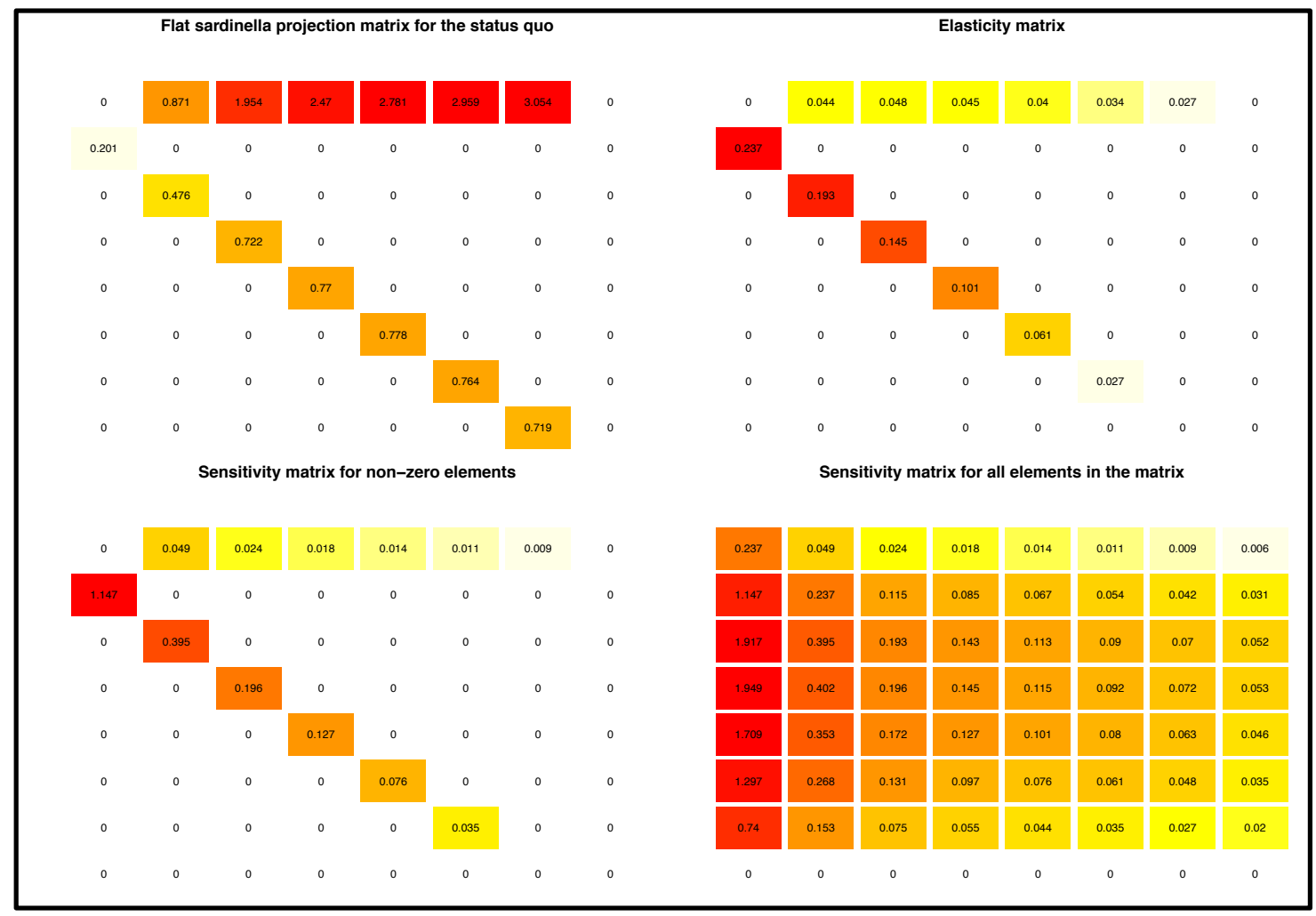

Fig. A18. Sardinella maderensis projection matrix with the sensitivities and elasticities for the fertility and survival rates of the fish for the status quo scenario. 


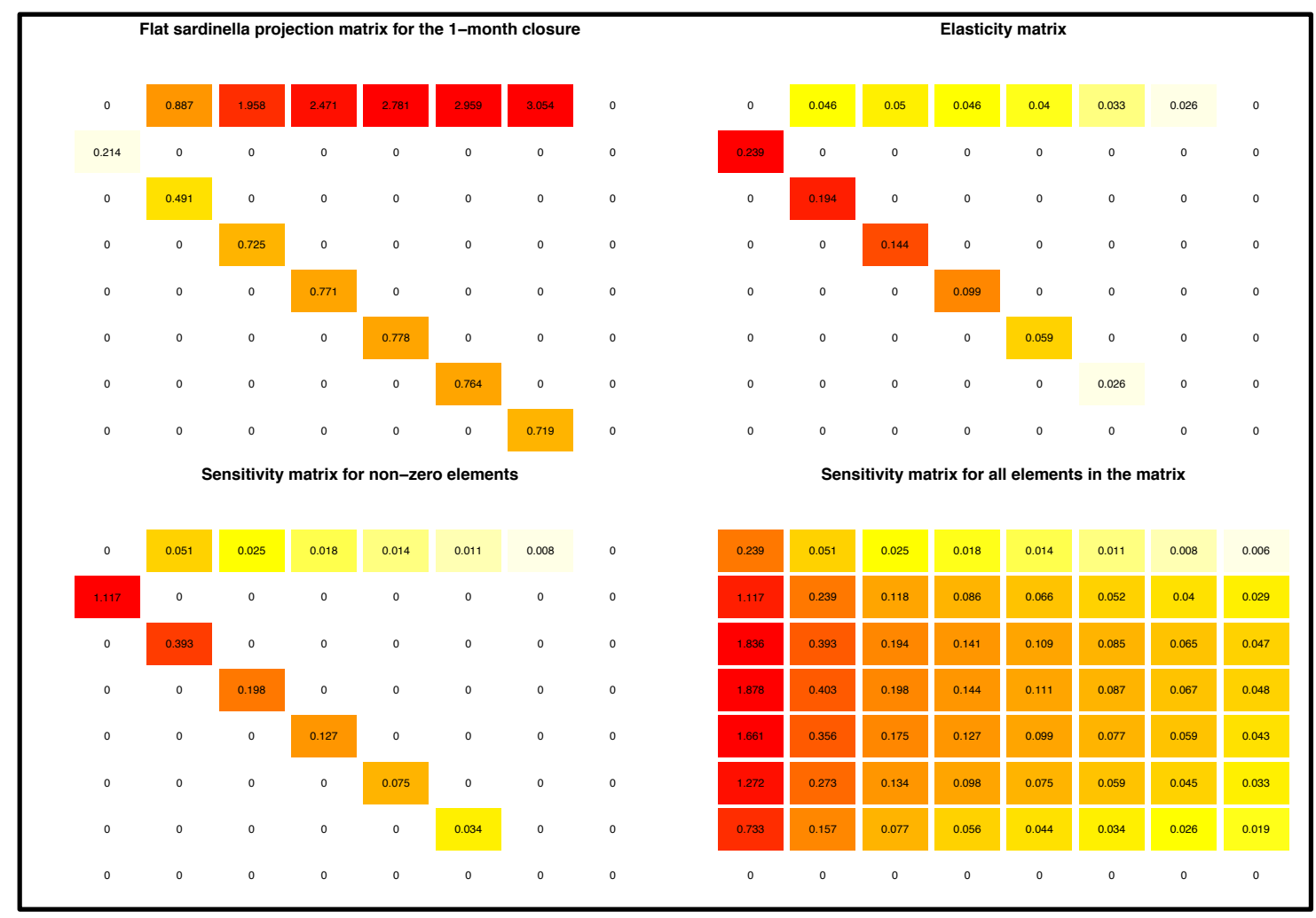

Fig. A19. Sardinella maderensis projection matrix with the sensitivities and elasticities for the fertility and survival rates of the fish for the 1-month closure without any gear restrictions. 


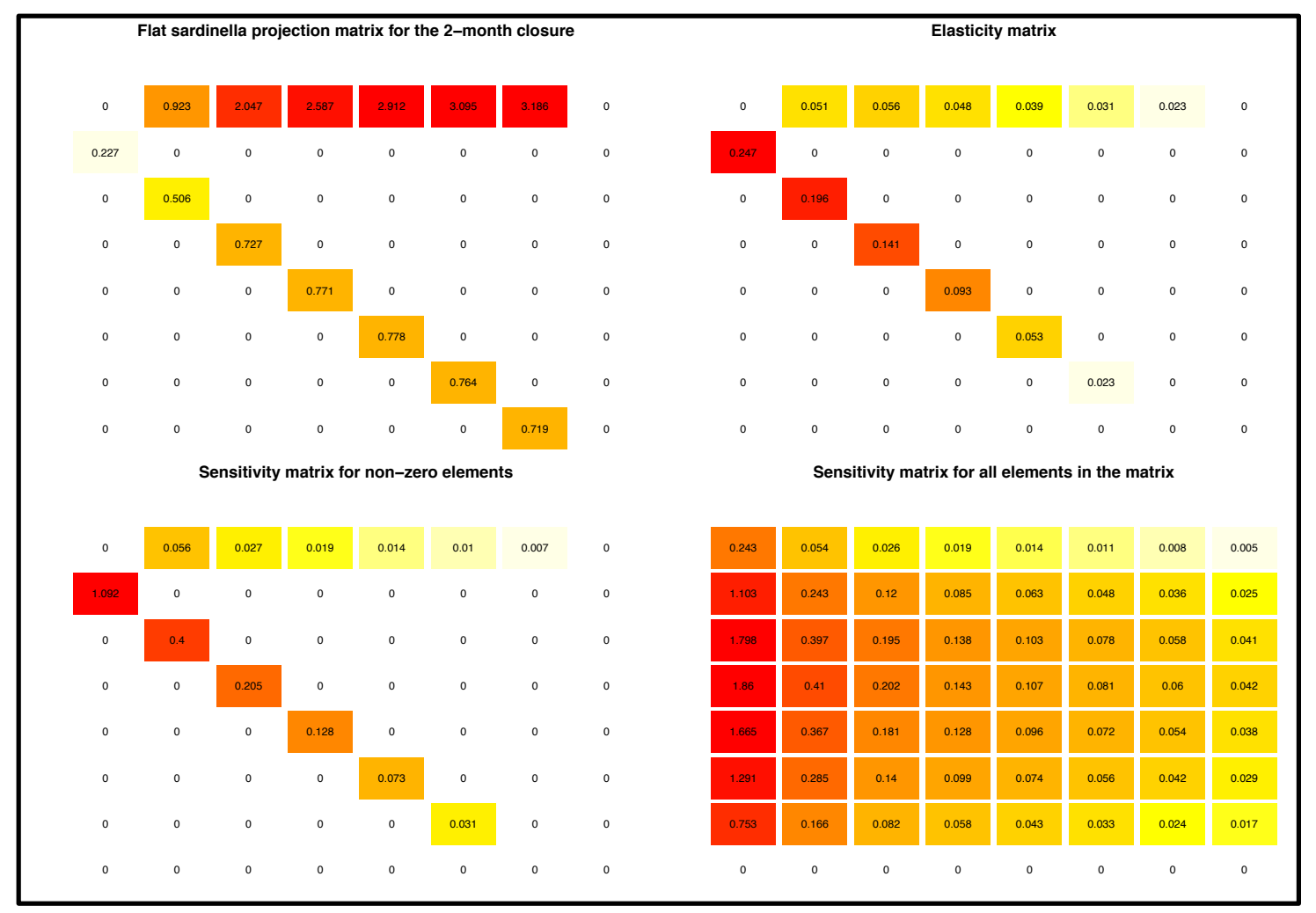

Fig. A20. Sardinella maderensis projection matrix with the sensitivities and elasticities for the fertility and survival rates of the fish for the 2-month closure without any gear restrictions. 


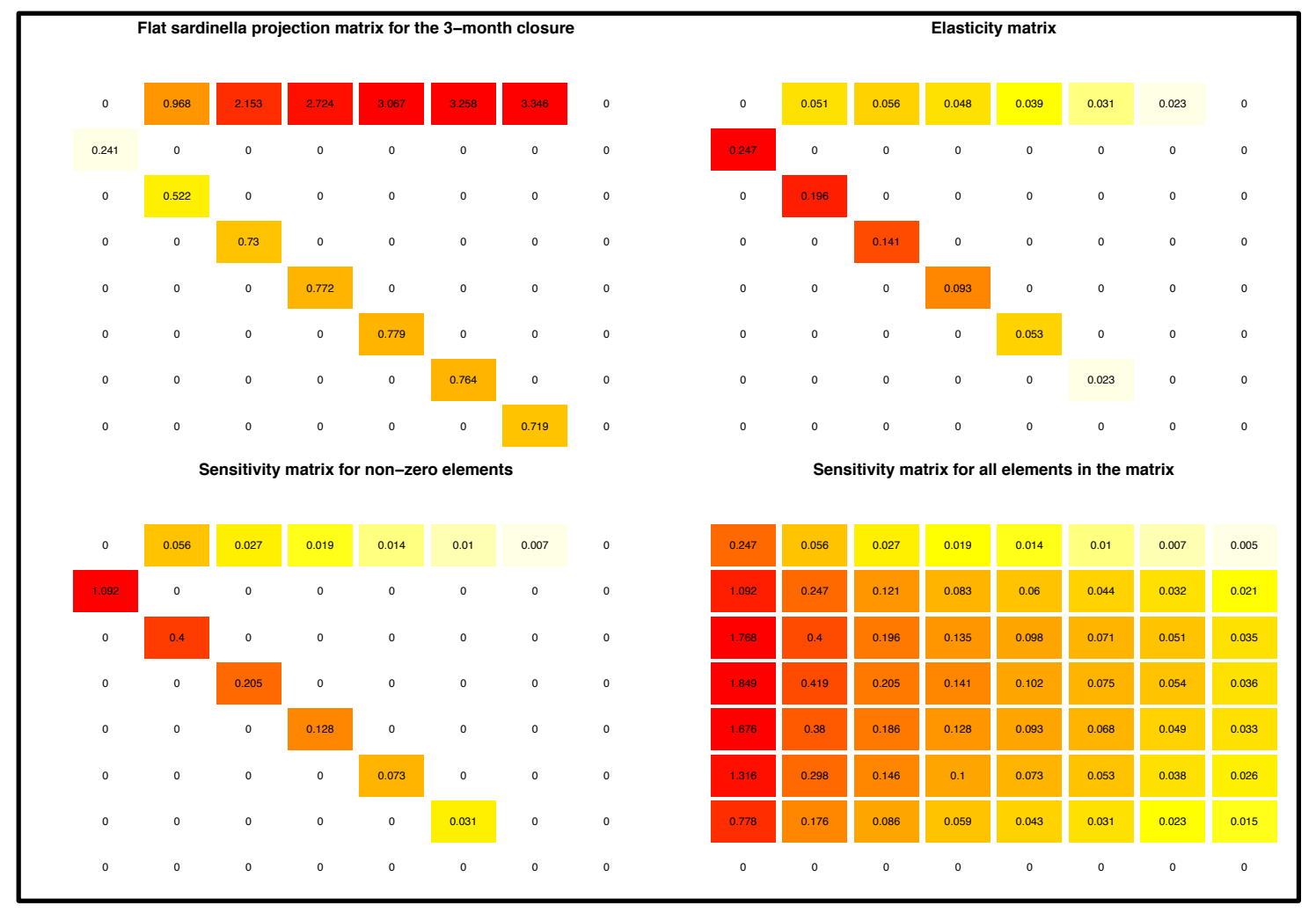

Fig. A21. Sardinella maderensis projection matrix with the sensitivities and elasticities for the fertility and survival rates of the fish for the 3-month closure without any gear restrictions. 


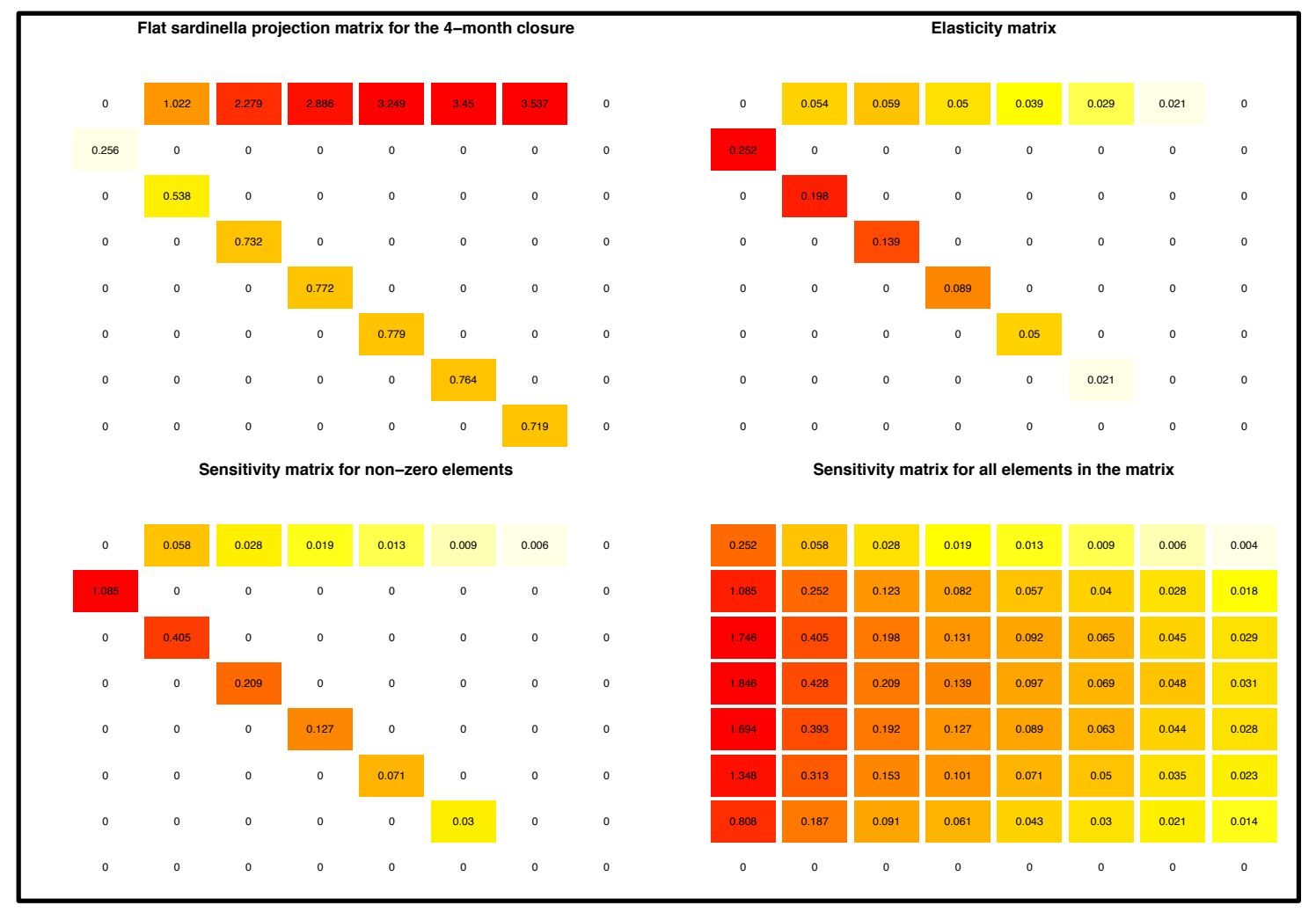

Fig. A22. Sardinella maderensis projection matrix with the sensitivities and elasticities for the fertility and survival rates of the fish for the 4-month closure without any gear restrictions. 


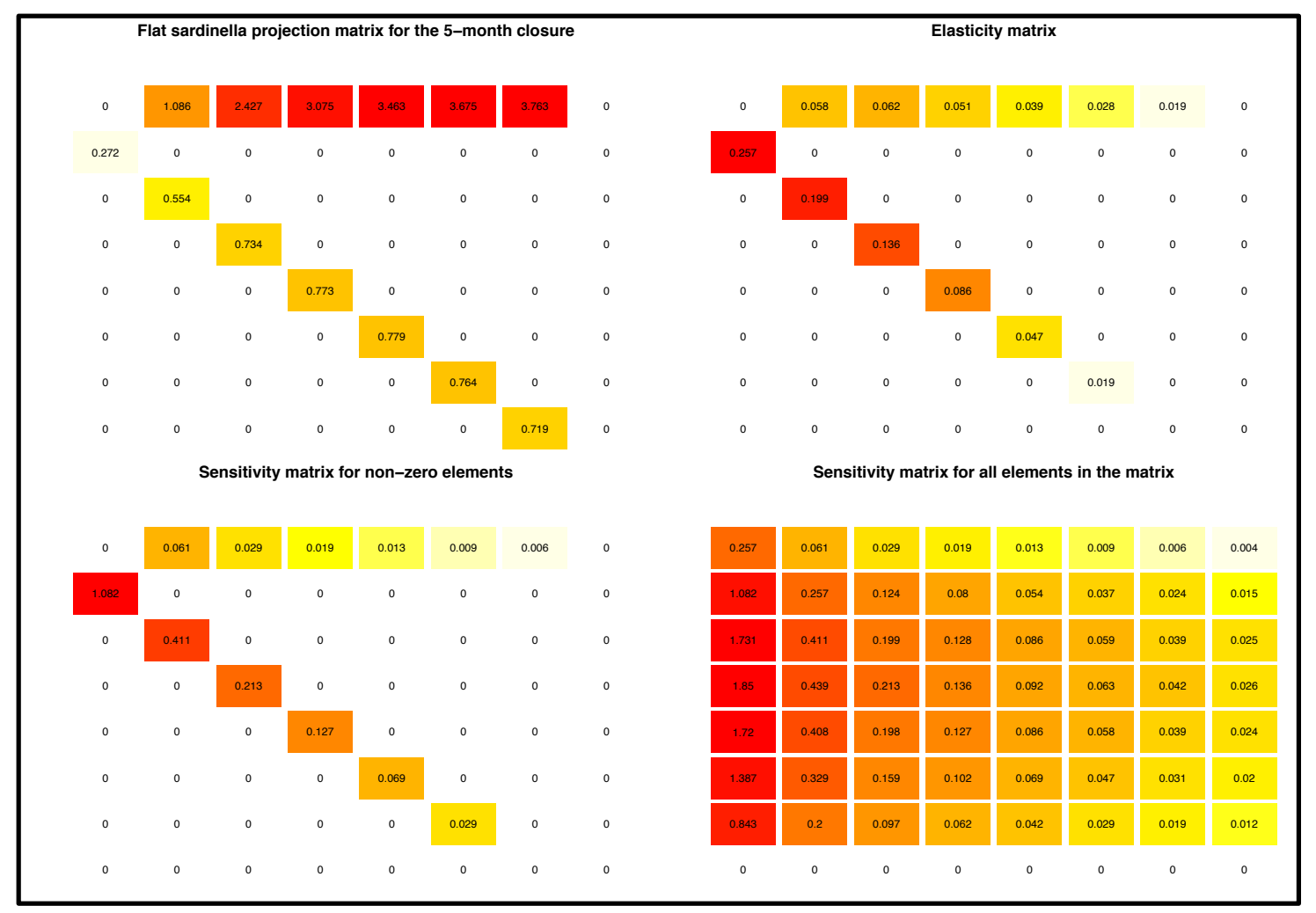

Fig. A23. Sardinella maderensis projection matrix with the sensitivities and elasticities for the fertility and survival rates of the fish for the 5-month closure without any gear restrictions. 


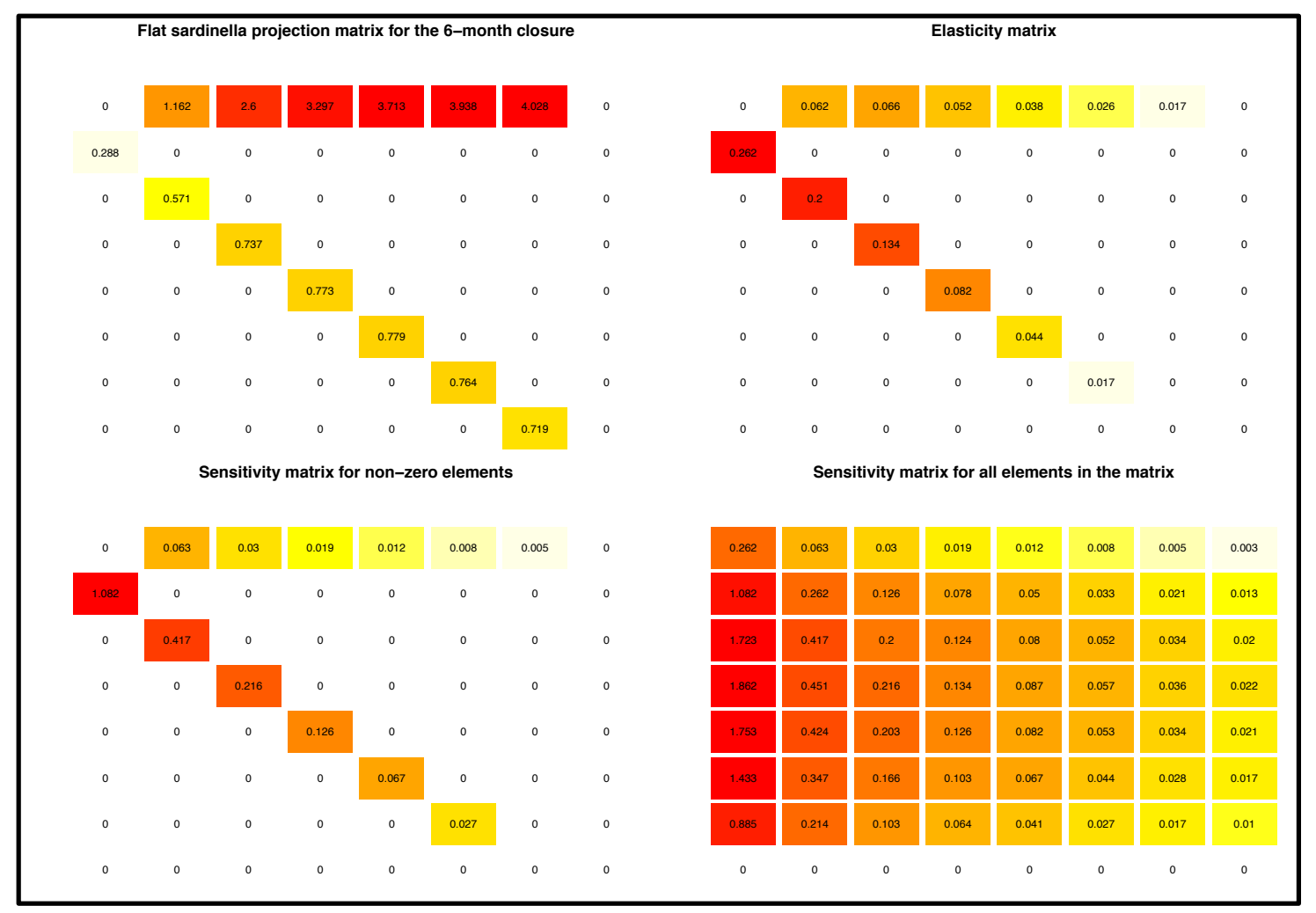

Fig. A24. Sardinella maderensis projection matrix with the sensitivities and elasticities for the fertility and survival rates of the fish for the 6-month closure without any gear restrictions. 


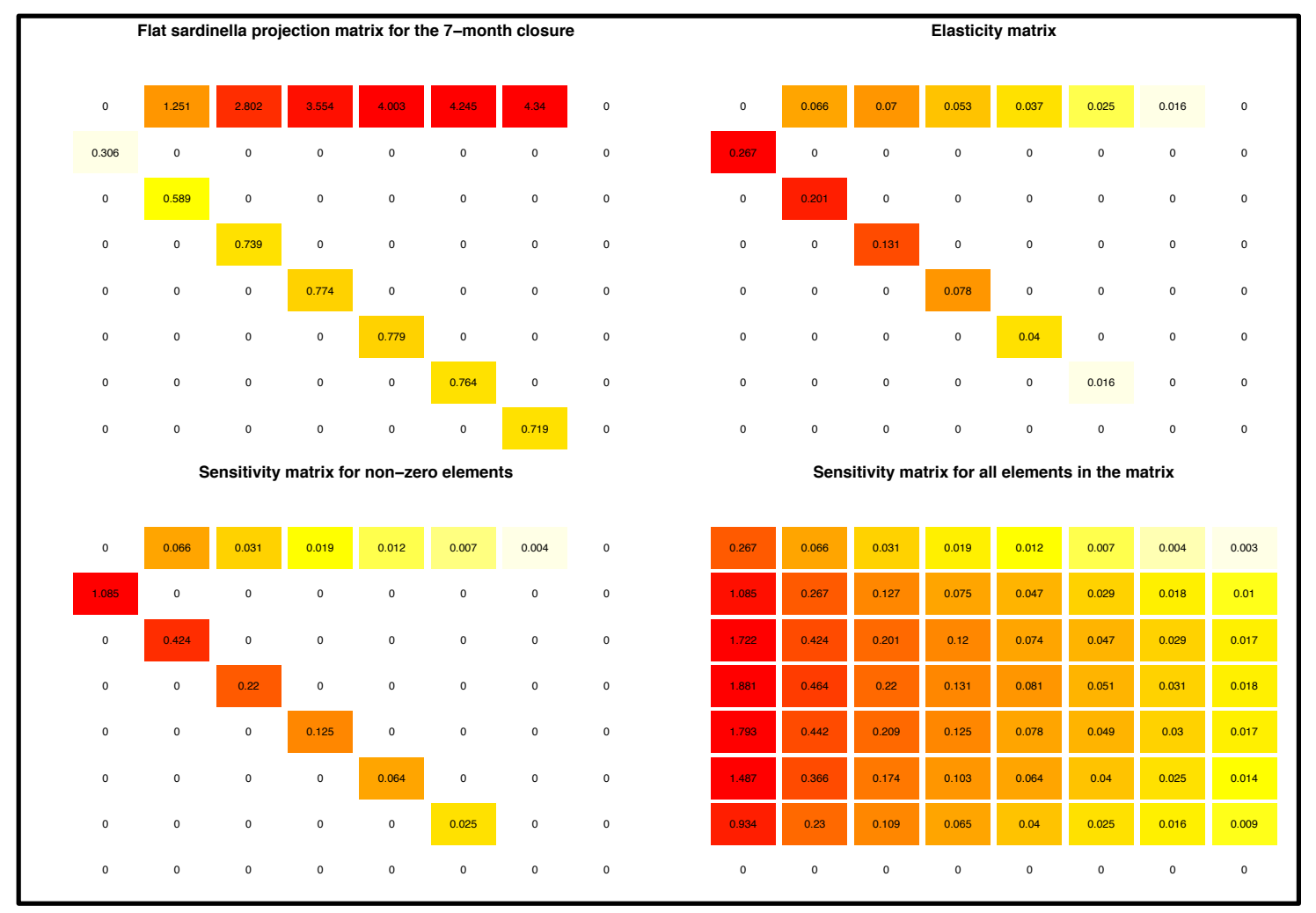

Fig. A25. Sardinella maderensis projection matrix with the sensitivities and elasticities for the fertility and survival rates of the fish for the 7-month closure without any gear restrictions. 


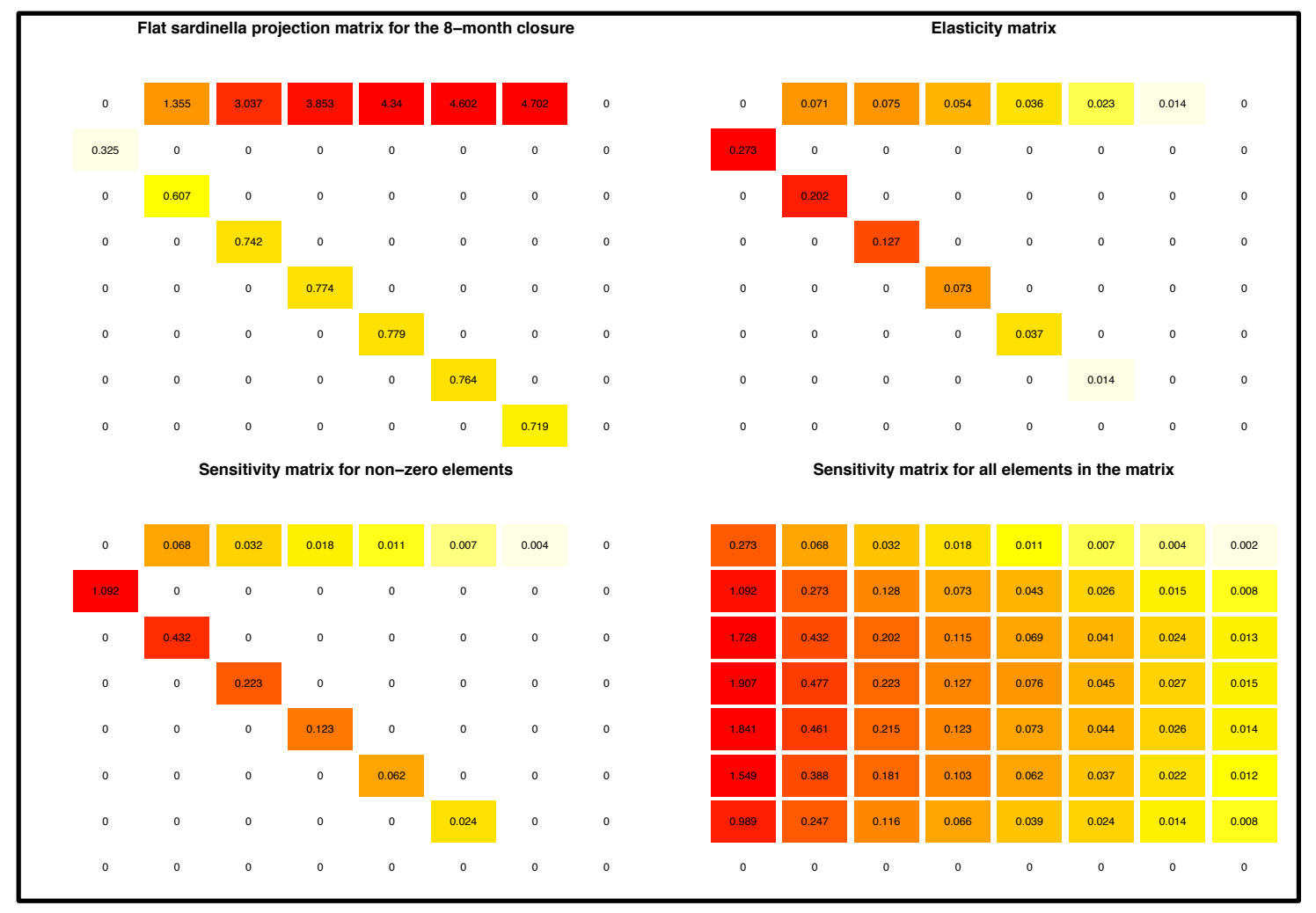

Fig. A26. Sardinella maderensis projection matrix with the sensitivities and elasticities for the fertility and survival rates of the fish for the 8-month closure without any gear restrictions. 


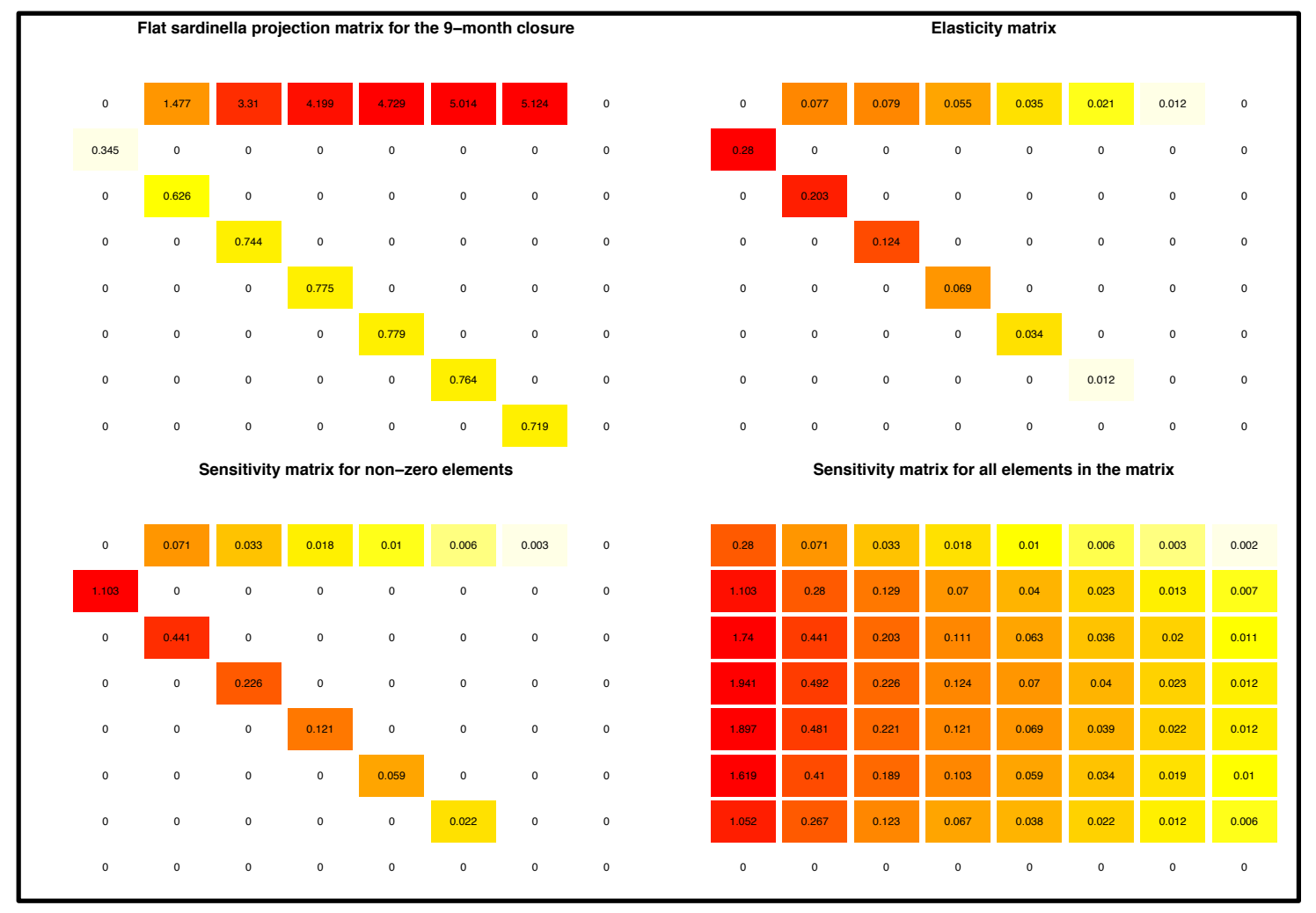

Fig. A27. Sardinella maderensis projection matrix with the sensitivities and elasticities for the fertility and survival rates of the fish for the 9-month closure without any gear restrictions. 


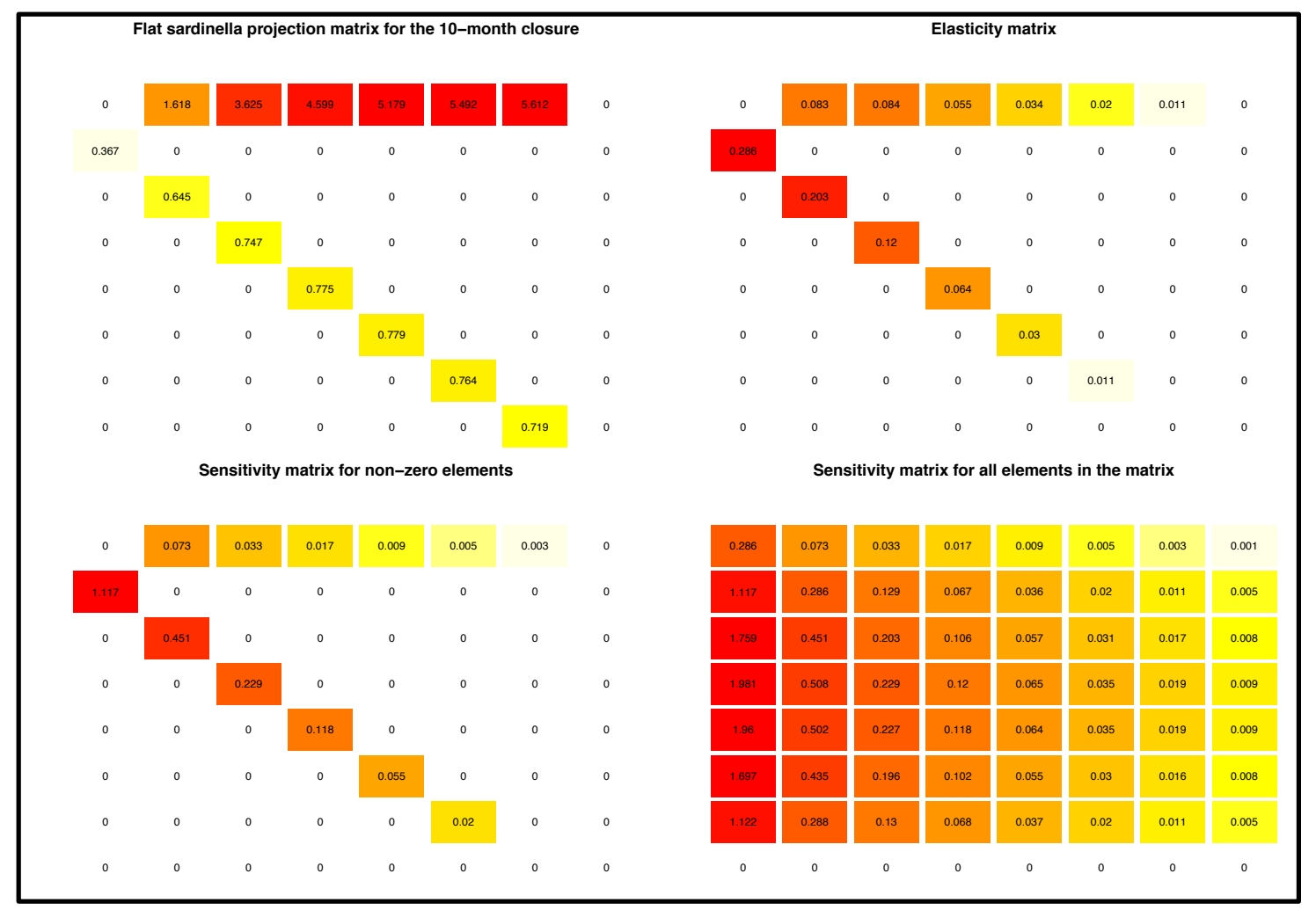

Fig. A28. Sardinella maderensis projection matrix with the sensitivities and elasticities for the fertility and survival rates of the fish for the 10-month closure without any gear restrictions. 


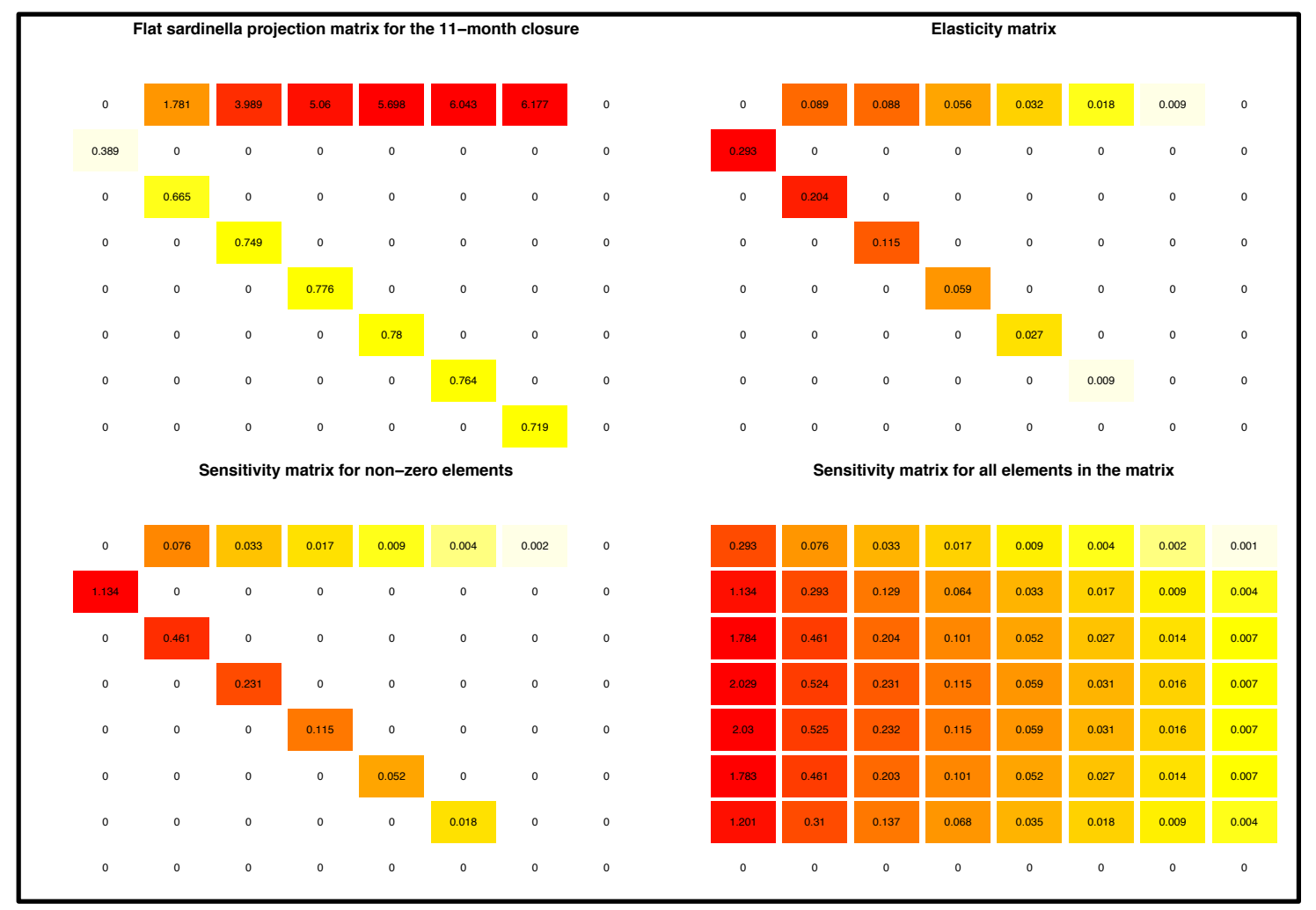

Fig. A29. Sardinella maderensis projection matrix with the sensitivities and elasticities for the fertility and survival rates of the fish for the 11-month closure without any gear restrictions. 


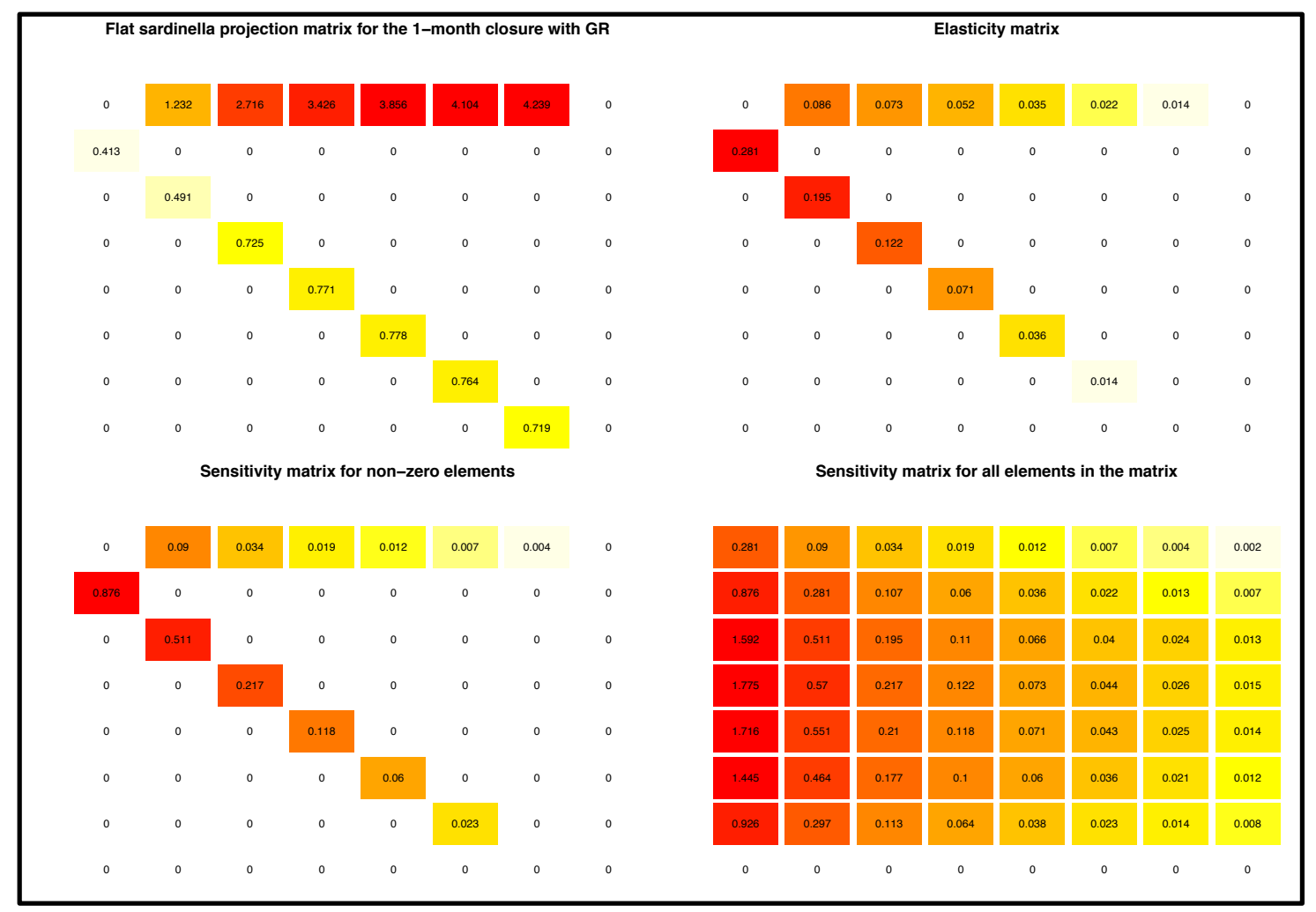

Fig. A30. Sardinella maderensis projection matrix with the sensitivities and elasticities for the fertility and survival rates of the fish for the 1-month closure with gear restrictions. 


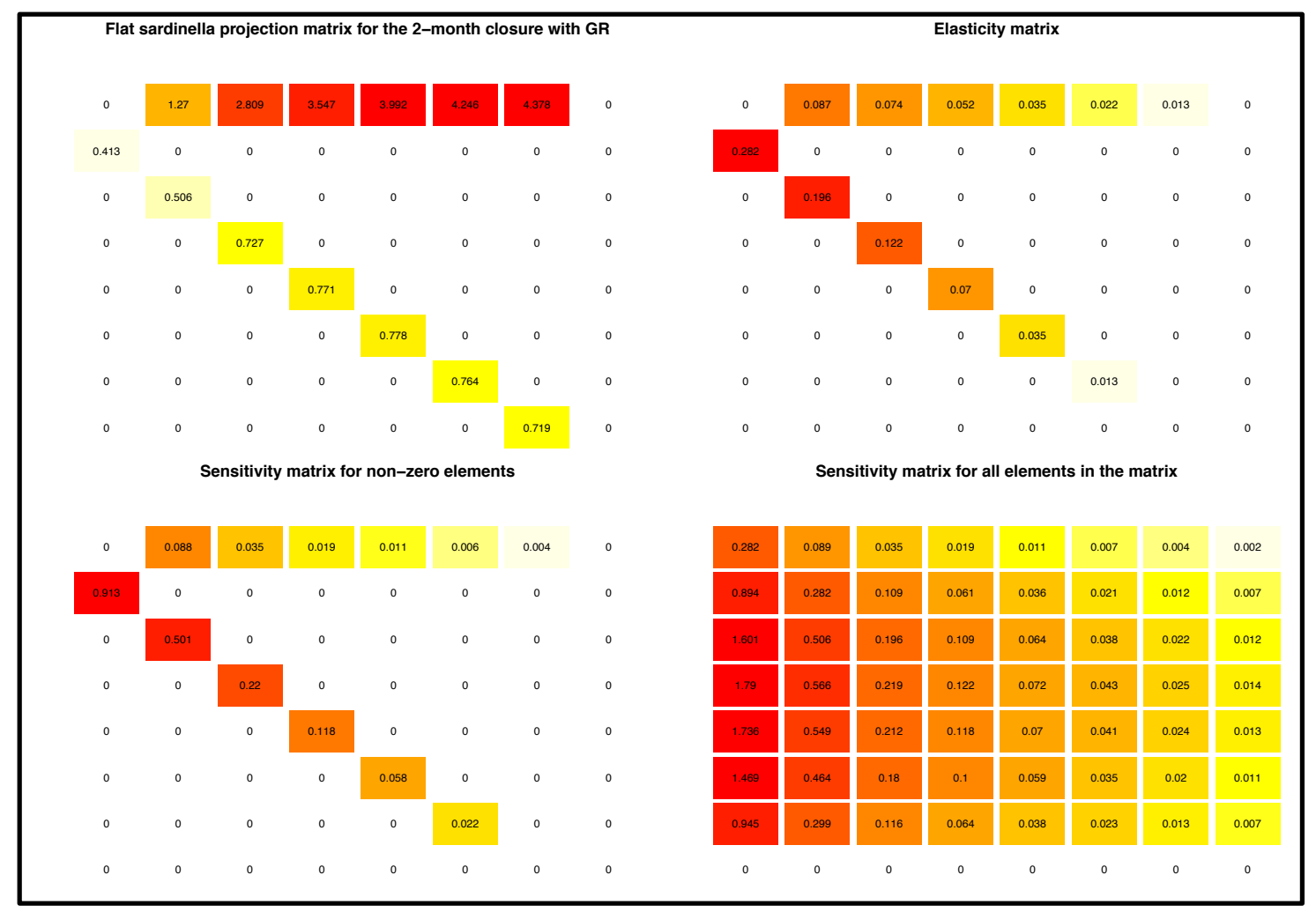

Fig. A31. Sardinella maderensis projection matrix with the sensitivities and elasticities for the fertility and survival rates of the fish for the 2-month closure with gear restrictions. 


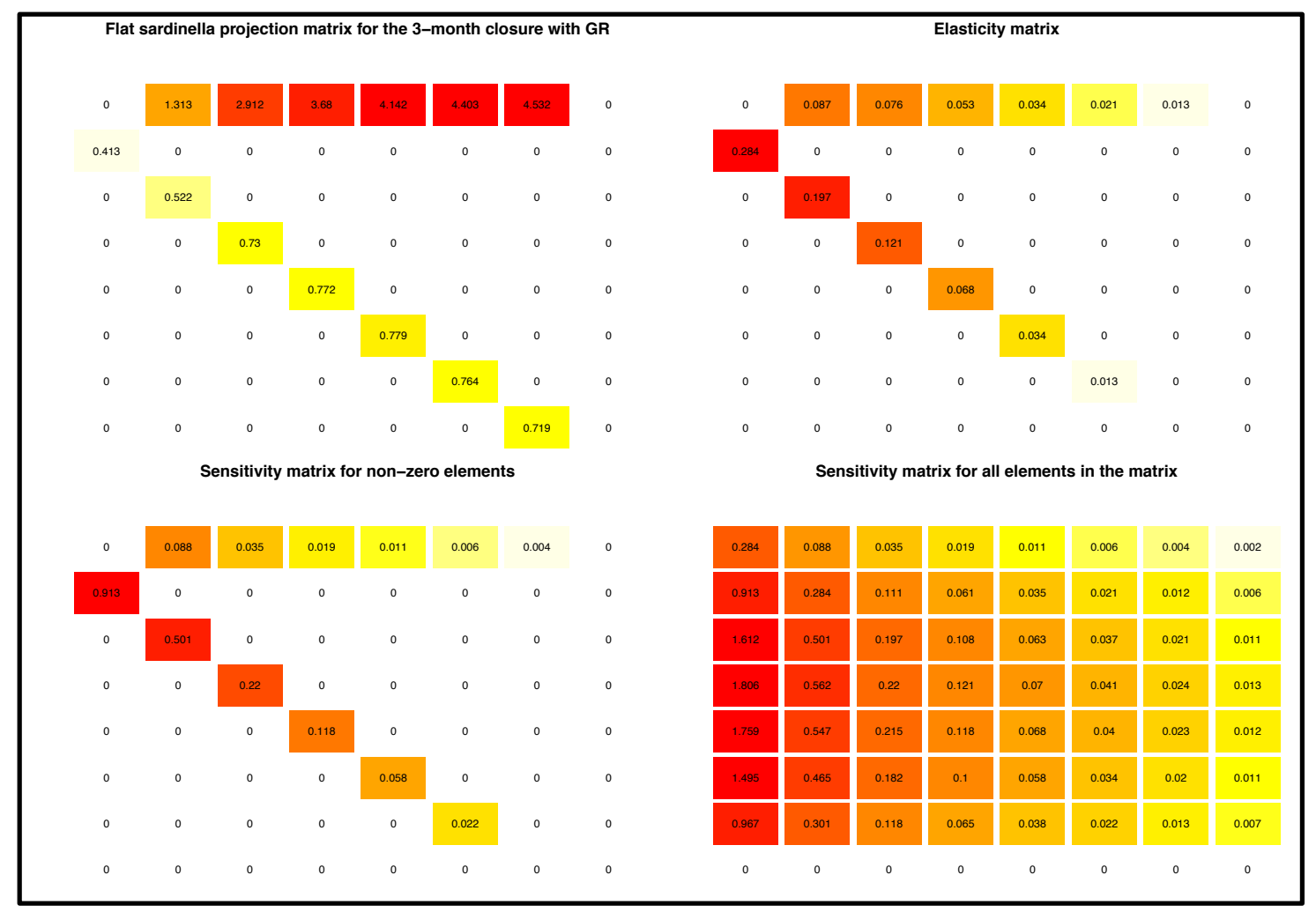

Fig. A32. Sardinella maderensis projection matrix with the sensitivities and elasticities for the fertility and survival rates of the fish for the 3-month closure with gear restrictions. 


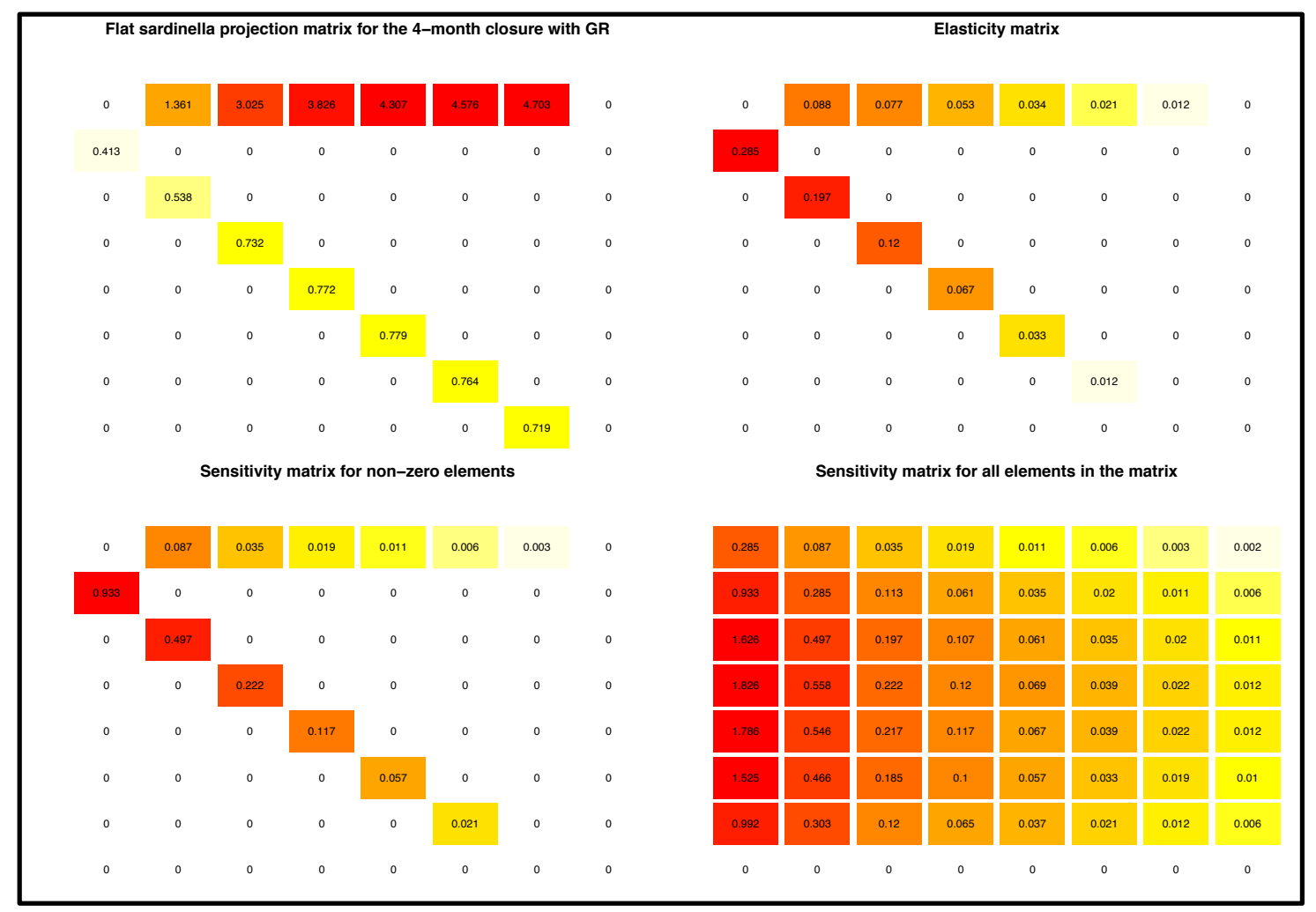

Fig. A33. Sardinella maderensis projection matrix with the sensitivities and elasticities for the fertility and survival rates of the fish for the 4-month closure with gear restrictions. 


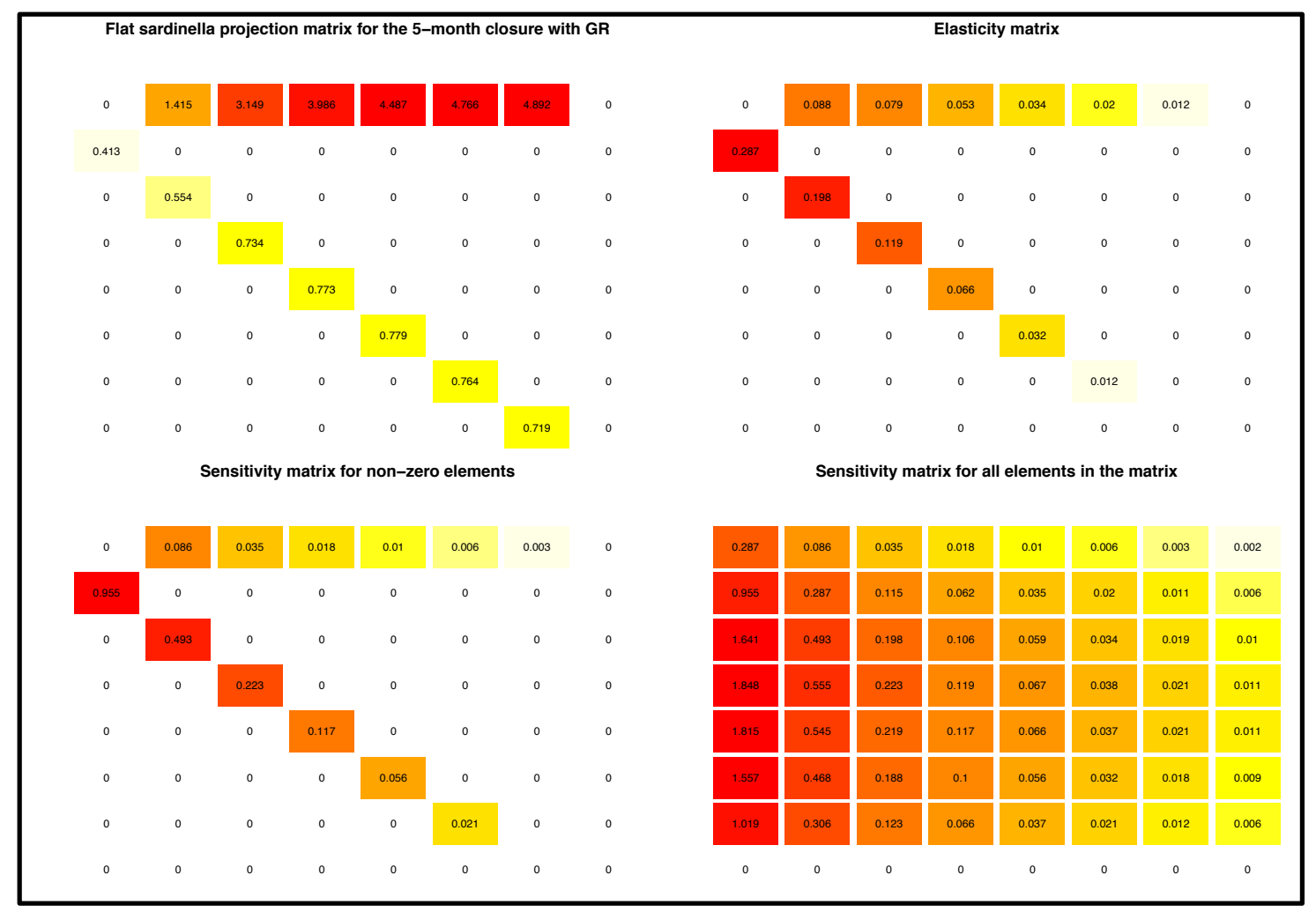

Fig. A34. Sardinella maderensis projection matrix with the sensitivities and elasticities for the fertility and survival rates of the fish for the 5-month closure with gear restrictions. 


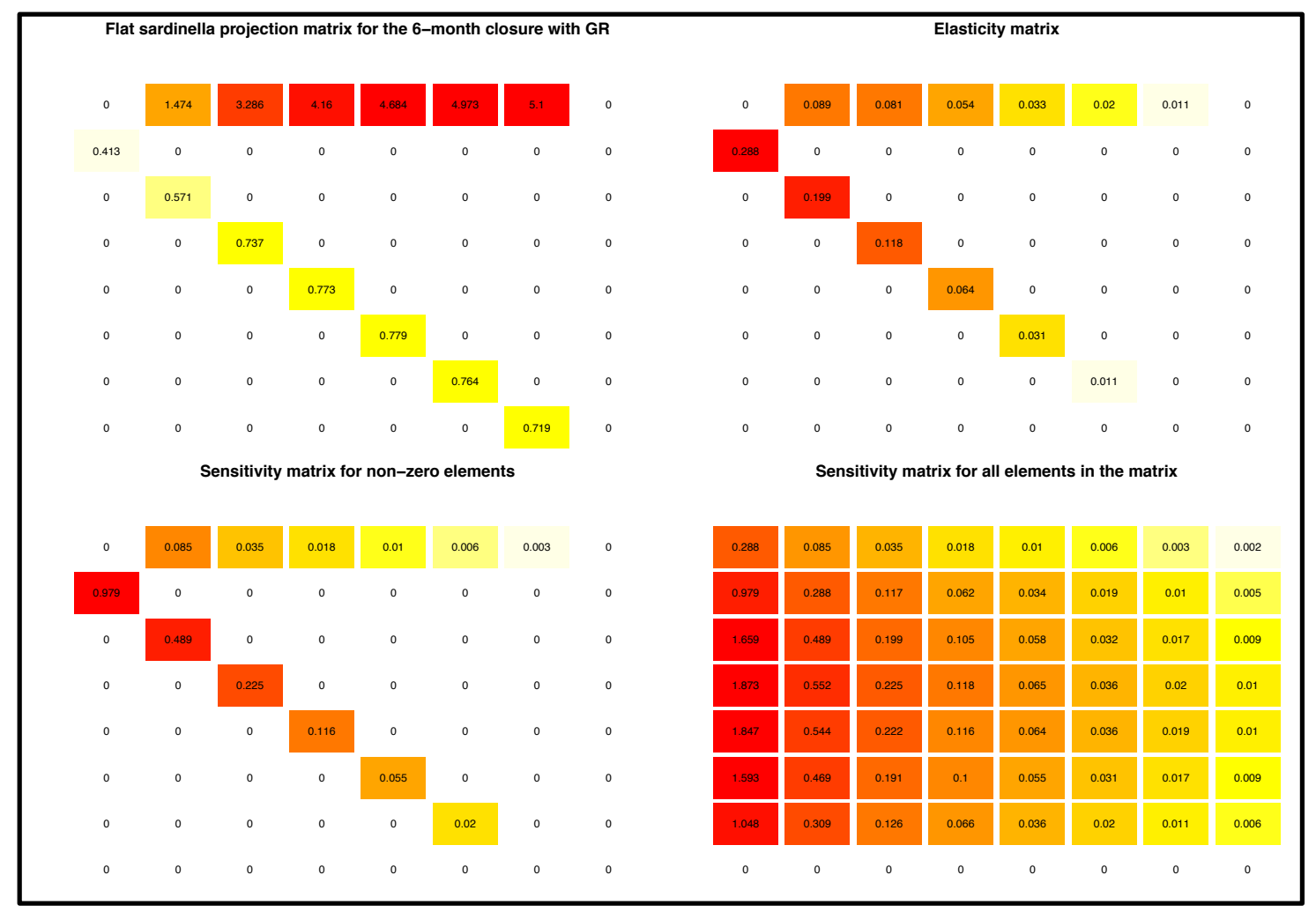

Fig. A35. Sardinella maderensis projection matrix with the sensitivities and elasticities for the fertility and survival rates of the fish for the 6-month closure with gear restrictions. 


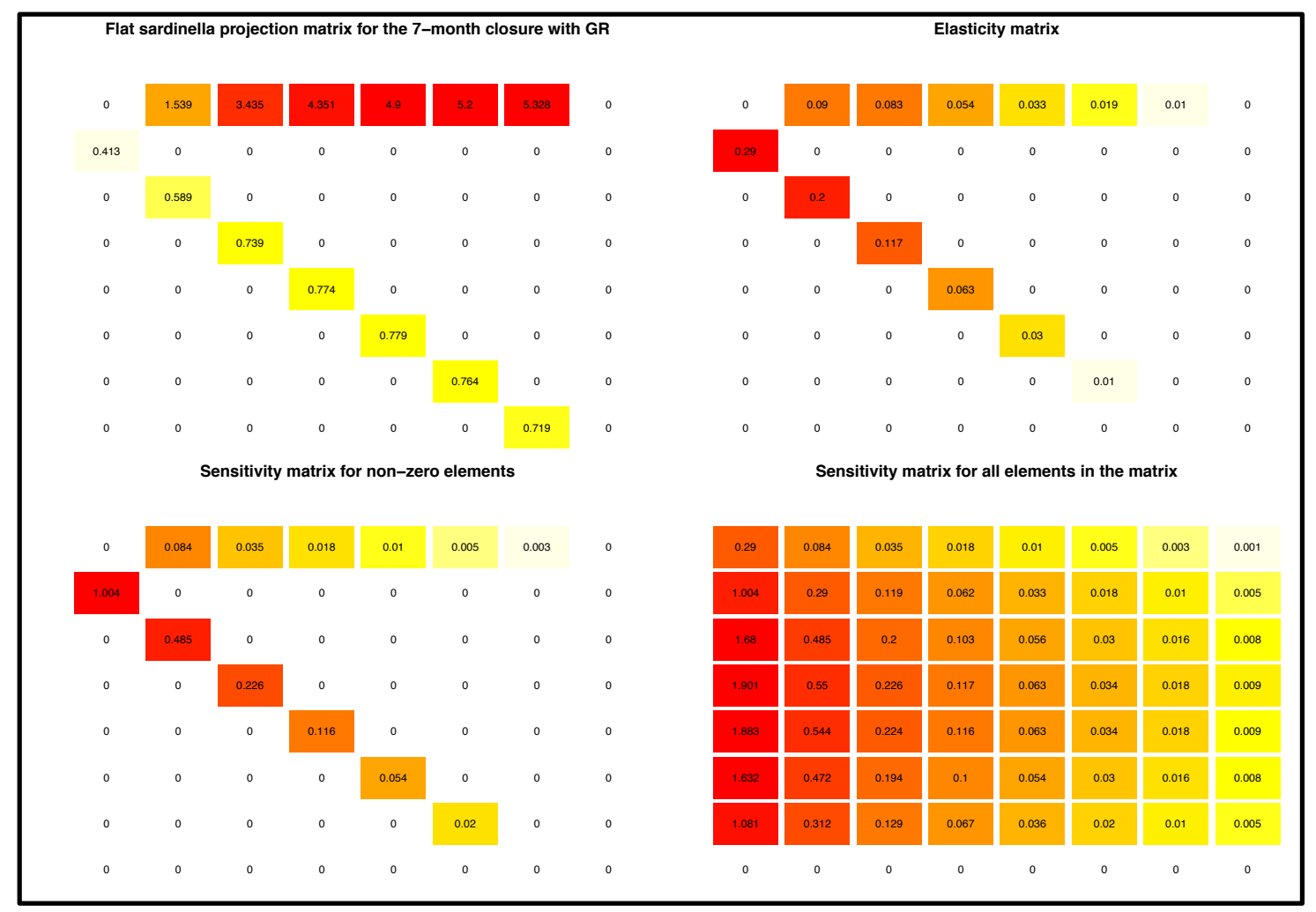

Fig. A36. Sardinella maderensis projection matrix with the sensitivities and elasticities for the fertility and survival rates of the fish for the 7-month closure with gear restrictions. 


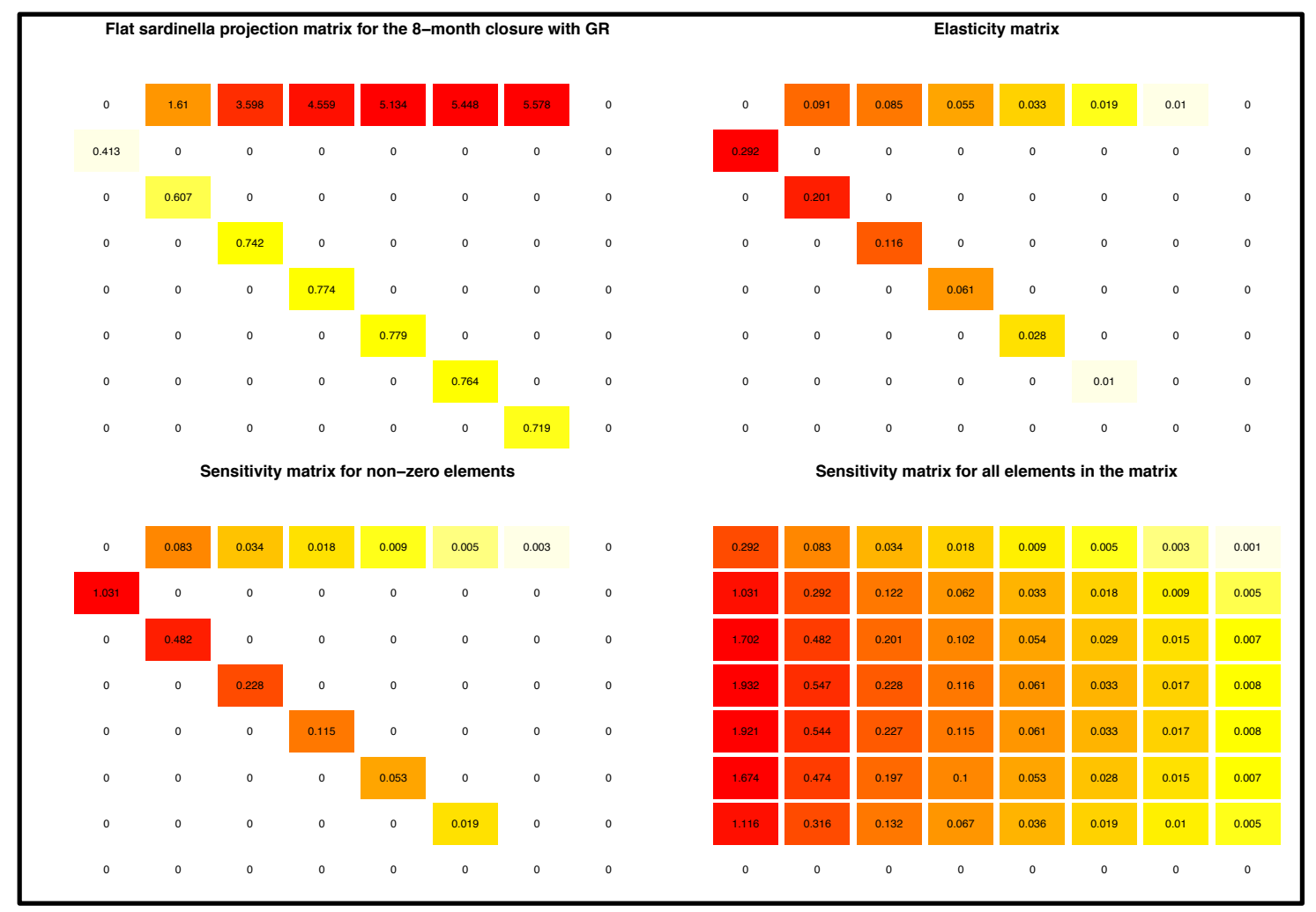

Fig. A37. Sardinella maderensis projection matrix with the sensitivities and elasticities for the fertility and survival rates of the fish for the 8-month closure with gear restrictions. 


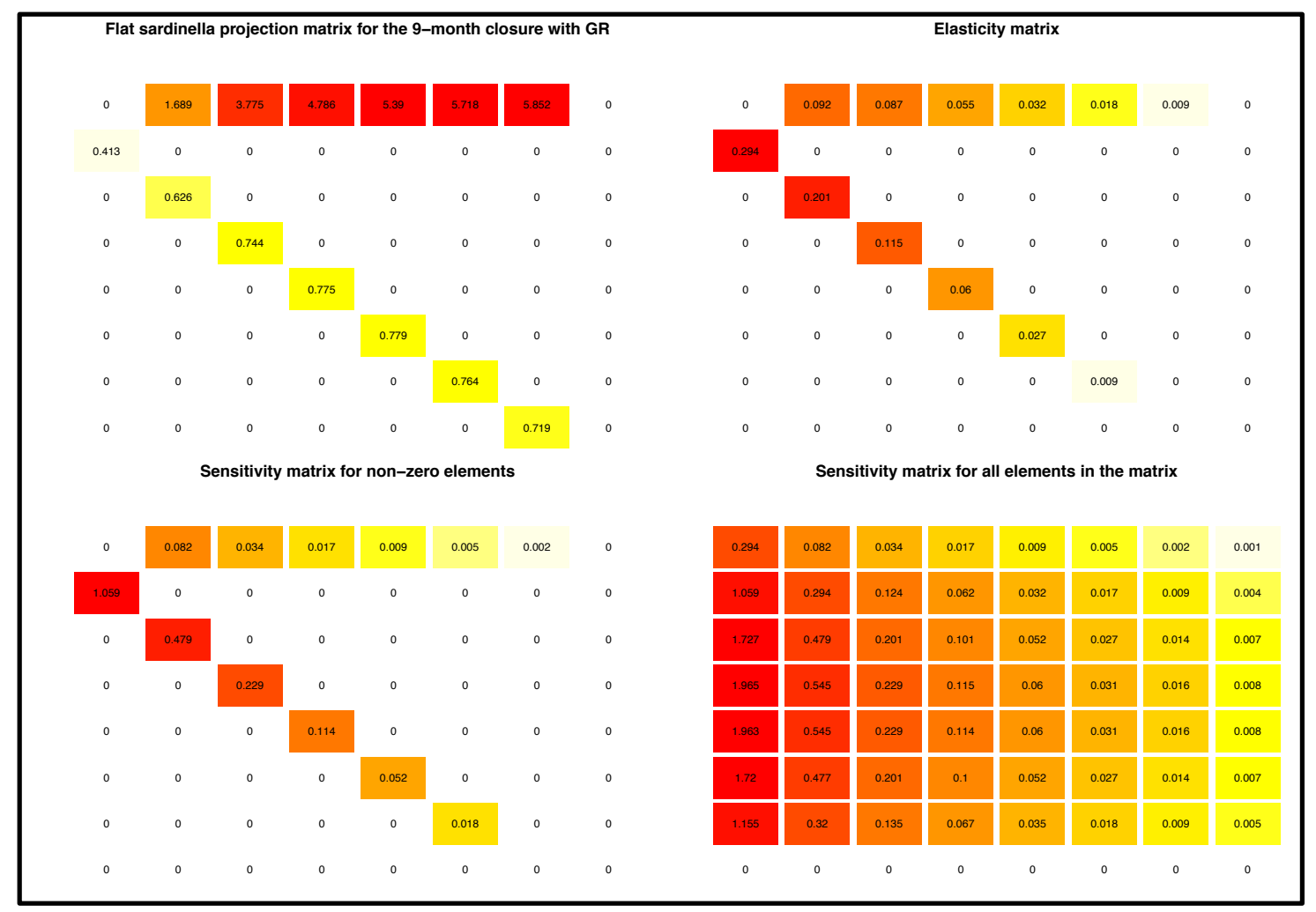

Fig. A38. Sardinella maderensis projection matrix with the sensitivities and elasticities for the fertility and survival rates of the fish for the 9-month closure with gear restrictions. 


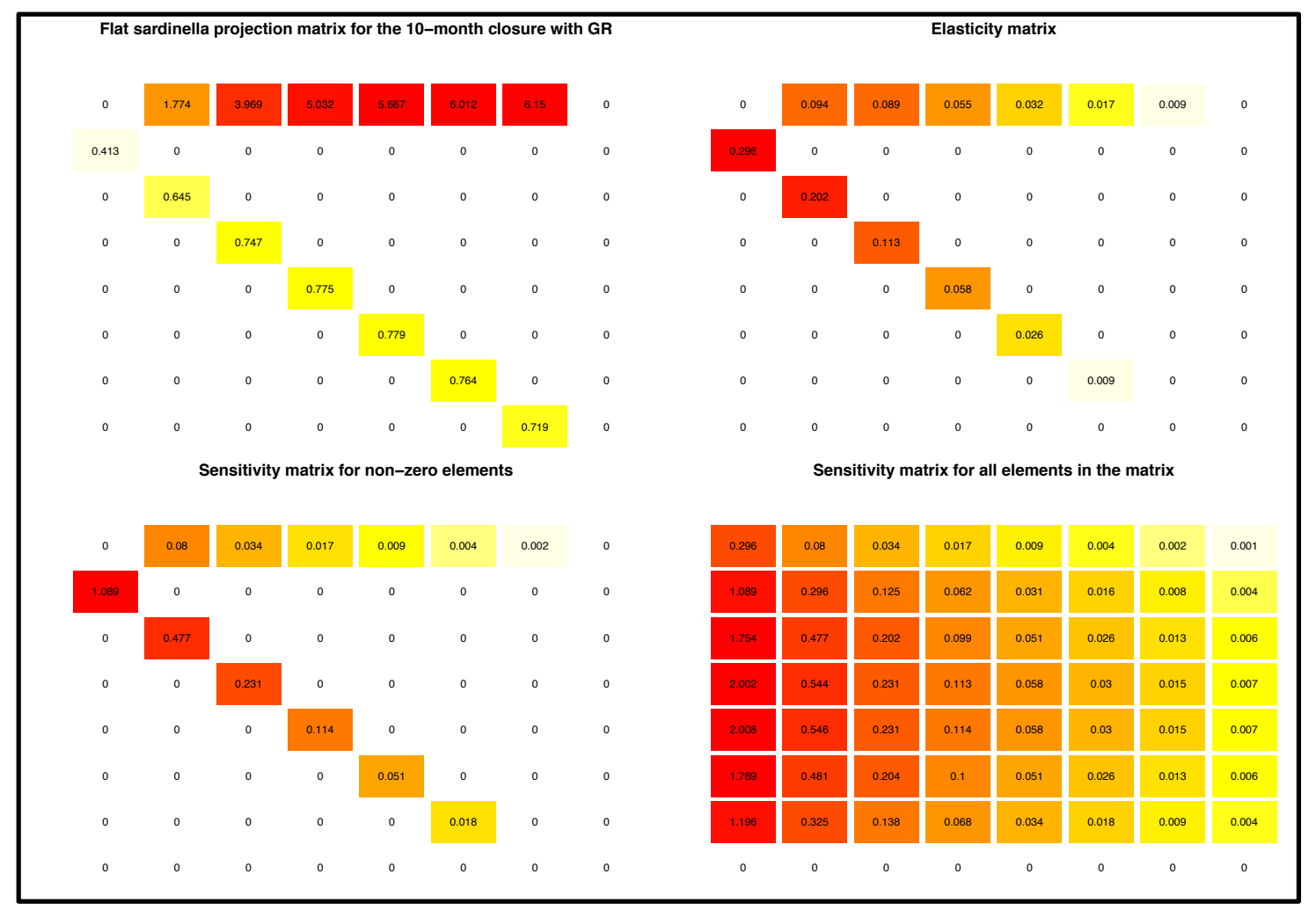

Fig. A39. Sardinella maderensis projection matrix with the sensitivities and elasticities for the fertility and survival rates of the fish for the 10-month closure with gear restrictions. 


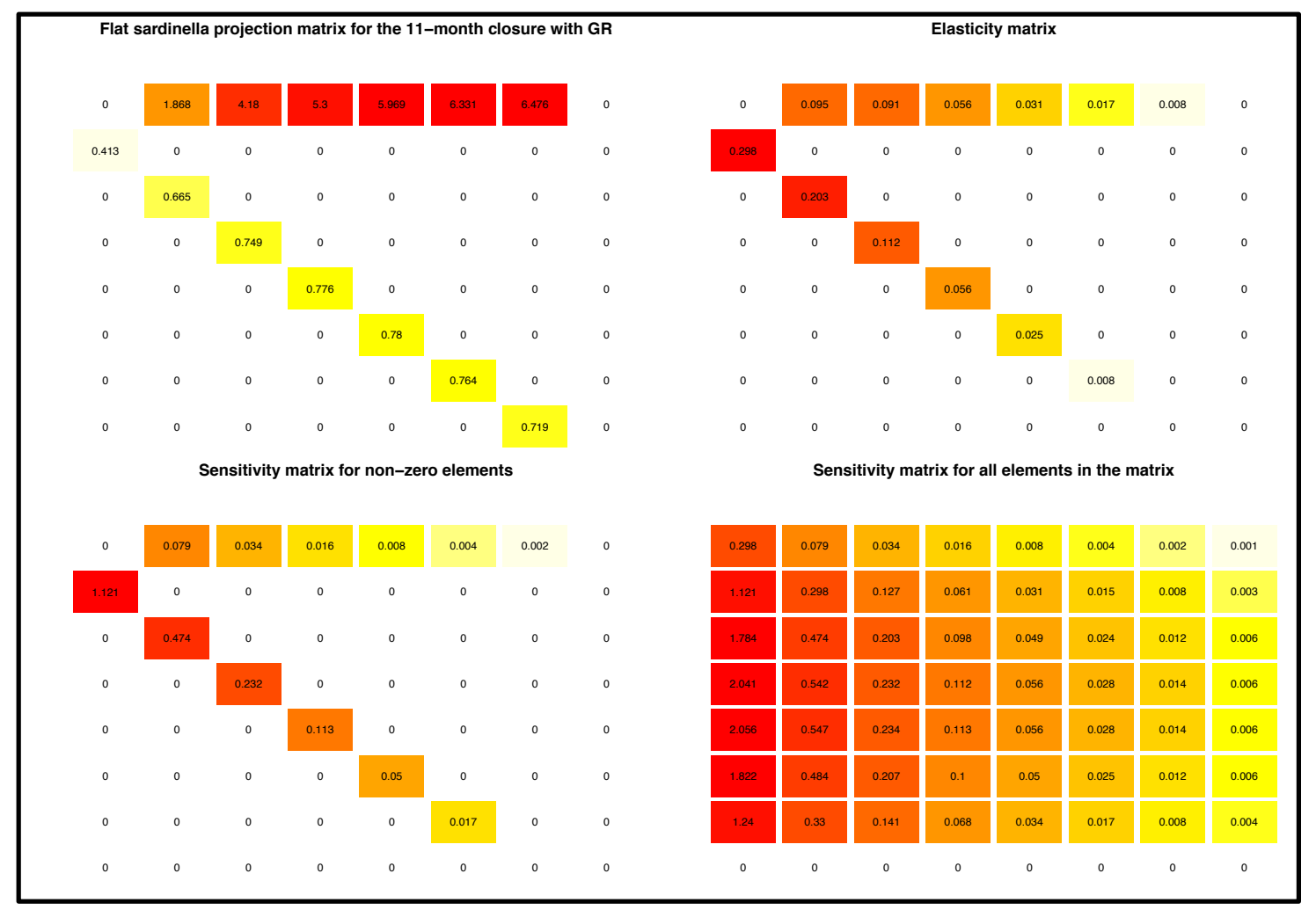

Fig. A40. Sardinella maderensis projection matrix with the sensitivities and elasticities for the fertility and survival rates of the fish for the 11-month closure with gear restrictions. 


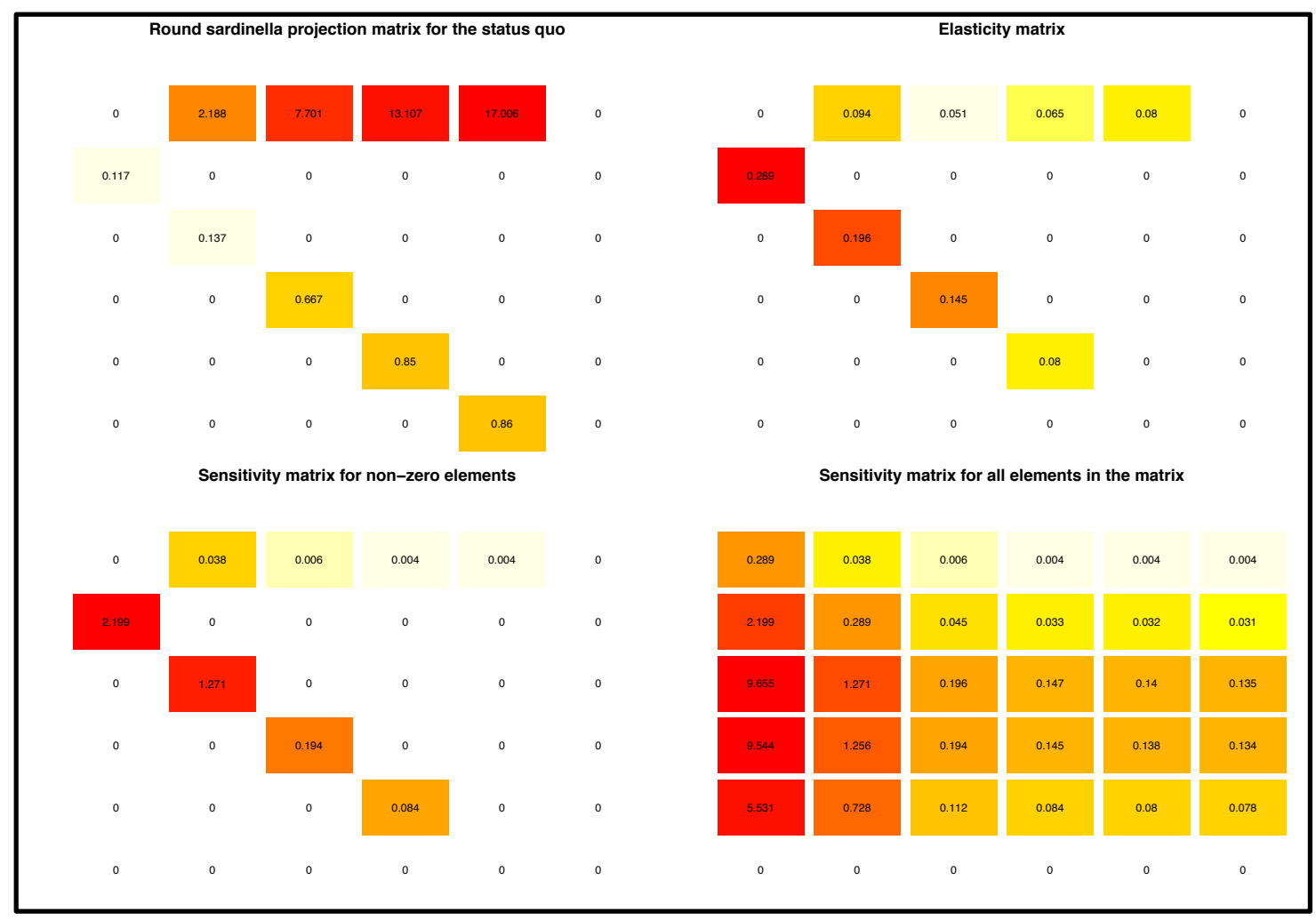

Fig. A41. Sardinella aurita projection matrix with the sensitivities and elasticities for the fertility and survival rates of the fish for the status quo scenario. 


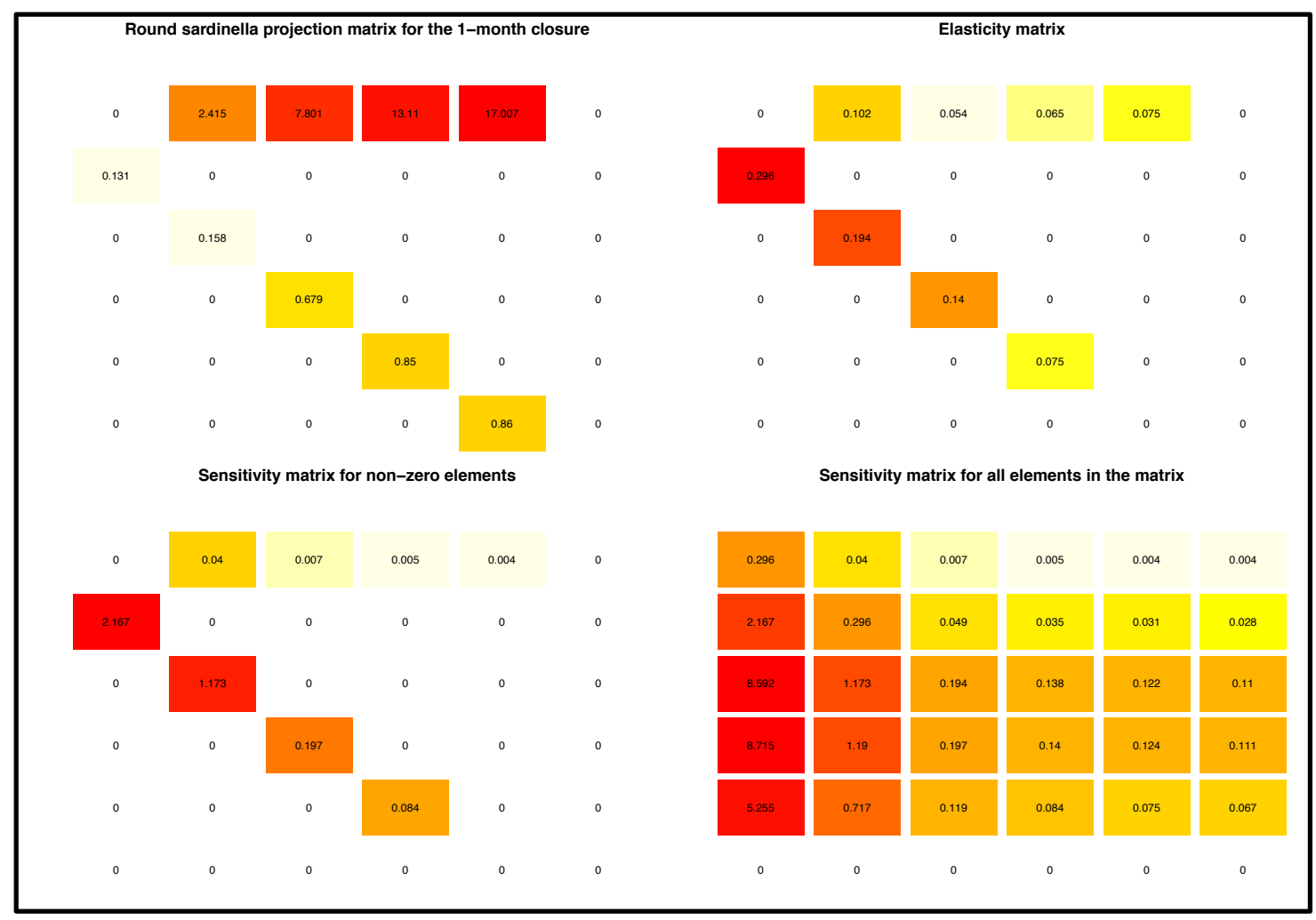

Fig. A42. Sardinella aurita projection matrix with the sensitivities and elasticities for the fertility and survival rates of the fish for the 1-month closure without any gear restrictions. 


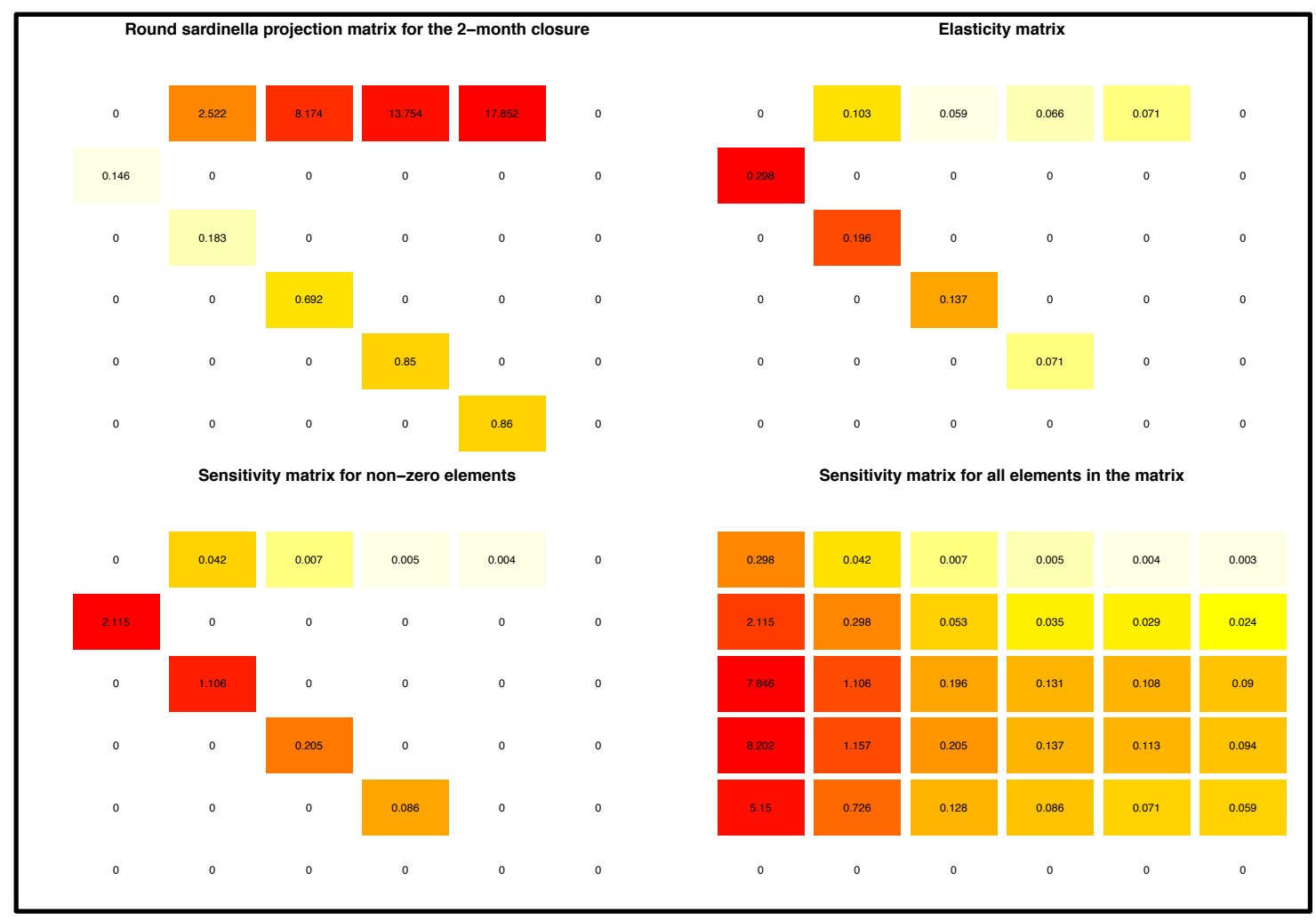

Fig. A43. Sardinella aurita projection matrix with the sensitivities and elasticities for the fertility and survival rates of the fish for the 2-month closure without any gear restrictions. 


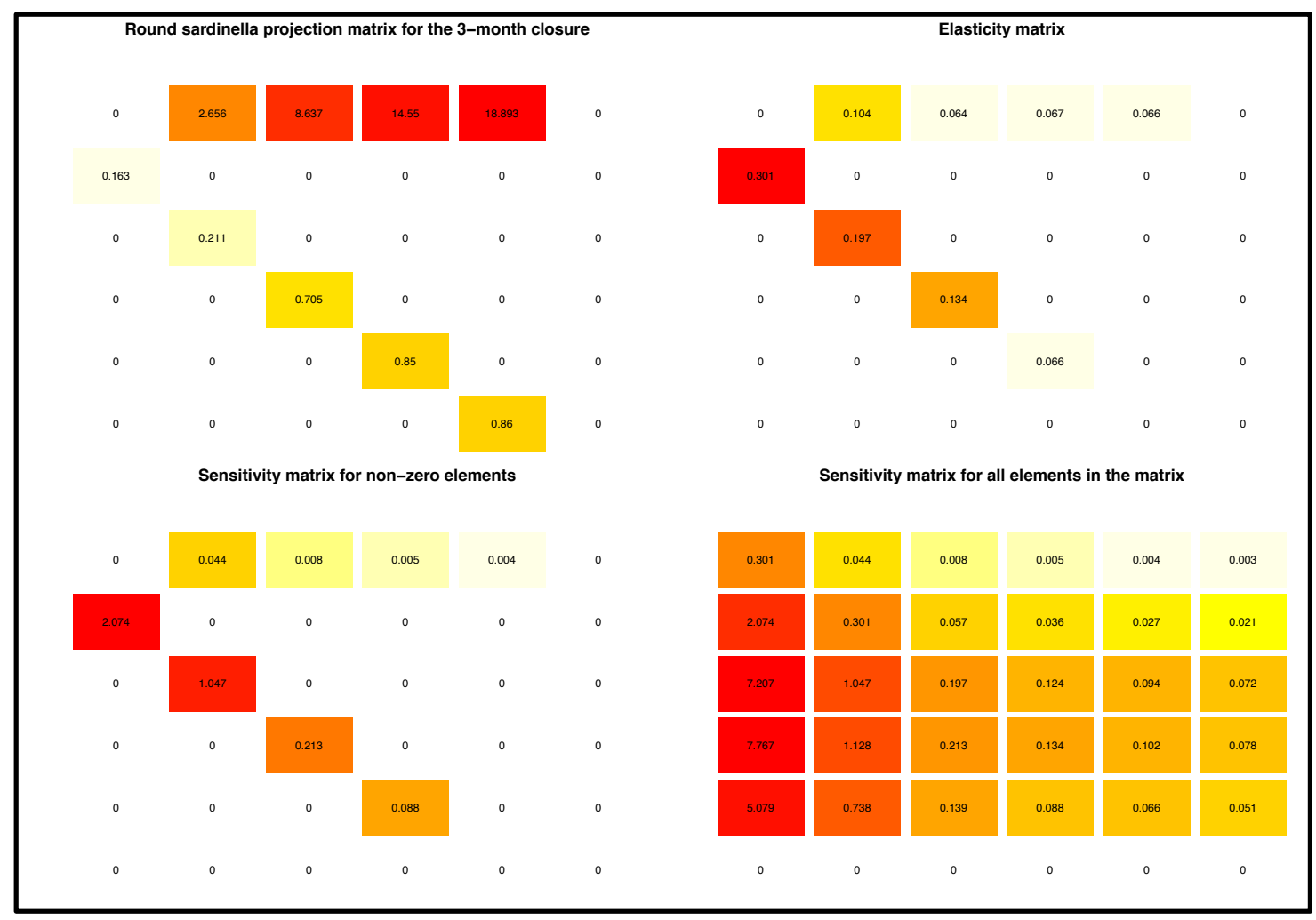

Fig. A44. Sardinella aurita projection matrix with the sensitivities and elasticities for the fertility and survival rates of the fish for the 3-month closure without any gear restrictions. 


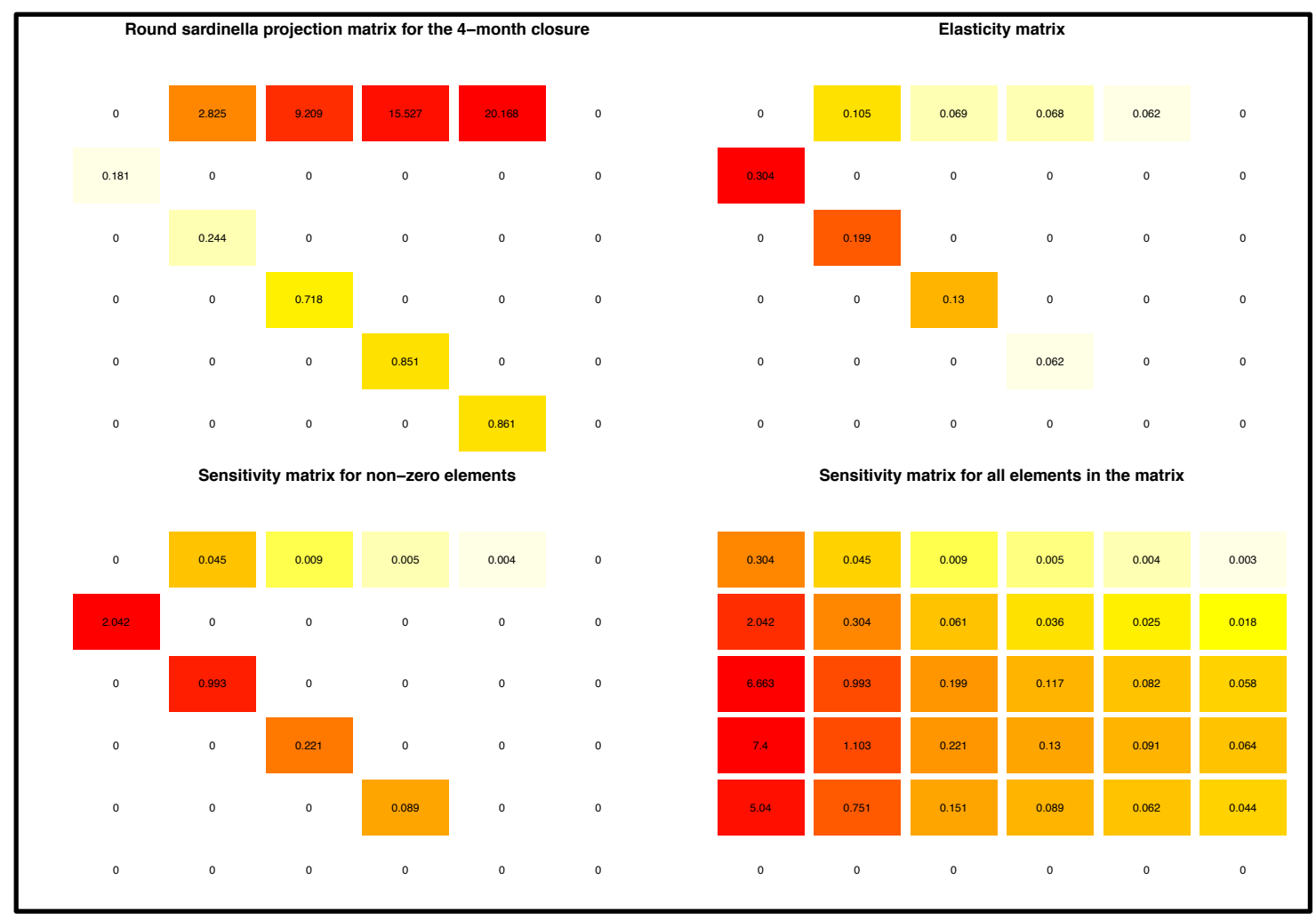

Fig. A45. Sardinella aurita projection matrix with the sensitivities and elasticities for the fertility and survival rates of the fish for the 4-month closure without any gear restrictions. 


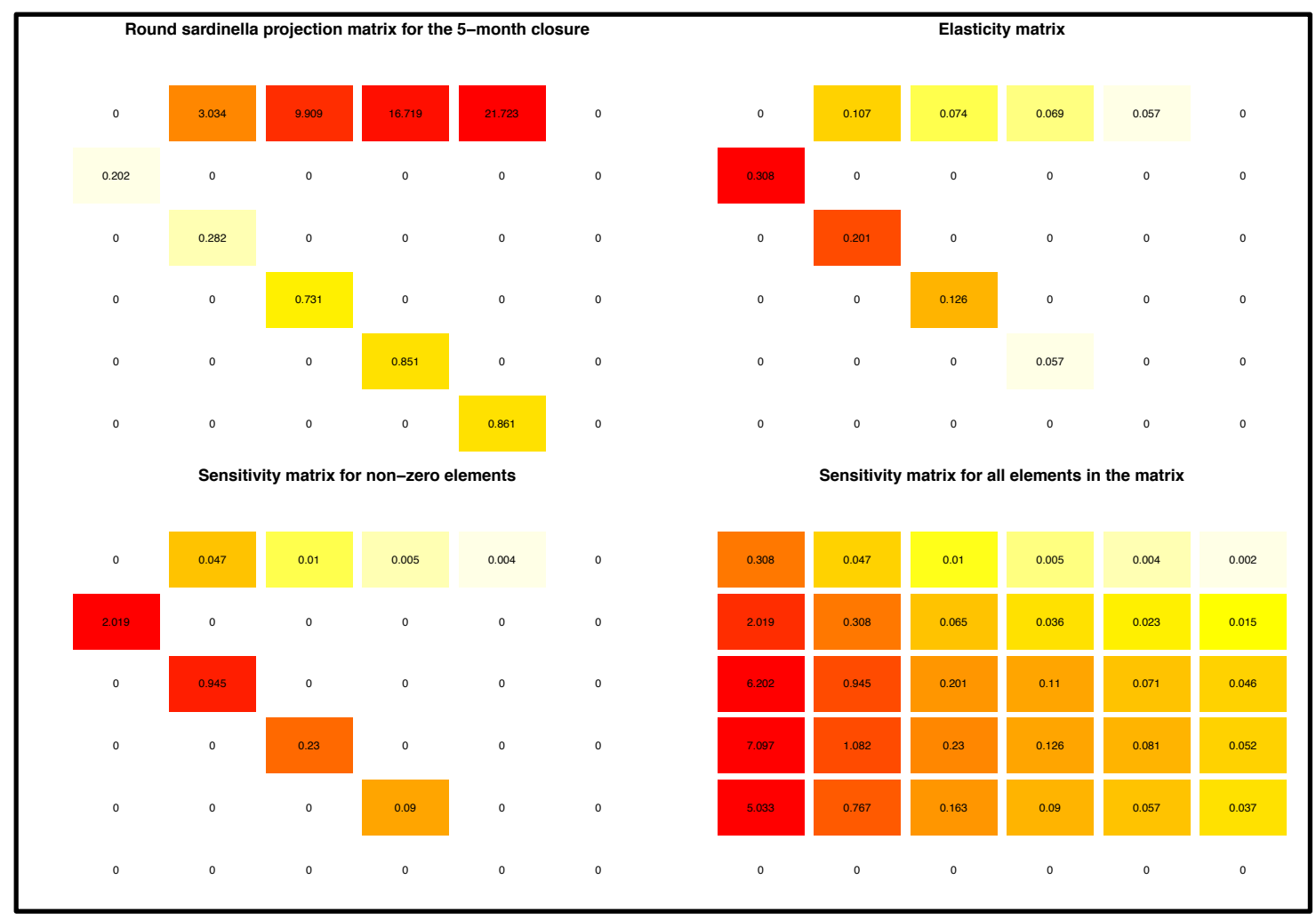

Fig. A46. Sardinella aurita projection matrix with the sensitivities and elasticities for the fertility and survival rates of the fish for the 5-month closure without any gear restrictions. 


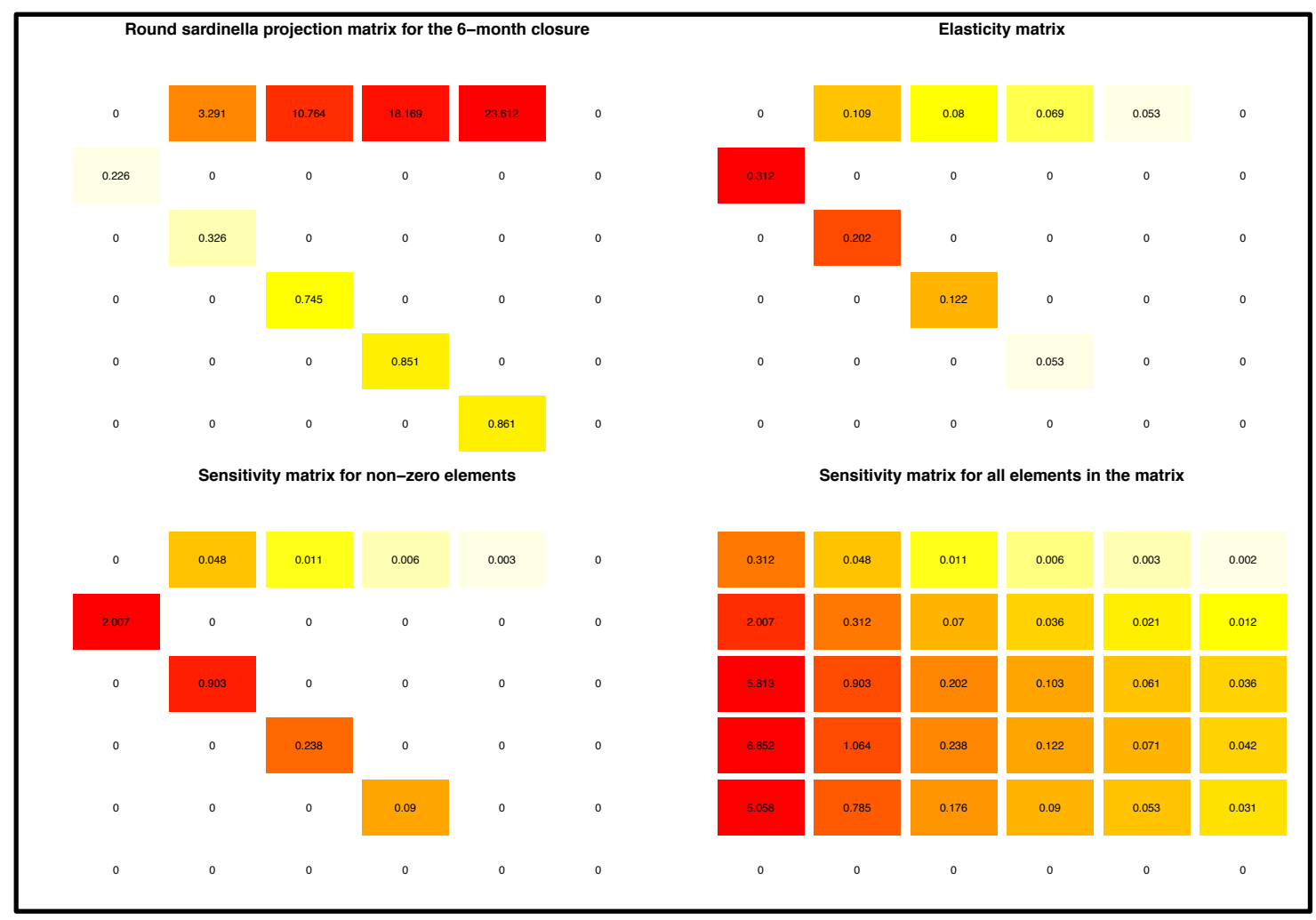

Fig. A47. Sardinella aurita projection matrix with the sensitivities and elasticities for the fertility and survival rates of the fish for the 6-month closure without any gear restrictions. 


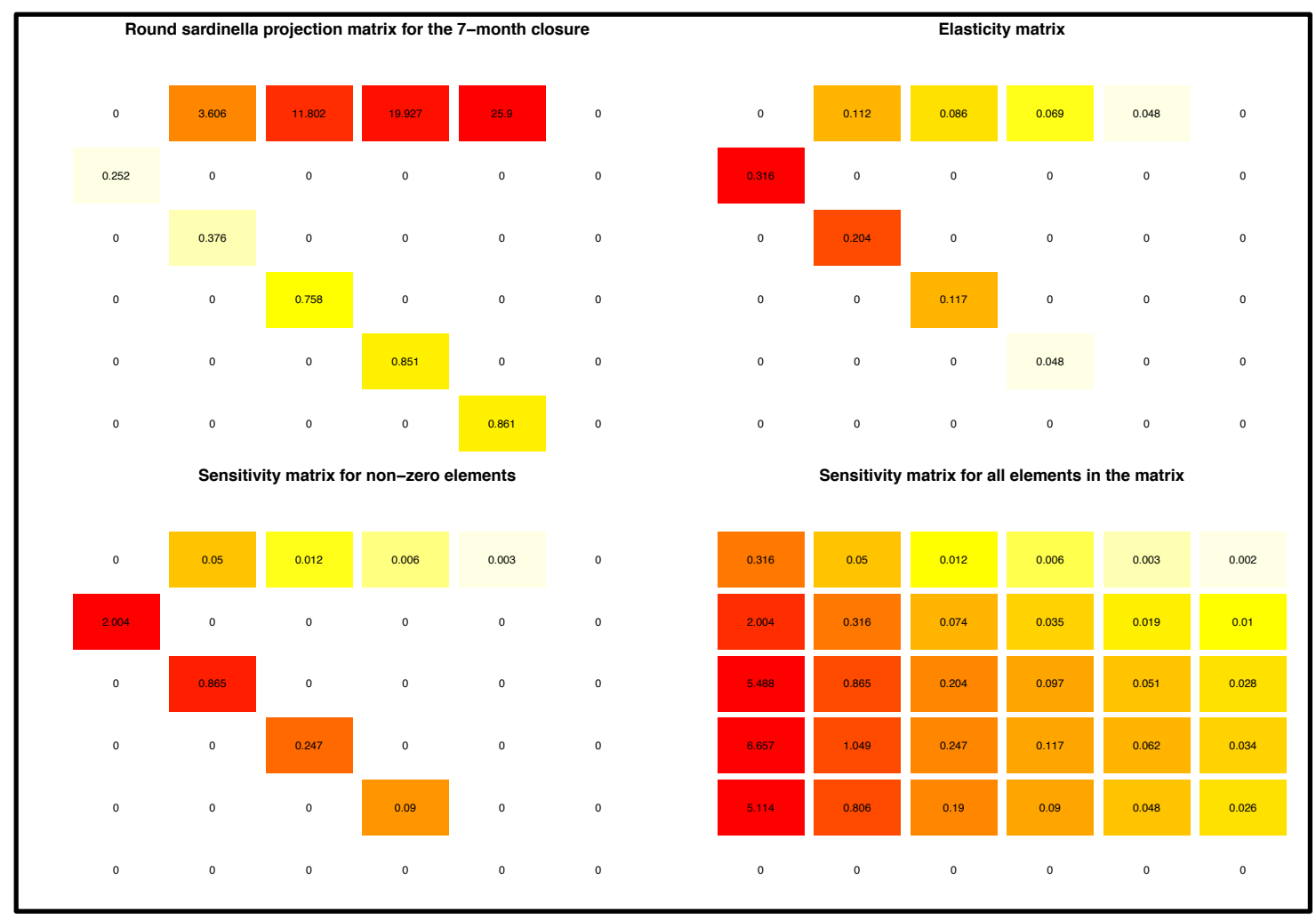

Fig. A48. Sardinella aurita projection matrix with the sensitivities and elasticities for the fertility and survival rates of the fish for the 7-month closure without any gear restrictions. 


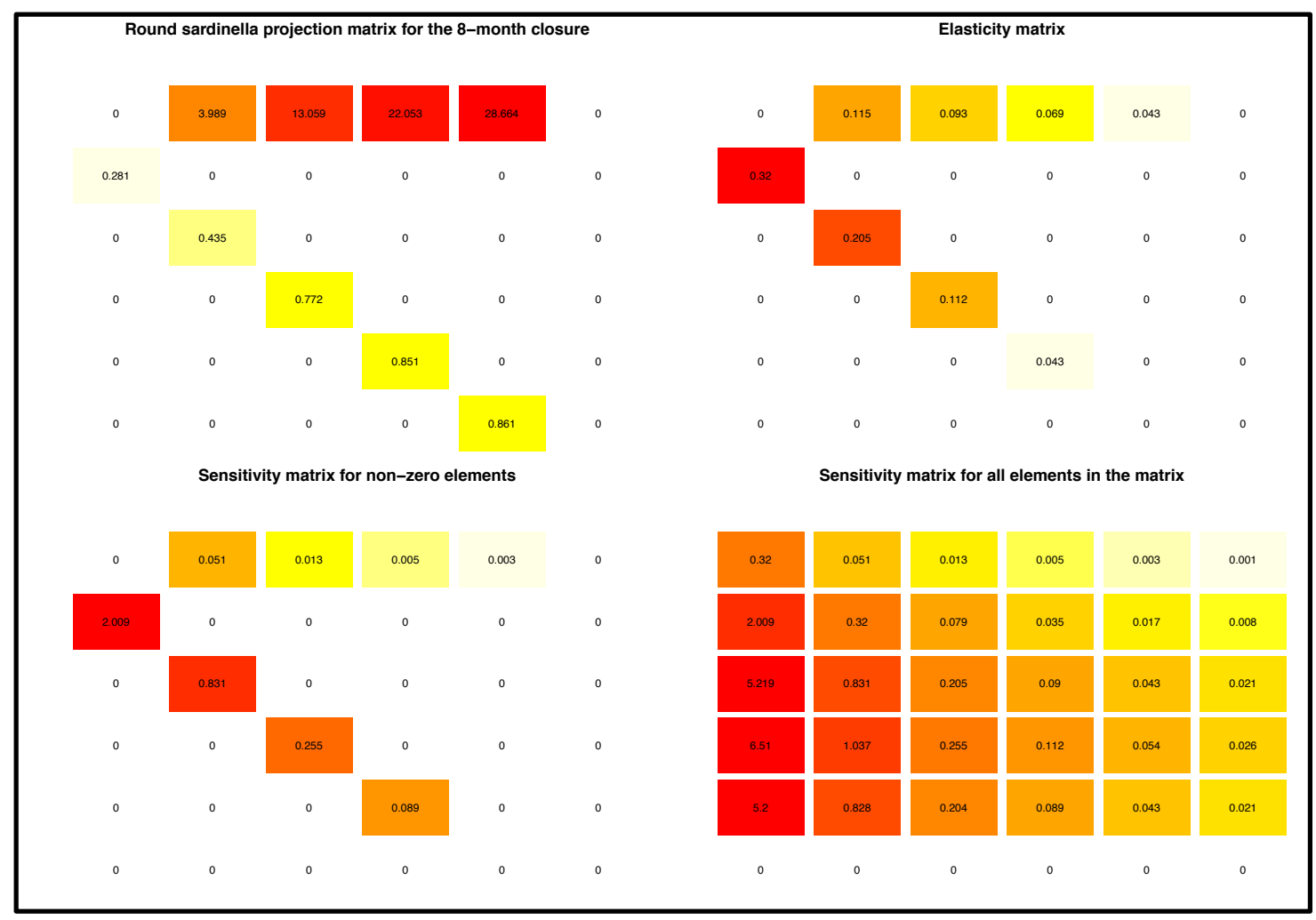

Fig. A49. Sardinella aurita projection matrix with the sensitivities and elasticities for the fertility and survival rates of the fish for the 8-month closure without any gear restrictions. 


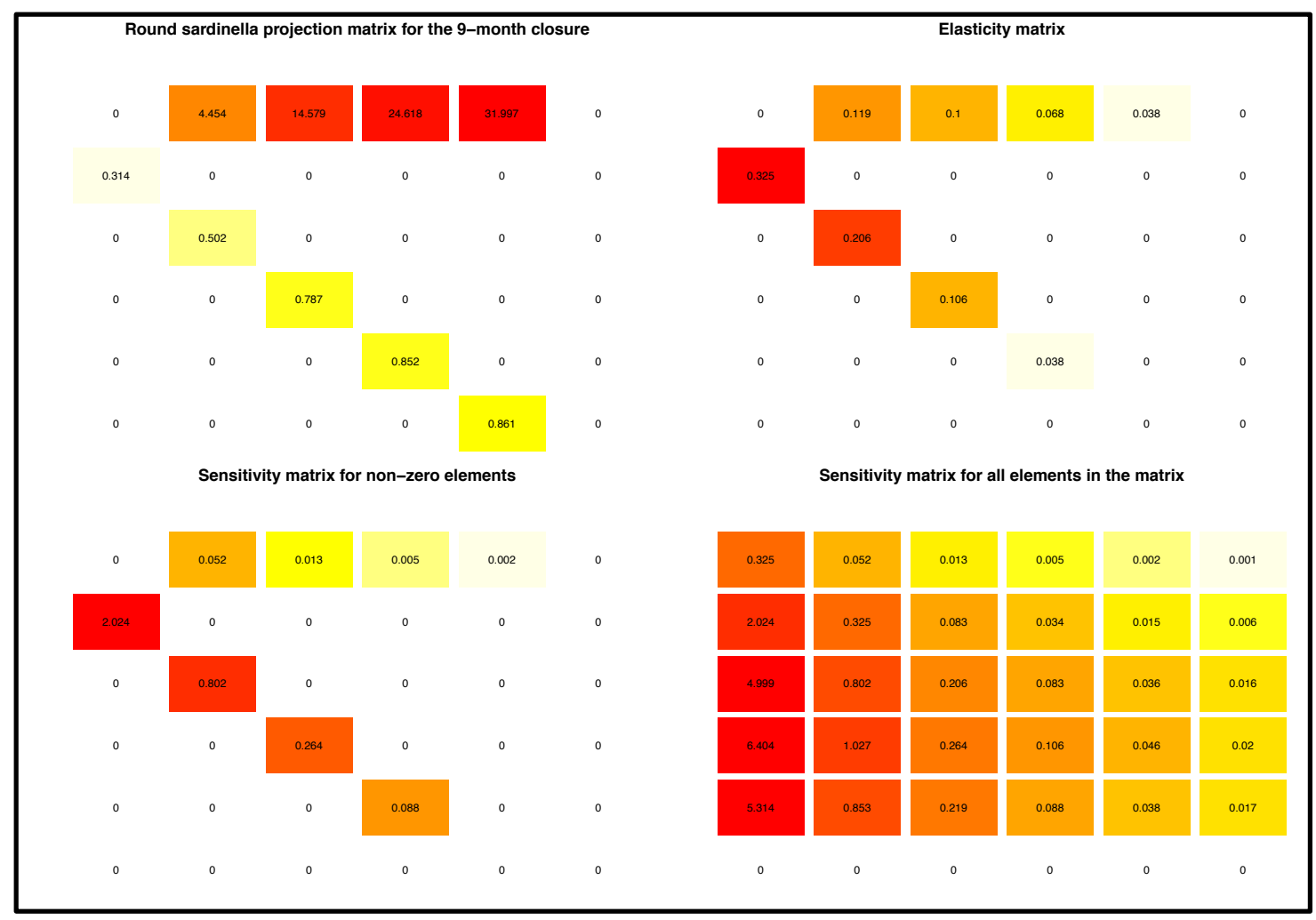

Fig. A50. Sardinella aurita projection matrix with the sensitivities and elasticities for the fertility and survival rates of the fish for the 9-month closure without any gear restrictions. 


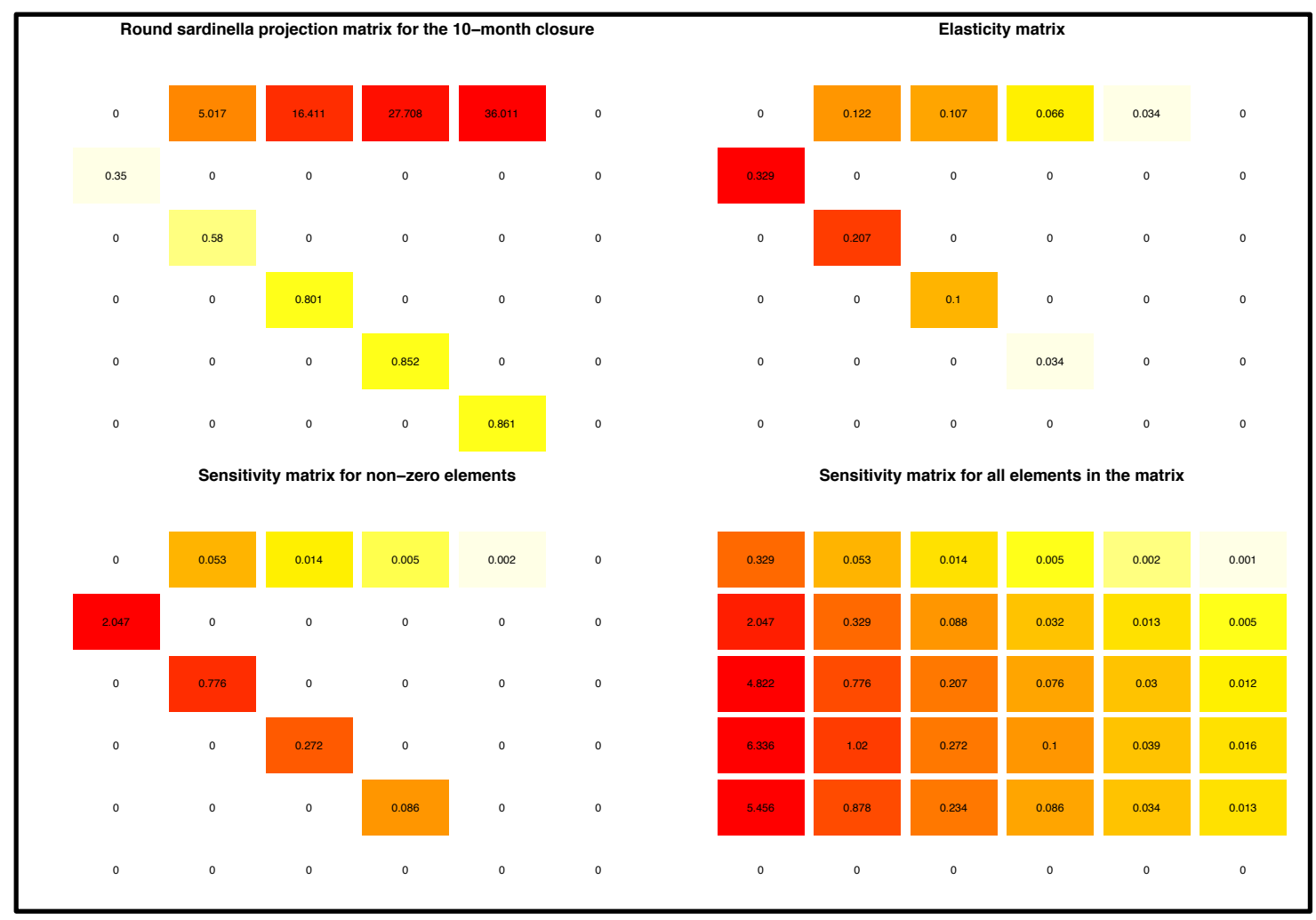

Fig. A51. Sardinella aurita projection matrix with the sensitivities and elasticities for the fertility and survival rates of the fish for the 10-month closure without any gear restrictions. 


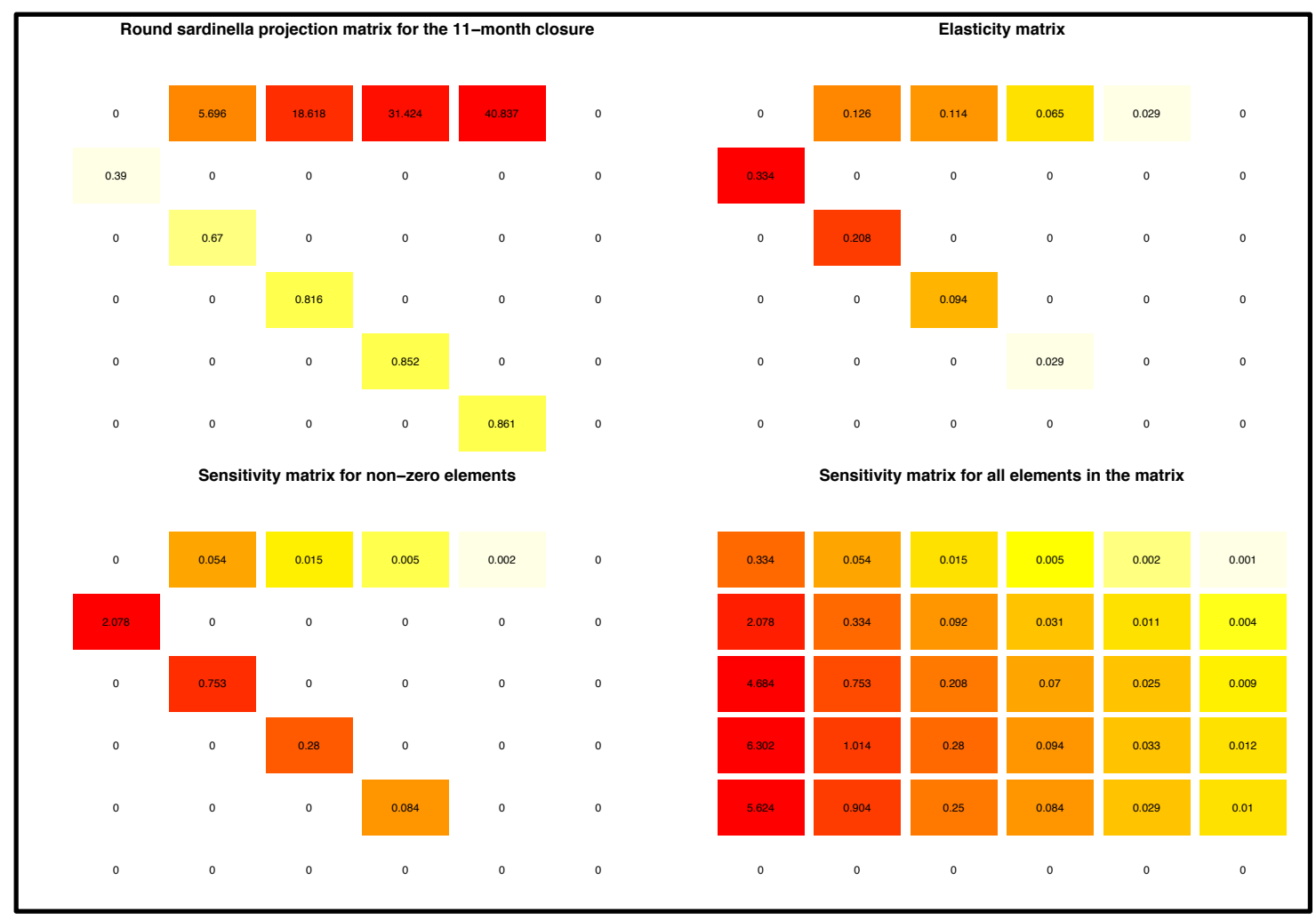

Fig. A52. Sardinella aurita projection matrix with the sensitivities and elasticities for the fertility and survival rates of the fish for the 11-month closure without any gear restrictions. 


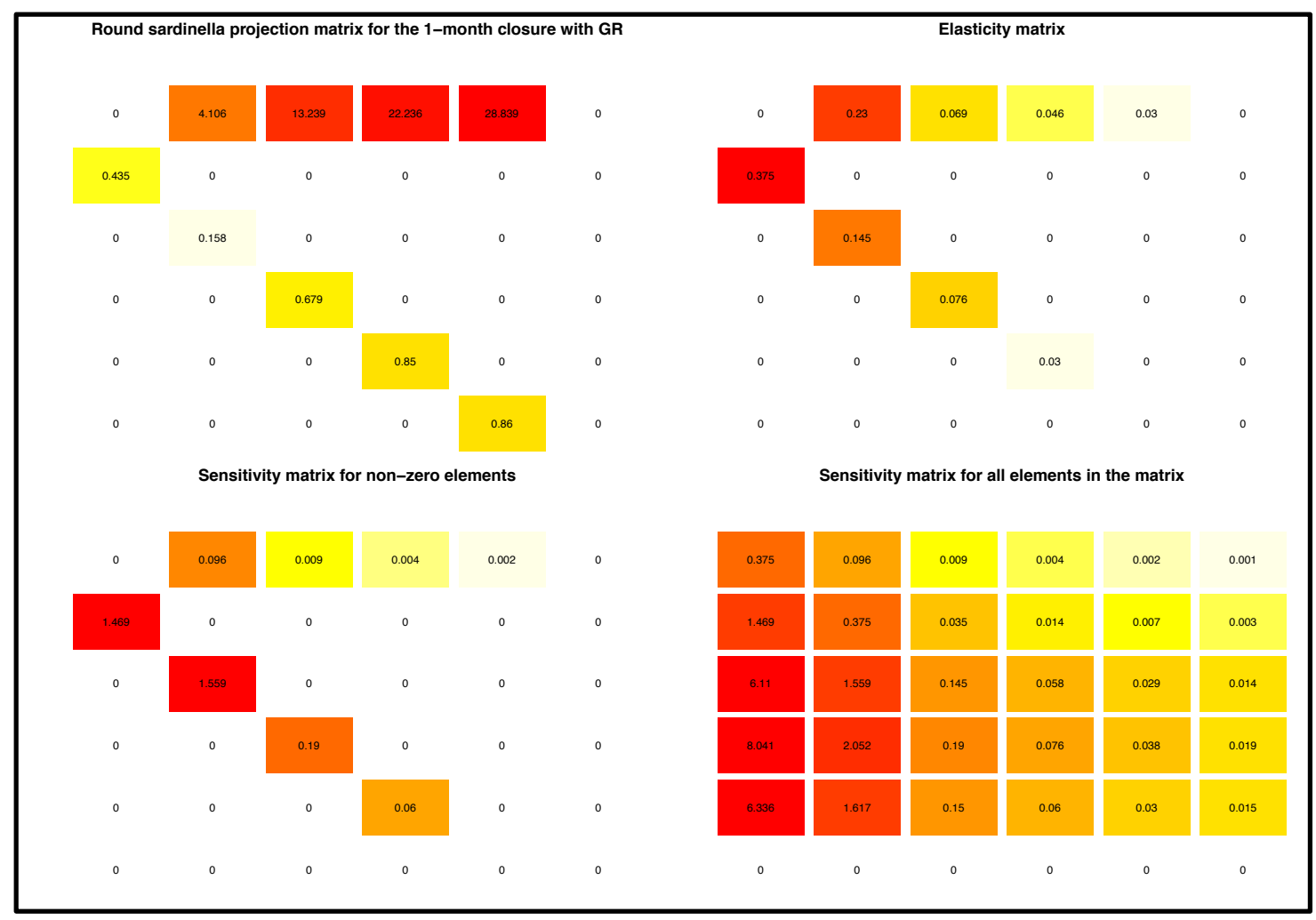

Fig. A53. Sardinella aurita projection matrix with the sensitivities and elasticities for the fertility and survival rates of the fish for the 1-month closure with gear restrictions. 


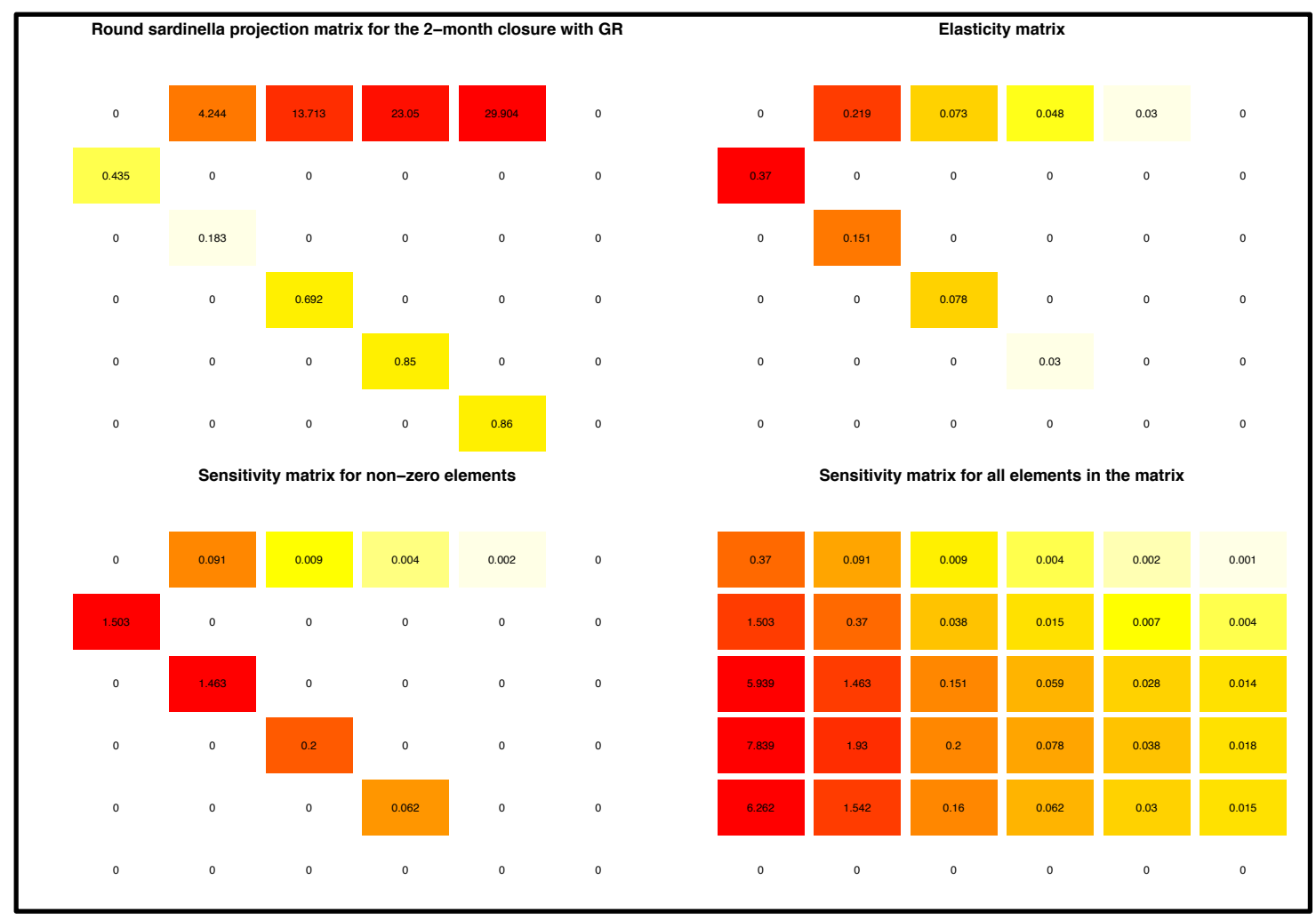

Fig. A54. Sardinella aurita projection matrix with the sensitivities and elasticities for the fertility and survival rates of the fish for the 2-month closure with gear restrictions. 


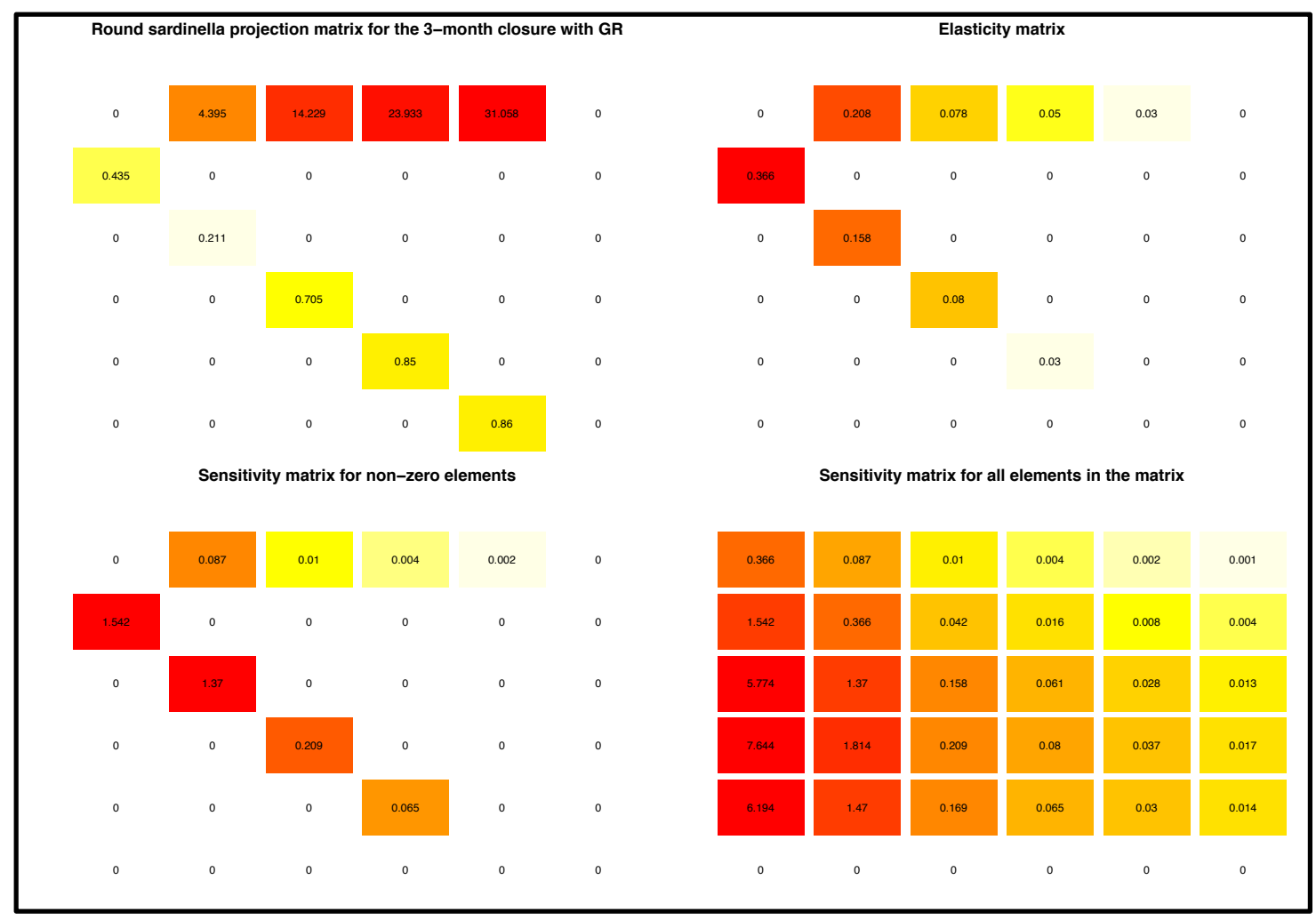

Fig. A55. Sardinella aurita projection matrix with the sensitivities and elasticities for the fertility and survival rates of the fish for the 3-month closure with gear restrictions. 


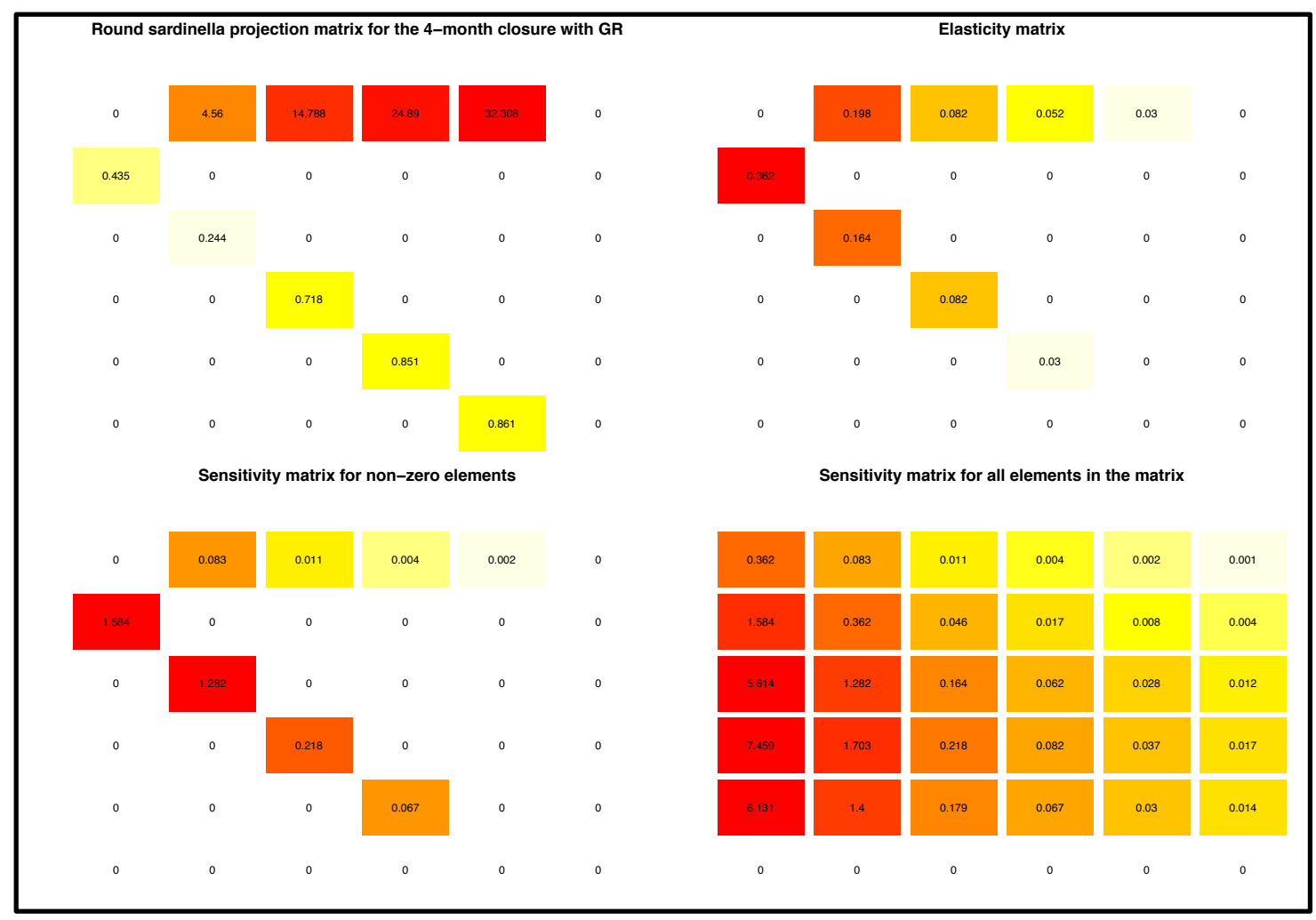

Fig. A56. Sardinella aurita projection matrix with the sensitivities and elasticities for the fertility and survival rates of the fish for the 4-month closure with gear restrictions. 


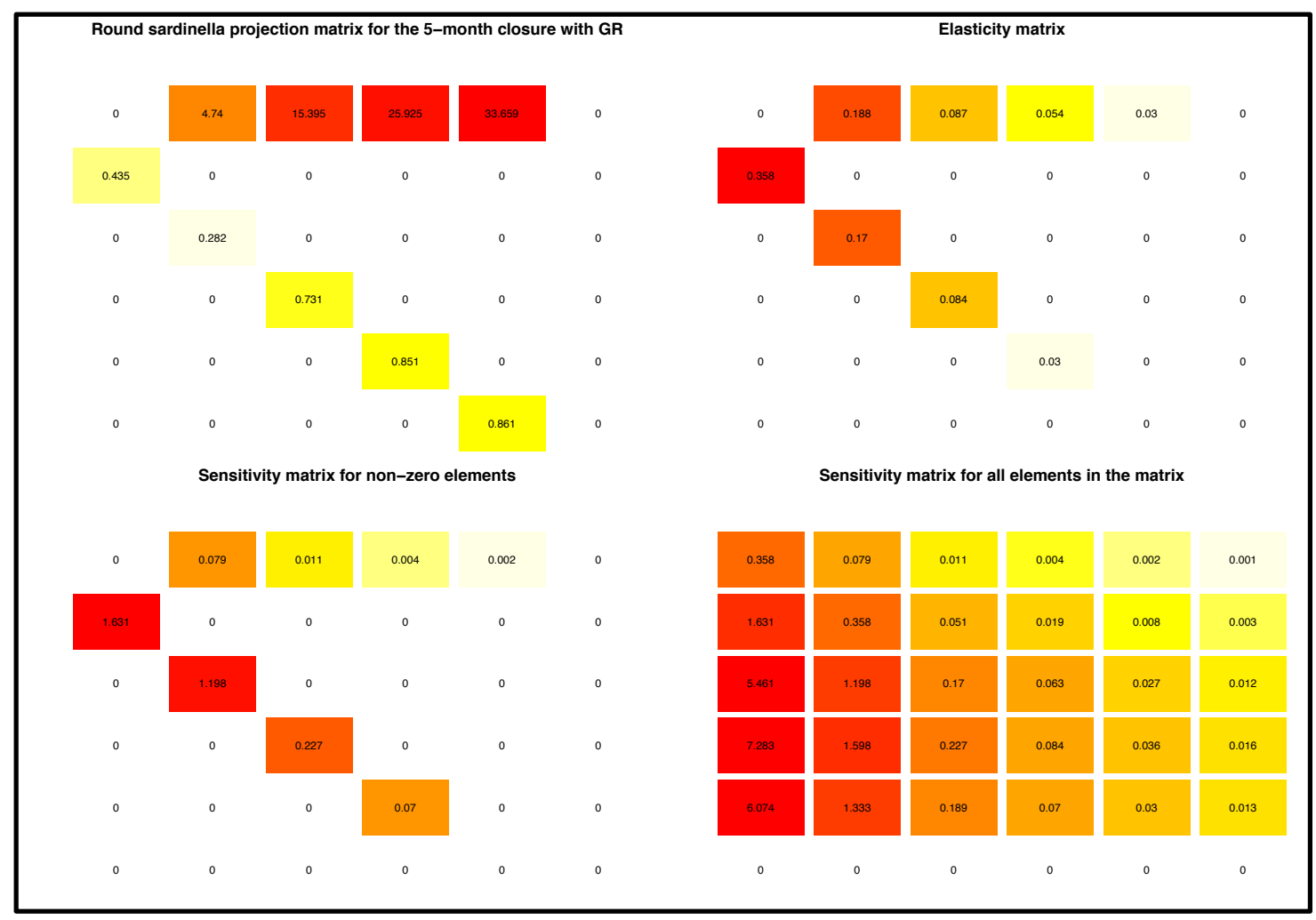

Fig. A57. Sardinella aurita projection matrix with the sensitivities and elasticities for the fertility and survival rates of the fish for the 5-month closure with gear restrictions. 


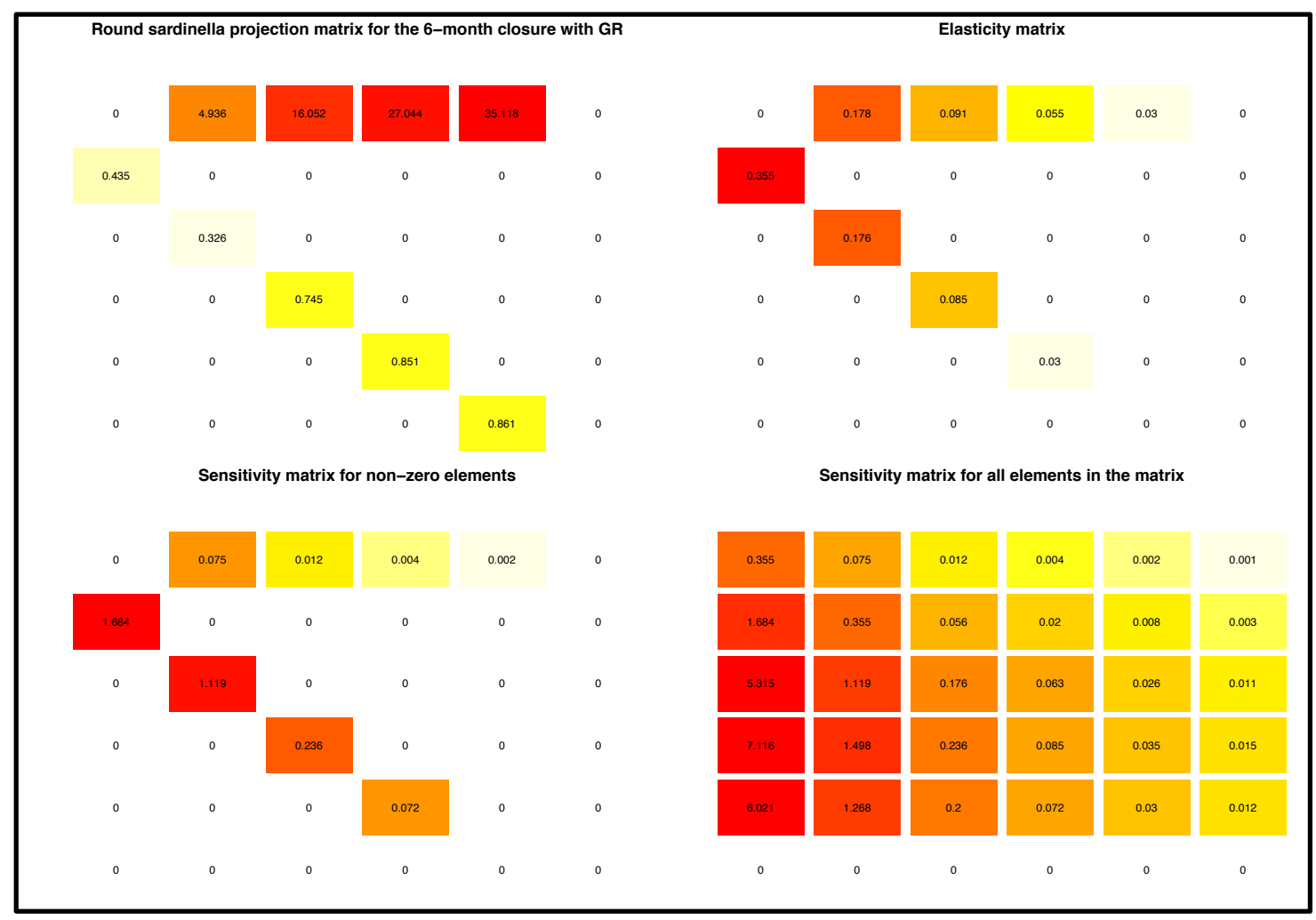

Fig. A58. Sardinella aurita projection matrix with the sensitivities and elasticities for the fertility and survival rates of the fish for the 6-month closure with gear restrictions. 


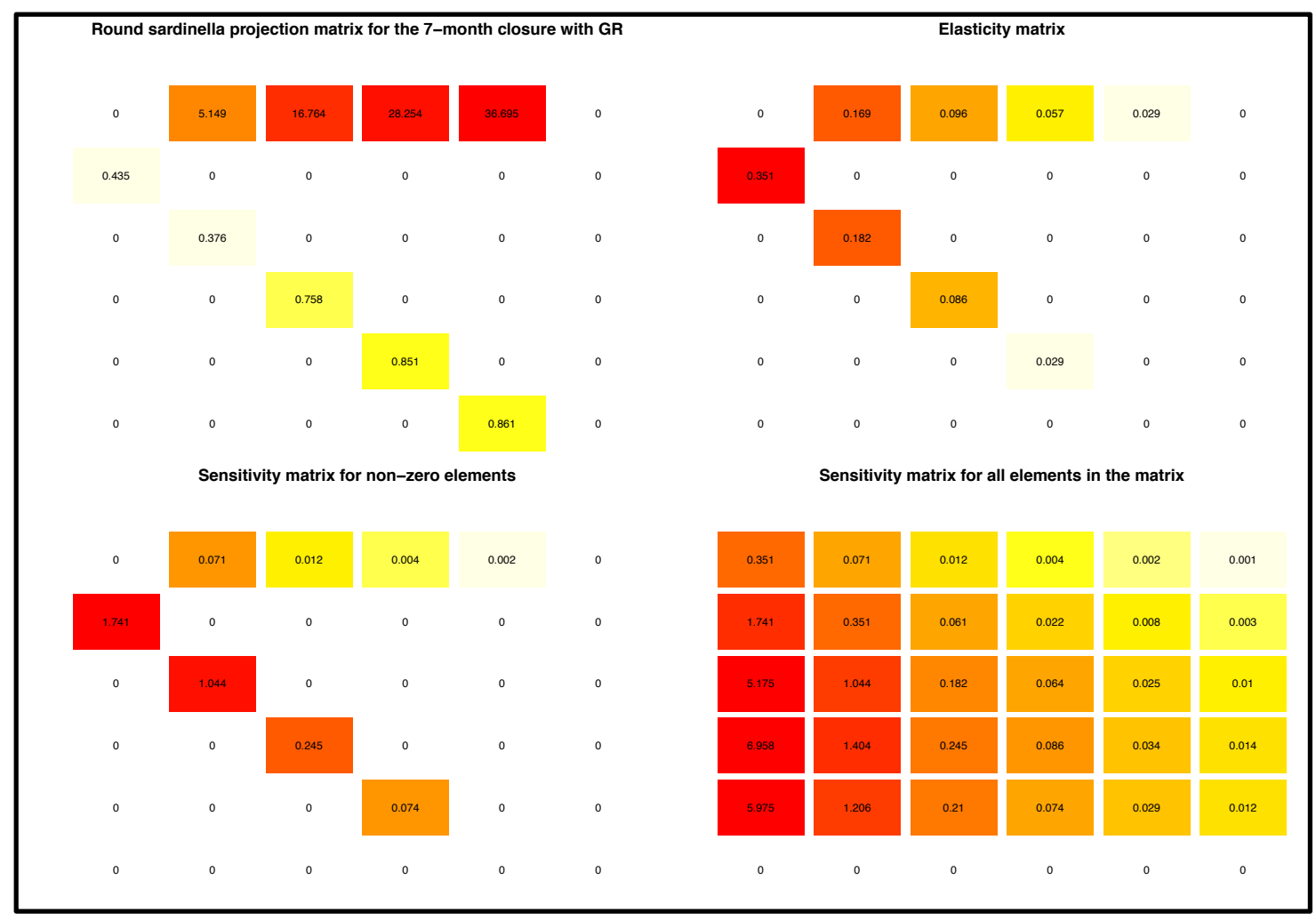

Fig. A59. Sardinella aurita projection matrix with the sensitivities and elasticities for the fertility and survival rates of the fish for the 7-month closure with gear restrictions. 


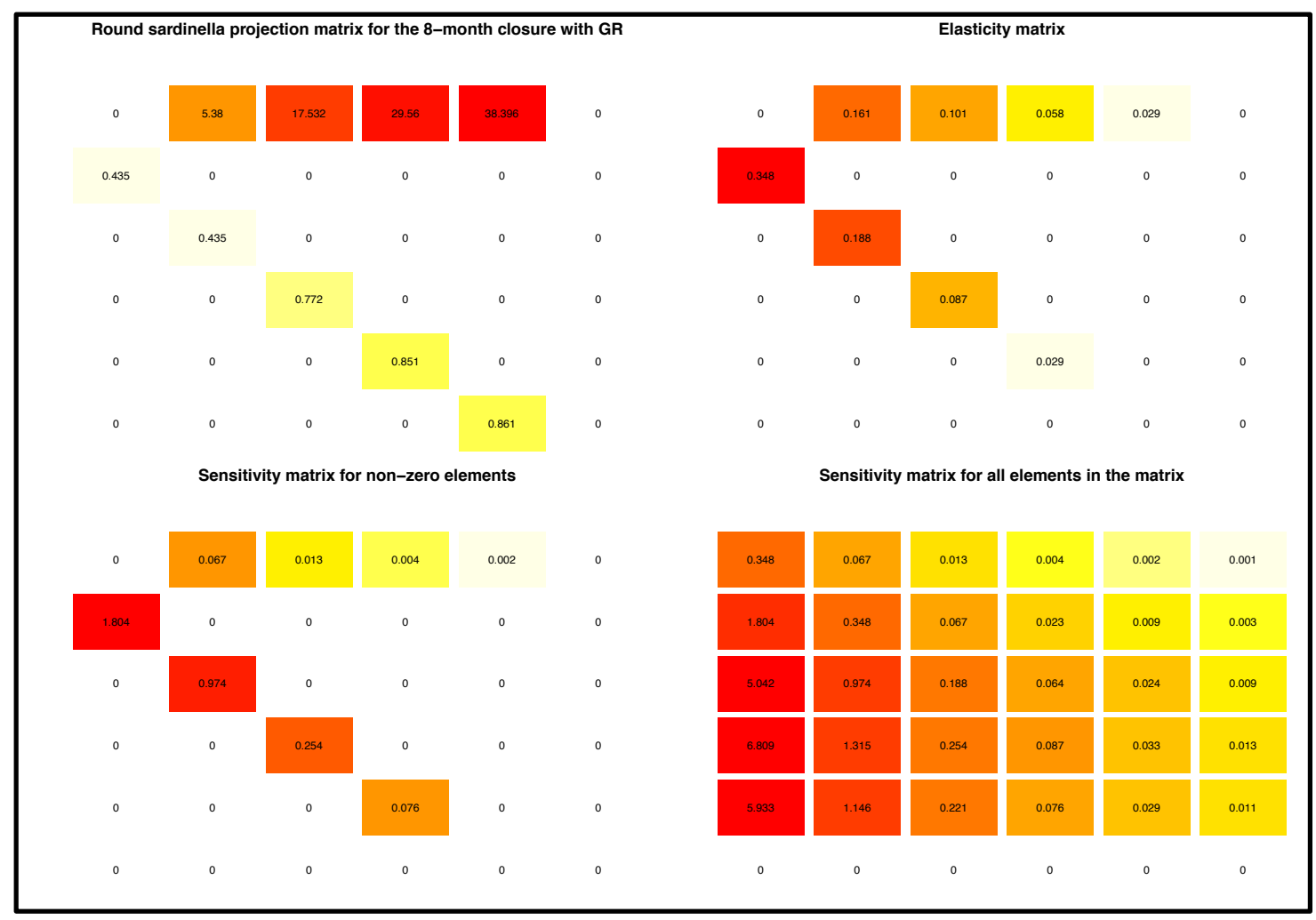

Fig. A60. Sardinella aurita projection matrix with the sensitivities and elasticities for the fertility and survival rates of the fish for the 8-month closure with gear restrictions. 


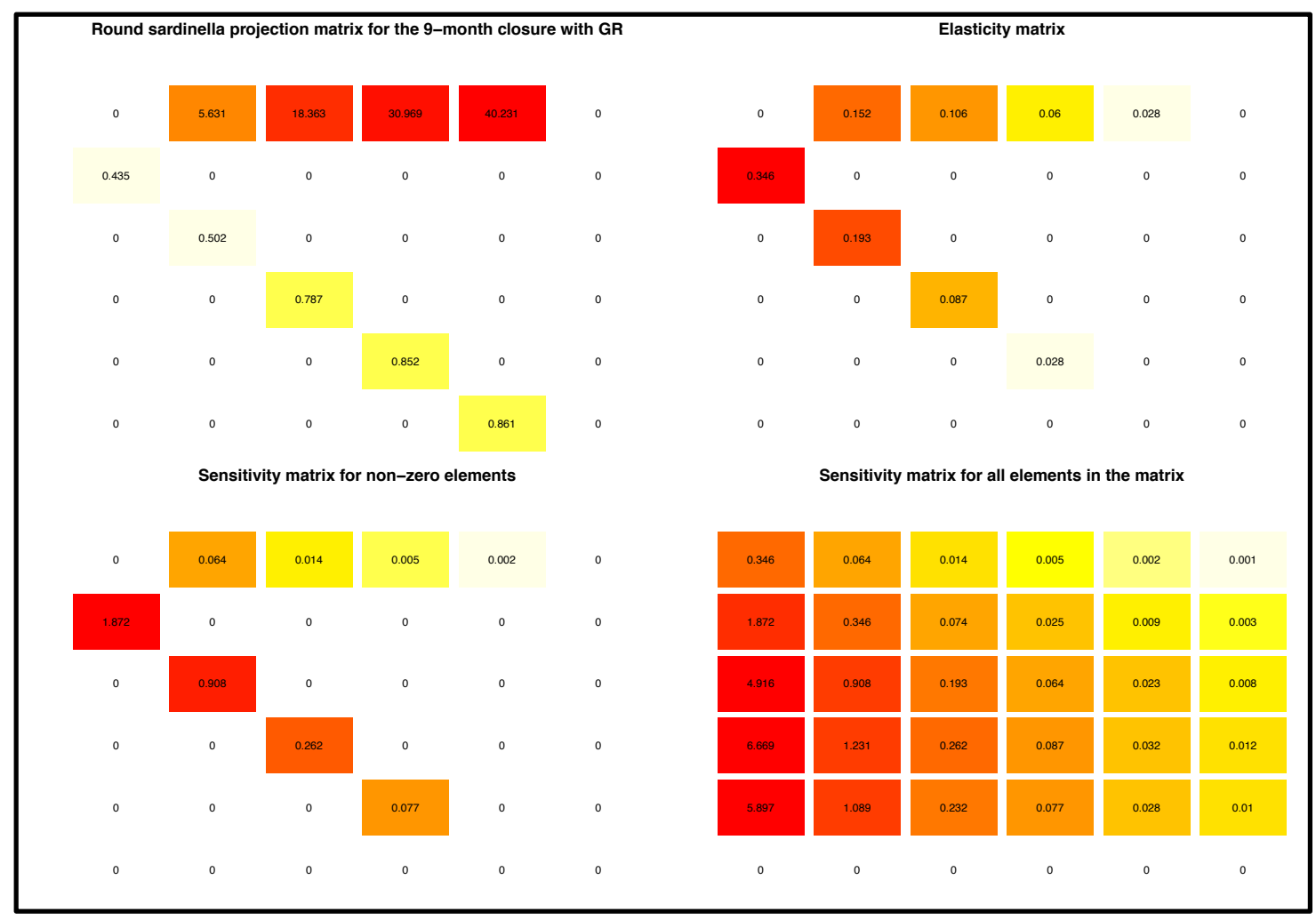

Fig. A61. Sardinella aurita projection matrix with the sensitivities and elasticities for the fertility and survival rates of the fish for the 9-month closure with gear restrictions. 


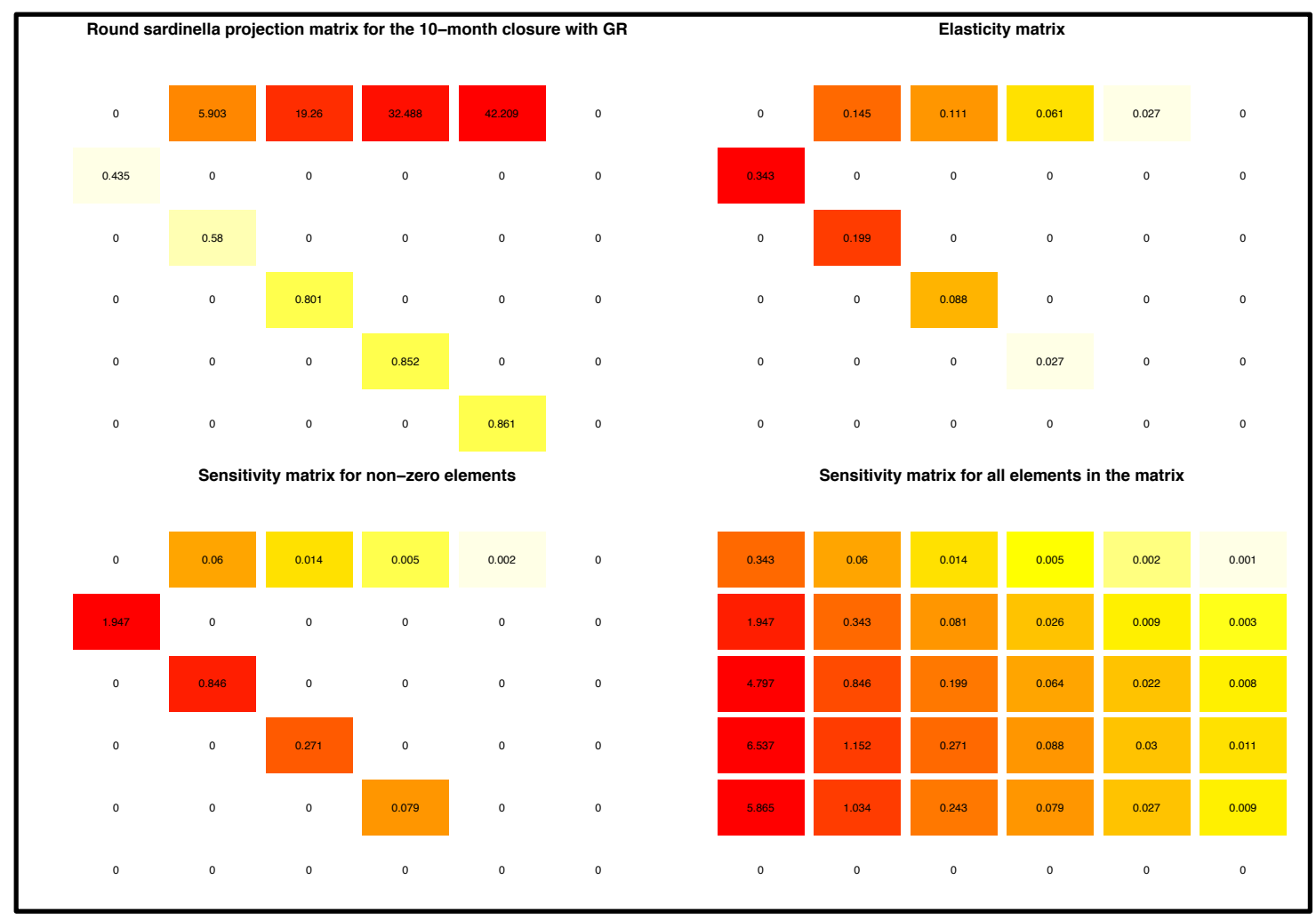

Fig. A62. Sardinella aurita projection matrix with the sensitivities and elasticities for the fertility and survival rates of the fish for the 10-month closure with gear restrictions. 


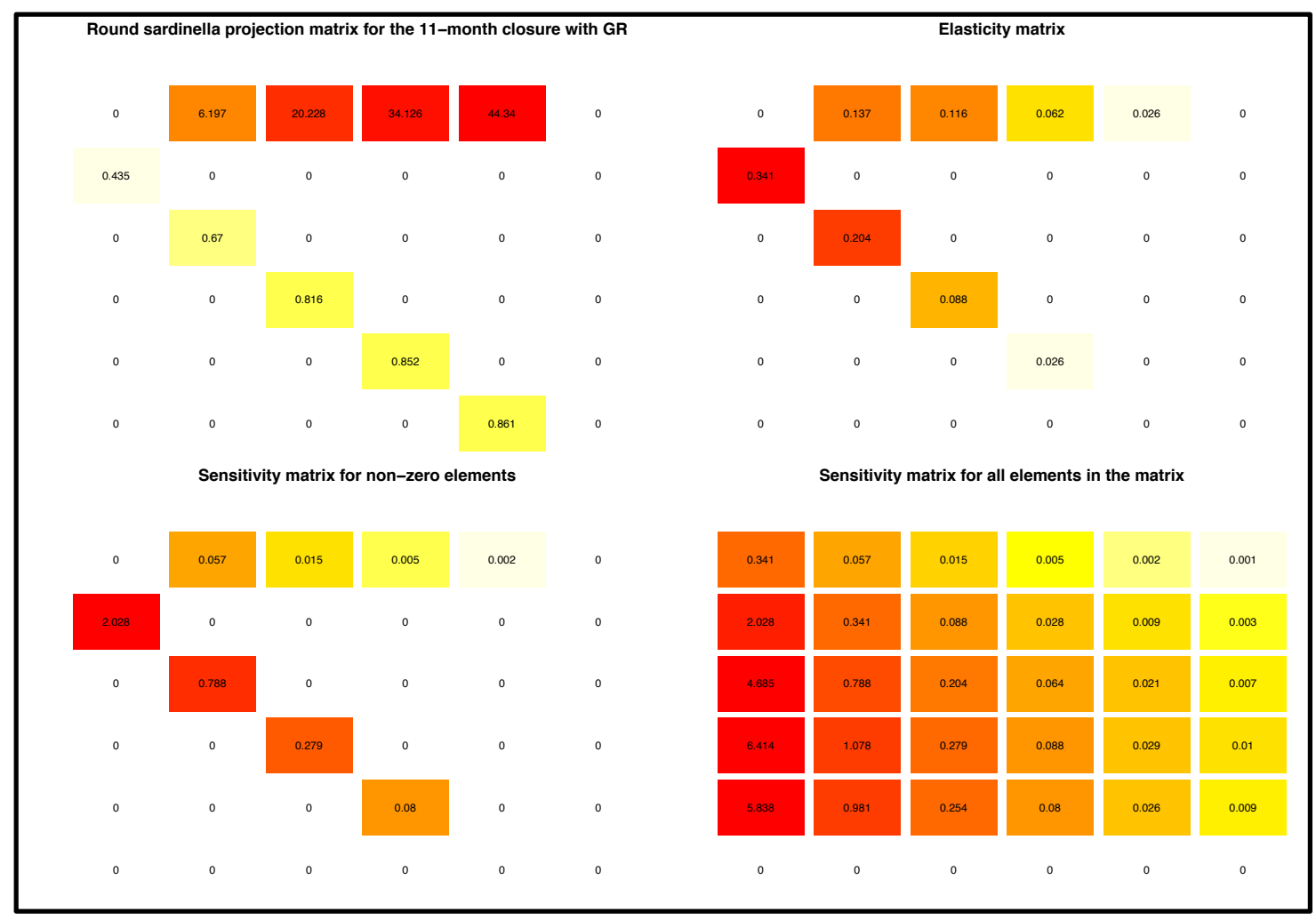

Fig. A63. Sardinella aurita projection matrix with the sensitivities and elasticities for the fertility and survival rates of the fish for the 11-month closure with gear restrictions. 